Aus dem Department für Nutzpflanzenwissenschaften

- Abteilung Graslandwissenschaft -

der Georg-August-Universität Göttingen

\title{
Management, methods and attitudes concerning grassland farming in Northern Germany
}

\author{
Dissertation \\ zur Erlangung des Doktorgrades \\ der Fakultät für Agrarwissenschaften \\ der Georg-August-Universität Göttingen
}

vorgelegt von

Verena Hammes

geboren in Damme

Göttingen, Dezember 2016 
D 7

1. Referent: Prof. Dr. Johannes Isselstein

2. Korreferent: Prof. Dr. Nicole Wrage-Mönnig

Tag der mündlichen Prüfung: 3. Februar 2017 
"Die dümmsten Schlächter wählen ihre Schafe ... nee ...das ging anders...

Die dümmsten Schafe wählen ihre Kälber ... nee... Die dümmsten Schafe sterben im Schlafe ... nee ... Ach, egal. - Oscar Wild“ 


\section{Table of Contents}

\section{CHAPTER 1}

Introduction

\section{CHAPTER 2}

The attitude of grassland farmers towards nature conservation and agri-environment measures - A survey-based analysis

\section{CHAPTER 3}

I know what you fed last summer - Tracing back the dietary

proportion of maize in cattle diet with ${ }^{13} \mathrm{C}$

\section{$\underline{\text { CHAPTER } 4}$}

How an intensification of extensive grasslands on sandy soils

affects yield, forage quality and other ecosystem services

\section{CHAPTER 5}

Synthesis

\section{CHAPTER 6}

Summary

\section{CHAPTER 7}

Appendix 


\section{Abbreviations}

$\delta^{13} \mathrm{C} \quad$ Isotopic signature of stable isotopes of carbon $\left({ }^{13} \mathrm{C}:{ }^{12} \mathrm{C}\right)$

AEM Agri-environment measure

AMT Annual mean temperature

AUM Agrarumweltmaßnahme

CAP Common Agricultural Policy

CDC Climate Data Center

DH Diepholz

DWD Deutscher Wetterdienst (German Weather Service)

EC European Commission

FL Fläming

GfE Gesellschaft für Ernährungsphysiologie (German Society of Nutrition Physiology)

HK Heidekreis

Lon Longitude

LU Livestock unit

NaLaMa-nT Nachhaltiges Landmanagement im norddeutschen Tiefland (Sustainable land management in the North German Plain)

NEP North European Plain

NGP North German Plain

NUE Nitrogen Use Efficiency

OS Oder-Spree

PGI Intensive permanent grassland

PGM Moderate permanent grassland

UE Uelzen

vegT Mean temperature during vegetation period

vegP Precipitation during vegetation period 
CHAPTER 1

\author{
Introduction
}




\subsection{Grassland farming}

In grassland farming systems the harvested or grazed biomass (grass, herbs, and legumes) is the basic crop taken from the agricultural land. Herbage from grassland is mainly used in cattle production systems (dairy and beef) but also provides the basis for keeping sheep, goats, and horses. Grassland farming includes the permanent and temporary grassland that is incorporated in a crop rotation system on arable land. Permanent pasture is defined by the European Commission as "land used to grow grasses or other herbaceous forage naturally (self-seeded) or through cultivation (sown) and that has not been included in the crop rotation of the holding for five years or longer" (Commission Regulation (EC) No 796/2004).

\subsection{Potentials and challenges concerning grassland farming in Europe}

During the last decade social awareness of the multifunctionality of grassland and especially permanent grasslands has increased (Jeangros and Thomet, 2004; Lehmann and Hediger, 2004; Gibon, 2005; Sanderson et al., 2007). Grasslands provide several ecosystem services like biodiversity and wildlife protection, carbon sequestration, water purification, nutrient retention as well as social benefits like recreation (e.g. Hopkins et al., 2002; Isselstein and Kayser, 2014).

This multifunctionality, however, strongly depends on the intensity of the grassland management and on environmental conditions. Although agriculture in Europe is strongly supported by governmental subsidies, the agricultural production systems have to adjust their production methods and management to recent global market and price fluctuation trends to stay profitable. During the last two decades the utilization of grassland in Europe has changed considerably. In the last twenty years the area of grassland has decreased in most European countries as well as the number of cattle (EUROSTAT). In Germany, cattle number decreased by more than $35 \%$ and the number of sheep by more than $11 \%$ from 1990 to 2015.

This development was partly caused by a more intensive dairy production which represents the most profitable way of grassland utilization (Isselstein et al. 2005). There is an on-going trend to increasing milk yields per cow which requires high energy contents in the feed - this can be provided by intensive permanent grassland management, ley grass and silage maize (e.g. Taube and Conijn, 2007). Maize is comparably easy to cultivate at reasonable costs. In Germany, the area that is cultivated with maize and other non-grass feed for dairy production has increased during the last half century (Offermann 
et al., 2010; Reheul et al. 2015) often at the expense of permanent grassland. This trend is going to continue or even increase with the end of the milk quota in 2015 (BfNGrünlandreport, 2014). However, it is the permanent grassland that provides a wider range of ecosystem services than ley grass or arable farming.

To foster a more sustainable forage production the new Common Agricultural Policy (2014-2020), enacted by the European Union in 2013, developed new "Greening" guidelines to promote the preservation of permanent grassland. However, these new guidelines seem to be not as effective as intended (Pe'er et al., 2014) and miss their conservation targets, especially when it comes to preserving permanent grassland.

In spite of the on-going land use intensification and the increasing cultivation of high energy crops, forage from grassland is still regarded as rather cost-efficient compared to maize and other concentrates and is often still the basis of cattle production systems in Europe. These forage production systems, however, differ on a regional scale. To support an overall preservation of a sustainable grassland management it is important to investigate grassland farming systems on a regional scale concerning farm structures and regional conservation goals.

\subsection{Grassland farming in Northern Germany}

In northern Germany grassland covers 20 to $30 \%$ of the agricultural land (Statistisches Bundesamt 2008; Smit et al. 2008). The percentage slightly differs among the federal states of Germany (Tab. 1.1).

Tab. 1.1: Area of agricultural land and grassland in Germany (Source: German Federal Statistical Office (Destatis), Subject-matter series 3, 2014).

\begin{tabular}{lrrr}
\hline Federal State & $\begin{array}{r}\text { Agricultural land } \\
\text { (ha) }\end{array}$ & $\begin{array}{r}\text { Grassland } \\
\text { (ha) }\end{array}$ & $\begin{array}{r}\text { Grassland } \\
\text { (\% of agricultural land) }\end{array}$ \\
\hline Baden-Württemberg & 1422.0 & 549.3 & 38.6 \\
Bavaria & 3141.2 & 1052.9 & 33.5 \\
Berlin & 2.0 & 0.7 & 35.0 \\
Brandenburg & 1313.6 & 281.2 & 21.4 \\
Bremen & 8.5 & 6.7 & 78.8 \\
Hamburg & 14.4 & 6.7 & 46.5 \\
Hesse & 768.0 & 282.9 & 36.8 \\
Lower Saxony & 2625.9 & 719.3 & 27.4 \\
Mecklenburg-Western & 1340.3 & 261.8 & 19.5 \\
Pomerania & & & \\
North Rhine-Westphalia & 1460.1 & 389.0 & 26.6 \\
Rhineland-Palatinate & 703.5 & 222.7 & 31.7 \\
Saarland & 77.5 & 39.7 & 51.2 \\
Sachsen & 904.2 & 183.7 & 20.3
\end{tabular}




\begin{tabular}{lrrr} 
Saxony-Anhalt & 1169.1 & 169.5 & 14.5 \\
Schleswig Holstein & 993.6 & 318.3 & 32.0 \\
Thuringia & 781.0 & 166.2 & 21.3 \\
& & & \\
Germany total & 16724.8 & 4650.7 & 27.8 \\
\hline
\end{tabular}

The efficiency of a multifunctional grassland depends on well balanced goals. However, the more services are demanded from grassland the more likely are goal conflicts and trade-offs (Isselstein and Kayser, 2012; Isselstein and Kayser, 2014).

The frame conditions for grassland management can change due to agricultural political targets, market processes, cost structures, technological process and climate change on a regional scale. These factors can intensify goal conflicts and compromise sustainable, multifunctional grassland farming (Dabbert and Krimly, 2004; Soussana and Lüscher, 2007; Peeters, 2008). Therefore, it makes sense to evaluate grassland farming and grassland management practices on a regional and on a farm scale in order to development sophisticated adaption strategies for a sustainable grassland management.

An assessment of grassland farming systems by quantitative indicators for the sustainability of production system can also be helpful (Taube and Wachendorf, 2004, van Passel et al., 2006, Treyse et al 2008). This approach would include investigations on productivity and nutrient fluxes on different levels and in different production systems (Schröder et al., 2003; Rotz et al., 2005).

Furthermore, climate change is supposed to change the productivity of grassland (yields and nutritional quality) (Lüscher et al., 2005; Hopkins and Del Prado, 2007). The impact of climate change on grassland depends on the botanical composition of the sward and can be modified by fertilization and other management practices (Harmens et al., 2002). Climate change can have differed effects on grasslands: elevated $\mathrm{CO}_{2}$ concentrations will generally increase grassland productivity while predicted less precipitation, especially during summer periods, might lead to drought periods resulting in smaller yields; more rainfall in winter can lead to waterlogging on sensitive soils (e.g. Thornley and Cannell, 1997; Dukes et al., 2005).

\subsection{The NaLaMa-nt Project}

The investigations in the context of this dissertation were conducted within the scope of the joint research project NaLaMa-nT: Sustainable land management in the North German Plain. The aim of the project was to establish a knowledge and decisions basis 
for an innovative and sustainable land management in the North German Plain (NGP) that considers the changing ecologic, economic and social frame conditions.

The NGP is a part of the geomorphic formation North European Plain (NEP, elevation 0 to $200 \mathrm{~m}$ above sea level) which stretches from the Netherlands to Poland/Lithuania. In the South, it is confined by the Central European Highlands while bordered by the North Sea in the western part and the Baltic Sea in the East. The climatic conditions in the survey area range from sub-maritime conditions in the west to sub-continental conditions in the east.

The aim of the subproject "Grassland" within NaLaMa-nT was to identify the future challenges and opportunities of grassland farming in northern Germany and to contribute to the development of scenarios for a more sustainable land use, including grassland. In four representative model regions in norther Germany (Fig. 1.1) the status quo of grassland farming systems were analyzed. The model regions differed in land-use, economic and ecological factors and social framework.

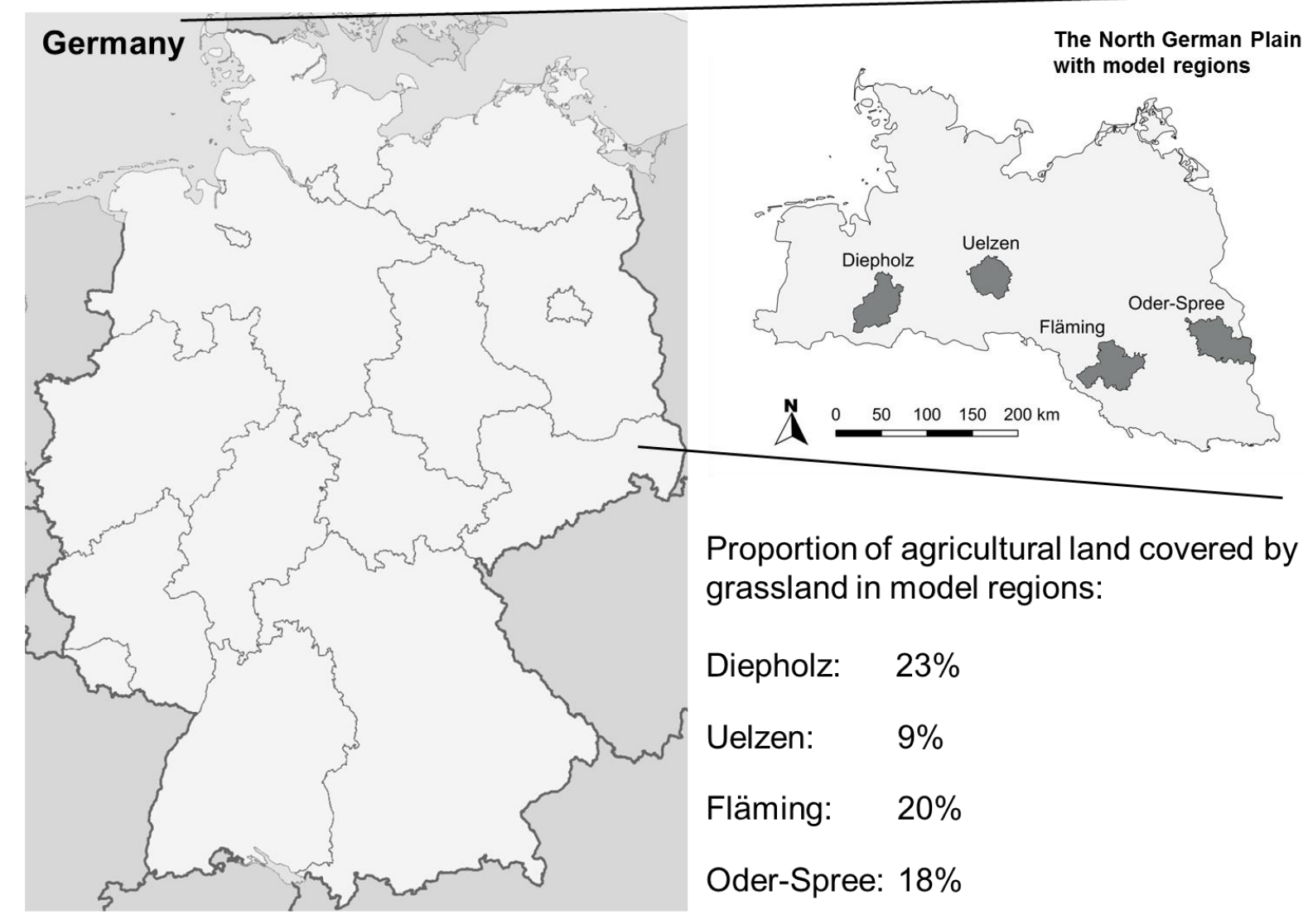

Fig 1.1: North German Plain with the four NaLaMa-nT model regions Diepholz, Uelzen, Fläming and Oder-Spree (right) and the geographical location in Germany. 


\subsection{General study aims}

Three investigation approaches were developed to analyze different aspects of grassland farming in northern Germany where new research results can foster sustainable grassland management.

In this thesis the results of these three approaches; 1) a sociocultural approach, 2) a test method validation approach and 3) a field experiment approach) are presented.

1) In the second chapter the attitude and behavior of grassland farmers concerning voluntary agri-environment measures (AEM) were analyzed. Advisory services can benefit from a better understanding of the ways farmers think and feel and hence adapt their communication with the farming community. We conducted face to face interviews on 82 farms in four model regions in northern Germany and asked questions on personal, business and management data as well as questions on personality traits, general land use preferences, economic factors and social frame conditions.

(On-farm survey and interview - CHAPTER 2).

2) In the third chapter the reliability of the ${ }^{13} \mathrm{C}$ isotopic signatures in cattle tail switch hair as an indicator to validate cattle production systems that are supposed to be based on forage from pasture and not maize was tested. We sampled hair and obtained information on management and annual mean composition of diets on 23 cattle farms in northern Germany of different grazing regimes (year-round grazing, summer grazing, no grazing).

(Isotopic analysis - CHAPTER 3).

3) Chapter four is concerned with the intensification of forage production on typical sandy soils in northern Germany. It was analyzed how intensification can lead to adequate yield and forage qualities while simultaneously preserving other ecosystem services of forage production systems. In a three year experiment four management intensity levels representing four typical forage production systems (moderate permanent grassland, intensive permanent grassland, ley grass, maize) on five sites on a climatic gradient (temperature and precipitation) in northern Germany were analyzed .

(Field experiment - CHAPTER 4). 


\subsection{References}

Bundesamt für Naturschutz (2014) BfN Grünland-Report: Alles im Grünen Bereich? Positionspapier. 34 S., Bonn-Bad Godesberg.

Dabbert, S., Krimly, T. (2004) European grassland farms caught between unfriendly markets, perpetually changing agricultural conditions and environmental demands? Grassland Science in Europe 9, 38-48.

Dukes, J.S., Chiariello, N.R., Cleland, E.E., Moore, L.A., Shaw, M.R., Thayer, S., Tobeck, T., Mooney, H.A., Field, C.B. (2005) Responses of Grassland Production to Single and Multiple Global Environmental Changes. PLoS Biology 3, e319.

Gibon, A. (2005) Managing grassland for production, the environment and the landscape. Challenges at the farm and the landscape level. Livestock Production Science 96, 11-31.

Gonthier, D.J., Ennis, K.K., Farinas, S., Hsieh, H.-Y., Iverson, A.L., Batáry, P., Rudolphi, J., Tscharntke, T., Cardinale, B.J., and Perfecto, I. (2014) Biodiversity conservation in agriculture requires a multi-scale approach. Proceedings of the Royal Society B: Biological Sciences 281, 1791.

Harmens, H., Williams, P.D., Peters, S.L., Bambrick, M.T., Hopkins, A., Ashenden, T.W. (2002) Impacts of elevated atmospheric $\mathrm{CO}_{2}$ and temperature on plant community structure of a temperate grassland are modulated by cutting frequency. Grass and Forage Science 59, 144-156.

Hopkins, A. and Morris, C. (2002) Multi-functional roles of grassland in organic farming systems. In: Powell, Jane und et al., (Hrsg.) Proceedings of the UK Organic Research 2002 Conference, Organic Centre Wales, Institute of Rural Studies, University of Wales, Aberystwyth, pp. 75-80.

Hopkins, A. and Del Prado, A. (2007) Implications of climate change for grassland in Europe: impacts, adaptions and mitigation options: a review. Grass and Forage Science 62, 118-126.

Isselstein, J., Jeangros, B. and Pavlu, V. (2005) Agronomic aspects of biodiversity targeted management of temperate grasslands in Europe - A review. Agronomy Research 3, 139-151.

Isselstein, J. and Kayser, M. (2012) Standortangepasste Strategien zur Lösung von Landnutzungs-konflikten. In: (Ed. Vorstand des Dachverbandes Agrarforschung), Nutzungskonkurrenzen in der Landschaft - Ursachen, Auswirkungen und Lösungsansätze, pp. 153 - 169. Agrarspectrum, Schriftenreihe Band 45, DLG-Verlag, Frankfurt.

Isselstein, J. and Kayser, M. (2014) Functions of grassland and their potential in delivering ecosystem services. Grassland Science in Europe 19, 199-214.

Jeangros, B. and Thomet, P. (2004) Multi-functionality of grassland systems in Switzerland. Grassland Science in Europe 9, 11-23. 
Lehmann, B. and Hediger, W. (2004) The contribution of grassland to social benefits of agriculture - an economic analysis. Grassland Science in Europe 9, 105-116.

Luscher, A., Fuhrer, J. and Newton, P.C.D. (2005) Global atmospheric change and its effect on managed grassland systems. In: McGilloway D.A. (Hrsg.) Grassland: a global resource. Wageningen Academic Publishers, 251-264.

Matzdorf, B. and Lorenz, J. (2010) How cost-effective are result-oriented agrienvironmental measures?-An empirical analysis in Germany. Land Use Policy 27, $535-544$.

Offermann, F., Gomann, H., Kreins, P., Von Ledebur, O., Pelikan, J., Salamon, P. and Sanders, J. (2010) vTI-Baseline 2009 to 2019: Agri-economic projections for Germany. Landbauforschung - vTI Agriculture and Forestry Research 60, 157-172.

Pe'er, G., Dicks, L.V., Visconti, P., Arlettaz, R., Baldi, A., Benton, T.G., Collins, S., Dieterich, M., Gregory, R.D., Hartig, F., Henle, K., Hobson, P.R., Kleijn, D., Neumann, R.K., Robijns, T., Schmidt, J., Shwartz, A., Sutherland, W.J., Turbe, A., Wulf, F., Scott, A.V. (2014) EU agricultural reform fails on biodiversity. Science 344, 1090-1092.

Peeters, A. (2009) Importance, evolution, environmental impact and future challenges for grasslands and grassland-based systems in Europe. Grassland Science 55, 113-125.

Reheul, D., Cougnon, M., De Cauwer, B., Swanckaert, J., Pannecoucque, J., D’Hose, T., Van Den Nest, T., De Caesteker, E., Vaes, R., Peeters, A., Baert, J. and de Vliegher, A. (2015) Production potential of grassland and fodder crops in high-output systems in the Low Countries in north western Europe and how to deal with limiting factors. Grassland Science in Europe 20, 139-150.

Rotz, C., Taube, F., Russelle, M., Oenema, J., Sanderson, M., and Wachendorf, M. (2005) Whole-Farm Perspectives of Nutrient Flows in Grassland Agriculture. Crop Science 45, 2139-2159.

Sanderson, M. A., Goslee, S. C., Soder, K. J., Skinner, R. H., Tracy, B. F., and Deak, A. (2007) Plant species diversity, ecosystem function, and pasture management - A perspective, Canadian Journal of Plant Science 87, 479-487.

Schroeder, J.J.; Aarts, H.F.M.; Berge, H.F.M. Ten; Keulen, H. Van; Neetson, J.J. (2003) An evaluation of whole farm nitrogen balances and related indices for efficient nitrogen use. European Journal of Agronomy 20, 33 - 44.

Smit, H.J., Metzger M.J., Evert, F. (2008) Spatial distribution of grassland productivity and land use in Europe. Agricultural Systems 98, 208-219.

Soussana, J-F., Lüscher, A. (2007) Temperate grasslands and global atmospheric change: a review. Grass and Forage Science 62, 127-134.

Taube, F. and Conijn, J. (2007) Grassland renovation in Northwest Europe: current practices and main agro- nomic and environmental questions. In: Grassland resowing 
and grass-arable crop rotations. Third and fourth workshop of the EGF working group. Report 148. Wageningen Plant Research International. 35- 38.

Taube, F. and Wachendorf, M. (2004) Indikator gestützte Bewertung der Weide im Hinblick auf Leistung und ökologische Effekte. Mitteillungen der Arbeitsgemeinschaft Grünland und Futterbau 6, 167-170.

Thornley, J.H.M. and Cannell, M.G.R. (1997) Temperate Grassland Responses to Climate Change: an Analysis using the Hurley Pasture Model. Annals of Botany 80, 205-221.

Treyse, K., Kelm, M., Mehrtens, H., Taube, F. (2008) An indicator-based approach for assessing sustainability of intensively managed grassland. Berichte über Landwirtschaft 86, 79-102.

Van Passel, S., Nevens, F., Mathijs, E. and van Huylenbroeck, G. (2006) Measuring farm sustainability and explaining differences in sustainable efficiency. Ecological Economics 62, 149-161. 


\section{CHAPTER 2}

The attitude of grassland farmers towards nature conservation and agri-environment measures

- A survey-based analysis

V. Hammes, M. Eggers, J. Isselstein and M. Kayser

Published in Land Use Policy 2016 


\subsection{Abstract}

Grasslands have a multi-layer protection function for nature, biodiversity and climate. These functions can be fostered by an adapted management on grassland farms. Promoting nature protection alongside agricultural production is an aim of European agricultural policy. However, a number of studies indicate that existing Agri-environment measures (AEM) are not as effective as assumed, mainly because they are not sufficiently used by farmers. We investigated the view of grassland farmers on nature conservation and on existing AEM in four distinct regions on a west to east gradient in the North German Plain. We conducted a survey on 82 grassland farms inquiring basic farm data and asking questions on general agricultural issues and nature protection. The results indicate that the majority of all respondents is generally interested in nature conservation and believes it to be of concern for every farmer. In contrast, only a minority of grassland farmers is using the existing AEM to the full extend on their own farm. By applying the concept of farming styles, we classified farmers into four groups, namely Traditionalist, Idealist, Modernist, and Yield Optimizer. These farming styles groups differ in farm and management parameters, general attitudes towards agricultural issues, farming objectives and economic success. We found that in our survey the farming styles groups differ in their attitude towards nature conservation. However, they do not differ in the adoption of AEM and have different reasons for not taking part. We state that for a better implementation of AEM into agricultural practice a better communication, which is adapted to the different ways that farmers manage their farm and think and feel, is needed. Consequently, AEM need to be revised as well.

\subsection{Introduction}

Grasslands and especially extensively used grasslands deliver valuable ecosystem services like carbon sequestration, water protection and biodiversity. Consequently, the preservation of grassland becomes more and more important in the landscape context (Matzdorf and Lorenz, 2010; Flessa et al., 2012; Gonthier et al., 2014). Despite this, the proportion of permanent grassland in Germany, and especially of species-rich extensive grassland, has been constantly declining in the last decades (BfN-Grünlandreport, 2014). In order to preserve extensive grassland within predominantly intensive agricultural systems the farmer needs to be actively involved (e.g. de Snoo et al., 2013) and be interested in nature conservation in general. The crucial role that the farmer plays in this 
context has been formally acknowledged in the EU Common Agricultural Policy (CAP) (Burton et al., 2008) and has been investigated in a number of research studies (e.g. Potter and Gasson, 1988; Ahnström et al., 2009).

Agri-environmental measures (AEM) have been introduced as a key tool of the European agricultural policy to foster nature and landscape protection (Benton et al., 2011). Farmers who voluntarily participate in such regionally adapted conservation measures receive governmental support payments. Based on the European Council Regulation 1698/2005, AEM are a mandatory part of the Rural Development Plans (RDP) in EU Member States and are a central element of the second pillar of the Common Agricultural Policy (CAP). Research results show that AEM are not always as efficient as intended and assumed (e.g. Gasson and Hill, 1990; Ilbery and Stiell, 1991; Whitby et al., 1996; Winter, 2000; Boatman et al., 2010). This lack of success of AEM has, among others, also been explained by a poor understanding of how farmers perceive AEM and their individual reasons for participation or non-participation (e.g. Schroeder et al., 2013; de Snoo et al., 2013). A better knowledge about the general attitudes of farmers towards nature conservation and their judgement of existing AEM can be seen as a key for the development of improved AEM. This approach is based on the idea that different farmers have different attitudes and think differently and need to be addressed accordingly.

The aim of this study was to find out how specific farm parameters of farms that manage grasslands in four regions with mixed agricultural use in northern Germany are related to attitudes and actions of the farm managers concerning AEM. Furthermore, we wanted to investigate the underlying reasons of farmers for participation or non-participation in AEM. Grassland management varies fundamentally among regions, different production systems and even within farms. We conducted face to face interviews on 82 farms in four model regions in the North German Plain and asked questions on personal, business and management data as well as questions on personality traits, general land use preferences, economic factors and social frame conditions. We chose farms that managed grassland in typical ways based on regional census data (Dahl and Sauer, 2012) to get a representative picture grassland management in each model region.

We investigated the general attitude of farmers towards nature conservation and AEM and how farm parameters (e.g. farm size, management intensity, age and education of farm manager) are related to these attitudes. Furthermore, we allocated farmers to different farming styles (Van der Ploeg, 1994). The farming style concept combines farm parameters, personality traits and socio-economic background information. 
Schmitzberger et al. (2005) refined this original concept by grouping farmers with similar farming strategies into categories (farming styles) such as 'Traditionalist', 'Yield Optimizer', 'Modernist/Innovative' and 'Idealist'. The concept attracted international attention and has been applied, for example, to pig farmers in the Netherlands and mountain farmers in Austria, among others (Commandeur, 2006; Vanclay et al., 2006). Eggers et al. (2014) analyzed the view of farmers on climate change and found the farming style concept particularly helpful.

We hypothesize, that

1) grassland farmers in northern Germany differ in their attitude towards nature conservation,

2) a positive attitude towards nature conservation in grassland farmers results in a positive attitude towards AEM and to a better participation in AEM,

3) grouping farmers into certain farming styles will further explain their attitudes towards nature conservation in general and participation in AEM in particular.

\subsection{Material and methods}

In this study, 82 farms were chosen to participate in a survey in four model regions (from west to east: Diepholz $n=20$, Uelzen $n=20$, Fläming $n=21$, Oder-Spree $n=21$; Fig. 2.1). The regions are located on a climatic gradient from sub-maritime to sub-continental in the North German Plain (NGP), one of Germany's major geographical regions. The NGP is a part of the geomorphic formation called North European Plain (NEP, elevation 0 to $200 \mathrm{~m}$ above sea level) which stretches from the Netherlands to Poland/Lithuania. In the South, it is confined by the Central European Highlands while bordered by the North Sea in the western part and the Baltic Sea in the East (Fig. 2.1). The four model regions differ in land-use preferences, economic factors and social framework (Tab.2.1). Grassland is not the predominant agricultural use but ranges from $9 \%$ to $22 \%$ of agricultural land. 
Tab. 2.1: Some basic information about the model regions.

\begin{tabular}{lrrrr}
\hline & Diepholz & Uelzen & Fläming & Oder-Spree \\
\hline Area $\left(\mathrm{km}^{2}\right)$ & 1988 & 1454 & 2163 & 2243 \\
Population density (people per km²) & 108 & 65 & 60 & 82 \\
Agricultural land (\% of total area) & 75 & 53 & 49 & 38 \\
Grassland (\% of agricultural land) & 22 & 9 & 20 & 16 \\
Predicted population decrease until 2020 (\%) & - & - & 20 & 11 \\
\hline
\end{tabular}

All interviewed farmers managed at least five hectares of permanent grassland. Traditionally, grassland management is usually not the only land use on many farms in the model regions and is often combined with arable farming. Extensive grassland on marginal land or on wet sites can be found in different production systems - as a basis of production for suckler cows or as set-aside land in intensive dairy or other livestock production. Therefore, the focus is not only on production systems like grassland-based dairy or suckler cows but on the whole range of farms that manage grassland in the regions. To achieve a representative picture of the main production systems in each region, the selection of farms was based on agricultural census data (Dahl and Sauer, 2012) from the Federal Statistical Office of Germany. Within these main groups of production systems 20 farms per region were selected randomly.

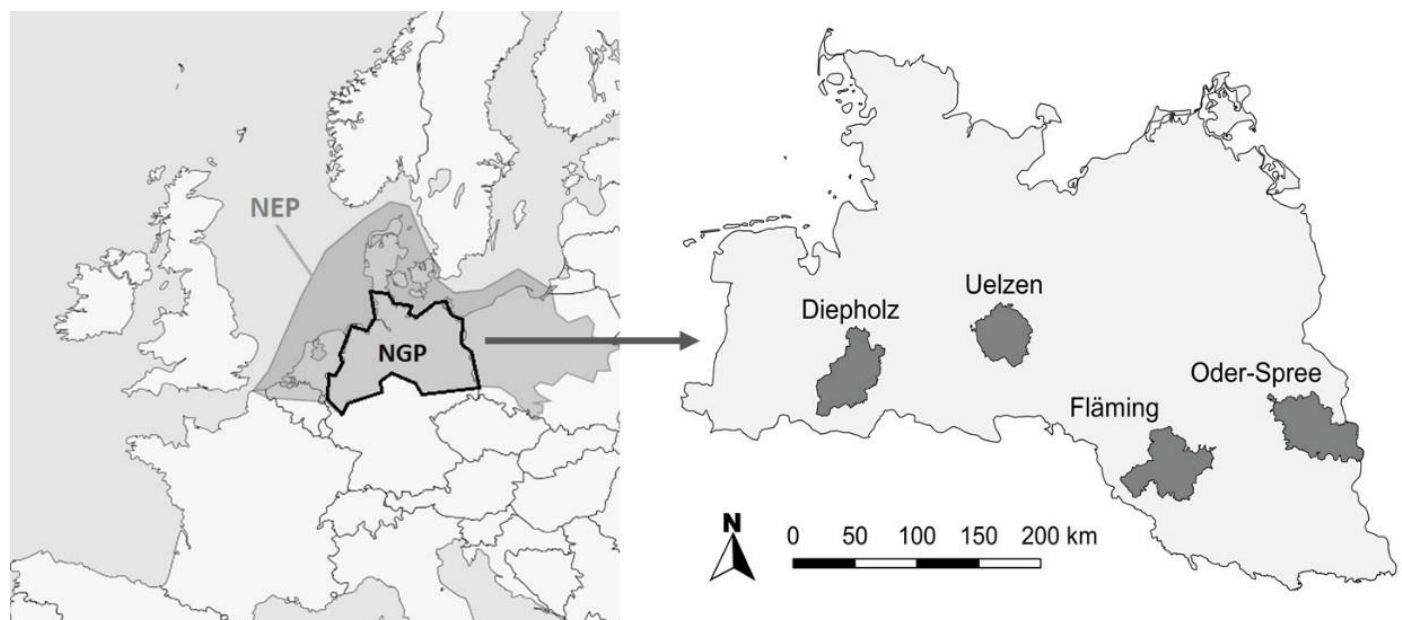

Fig. 2.1: The North German Plain (NGP) within North European Plain (NEP) (left); and NGP with the four regions of this study (from west to east: Diepholz, Uelzen, Fläming, Oder-Spree) (right).

A standardized questionnaire was developed to be answered in face-to-face interviews by the participating farmers. The interviewer transcribed the data and information given by the farmers. 
The questionnaire consisted of two parts: in the first section, we asked 62 questions concerning personal data, farm management and business management; the second section contained 58 statements on general agricultural issues and nature protection issues. The respondents stated their degree of agreement on a five-point Likert scale (1=totally agree, 5=totally disagree). After finishing the regular interview by questionnaire, we allowed for enough time to talk to the farmer about problems and possibilities concerning agriculture, nature conservation and AEM.

In analyzing the data, we proceeded as follows: in the first step (1), we looked at data on farm size, farming intensity, education and age of the farmer and whether this data are related to the farmers' attitude towards conservation and AEM and to the actual number of AEM participants. In a second step (2), we allocated farmers to four distinctive farming styles, which allowed us to (3) elucidate the background of the different attitudes of farmers towards nature conservation and AEM.

\subsubsection{The concept of attitudes}

Attitudes are considered as a central concept of social psychology (Ajzen, 2005). However, the concept of attitude is complex, difficult for psychologists and researches to define and, consequently, has changed considerably over the years (Allport, 1954; Dillard, 1993). In earlier definitions attitudes were described as persistent states of mind with a close relationship to the behavior of an individual. For example, Allport (1935) defined an attitude as "a mental and neural state of readiness, organized through experience, exerting a directive and dynamic influence upon the individual's response to all objects and situations with which it is related". Later the concept of attitudes was mainly reduced to its evaluative component. Bem (1970) defined attitudes only as "likes and dislikes" and Fishbein and Azjen (1975) defined attitude as "a learned predisposition to respond in a consistently favorable or unfavorable manner with respect to a given object" while Petty and Cacioppo (1981) saw it as "a general and enduring positive or negative feeling about some person, object, or issue". There is a vast amount of literature on how to measure attitudes (Thurstone,1928; Likert, 1932; Sherman, 1932).

In this study we follow Eagly and Chaiken (1993) who defined attitude as "a psychological tendency that is expressed by evaluating a particular entity with some degree of favor or disfavor". We measured the degree of favor or disfavor of farmers to certain statements to AEM and nature conservation (five-point Likert scale), and 
combined this with information on farm parameters and personality traits to deduce attitudes of farmers towards nature conservation and AEM.

\subsubsection{Statistics and farming styles}

A cluster analysis was carried out to identify possible grouping variables from the information obtained from the first part of the questionnaire (farm size, nitrogen input, stocking rate, cutting frequency of grassland, education and age of farm manager). As most of the data was on the ordinal scale (Five-point Likert scale), we applied either Mann-Whitney-U tests or Kruskal-Wallis one-way analysis of variance by ranks (Bühner, 2006) to identify significant differences between groups. To suggest a quasi-interval scale of the survey data with equal scale sections, all rating scales were clearly demarcated at the endpoints and had numbered squares (Bühner, 2006; Weiber and Mühlhaus, 2010). All statistical analyses were conducted using the software R! version 3.1.2.

We chose four major farming styles (see Eggers et al., 2014) which are representative for the model regions, namely Traditionalist, Idealist, Modernist and Yield Optimizer. The selection process considered information from the literature (Van der Ploeg, 1994; Vanclay et al., 2006; Defra, 2008; McRae-Williams, 2009; Barnes and Toma, 2012) and the opinions of experts and stakeholders in the model regions.

For the allocation of farmers to certain farming style groups we followed the approach of Schmitzberger et al. (2005): we used 47 Likert-scaled (Scott and Marshall, 2009) statements in our survey to derive classification criteria. Statements were assessed as being positive, negative or neutral for a specific farming style (ranging from -1 to 1 ). They were used to distinguish the four predefined farming styles that we had chosen as relevant for our study. We then allocated each statement to a category and gave scores. For example, a farmer who agreed with the statement 'My main goal is a return on invested capital' was allocated a score for the Yield Optimizer category. A farmer who disagreed with the statement received a score for the Idealist farming style. Finally, we aggregated the scores and arrived at four scores for each farmer for each farming style. For example: Farmer 1: Traditionalist: -17, Idealist: 1, Modernist: 15, Yield-Optimizer: 24. We then allocated the farmer to the farming style with the highest positive score (in the example: Yield-Optimizer). Besides allocating the farmer to a certain farming style we also obtained an individual behavioral pattern for each farmer (see Eggers et al., 2014). 


\subsection{Results and discussion}

As participation in AEM is voluntary, it is important to motivate farmers to use these measures and to join the programs. It is therefore crucial to know what farmers think about nature conservation in general and why they do or do not participate in AEM (e.g. Morris and Potter, 1995; Wilson, 1996; Wilson and Hart, 2000, 2001; Boonstra et al., 2011; de Snoo et al., 2013). These studies usually dealt with farmers from different countries or different business forms (e.g. organic vs conventional), and tried to elucidate differences in their attitudes. In our survey, we focused on farms that manage grassland in four model regions in northern Germany. We found distinct differences among farmers in their attitude towards nature conservation and AEM.

When analyzing the attitude of farmers towards nature conservation and AEM, we suggest that it is advisable to distinguish between

- farmers' attitude towards nature conservation

- farmers' attitude towards AEM, and

- farmers' actual participation in AEM.

Our findings stress the importance of understanding the underlying reasons for the attitudes and decisions of farmers. In the following, we present and discuss results from our survey about the general attitude of farmers towards nature conservation and AEM and how they were related to farm parameters. Finally we used the farming style concept to further explain farmers' attitude and actions concerning nature conservation and AEM by combining farm parameters, personality traits and socio-economic background information.

\subsubsection{General attitude of farmers}

Nearly $60 \%$ of all interviewed farmers stated that a farmer should play an active part in nature conservation. Only $12 \%$ of all farmers disagreed with this statement (Fig. 2.2, s27). However, only $38 \%$ of the farmers in the survey stated that they use AEM "as far as possible" (Fig. 2.3, s15) and $45 \%$ were actually implementing AEM. About $40 \%$ of all interviewed farmers believed AEM to be an important tool to preserve landscape and nature, while another $40 \%$ did not agree with this (Fig. 2.3, s18). As a reason for not participating, $30 \%$ of the farmers referred to too small compensation payments. On the other hand, another $30 \%$ stated that these payments were not too low (Fig. 2.3, s19). 
Trade-offs between economic pressure in agricultural production and conservation activities have been identified as reasons which prevent farmers from taking part in AEM (Gasson and Potter, 1988; Mccann et al., 1997). In our study, however, for $70 \%$ of the interviewed grassland farmers' low financial incentives were not the main reason for their non-participation in AEM (Fig. 2.2, s30) (compare Wilson and Hart, 2001; Burton et al., 2008).

We chose statements s27 and s15 (see Fig. 2.2 and 2.3) as key statements and used them to further explore the somewhat differing attitudes of farmers towards nature conservation and AEM. We found only a weak correlation between farmers' attitude towards nature conservation and AEM (correlation of statements s15 and s27: $\mathrm{R}^{2}=0.37$ ). Furthermore, farmers who were actually taking part in AEM did not show a more positive attitude towards nature conservation compared to farmers that did not participate in AEM (Tab. 2.4). Some studies conclude that the attitude of farmers towards nature conservation can explain their participation or non-participation in AEM (Potter and Gasson, 1988; Brotherton, 1989 and 1991; Moss, 1994; Saunders, 1994). Coleman et al. (1992) state that policy measures that lead to a more positive attitude of farmers towards nature conservation will be more effective than those which provide only 'temporary bribes'. Burton et al. (2008) add that participation in voluntary conservation measures only return little symbolic capital to the reputation of farmers and that this would be different if the image of nature conservation amongst the farming community could be polished and improved. Based on our findings, we state that a positive attitude towards nature conservation does not automatically lead to a positive attitude towards AEM and participation in AEM. Other parameters are involved in the decision-making process.

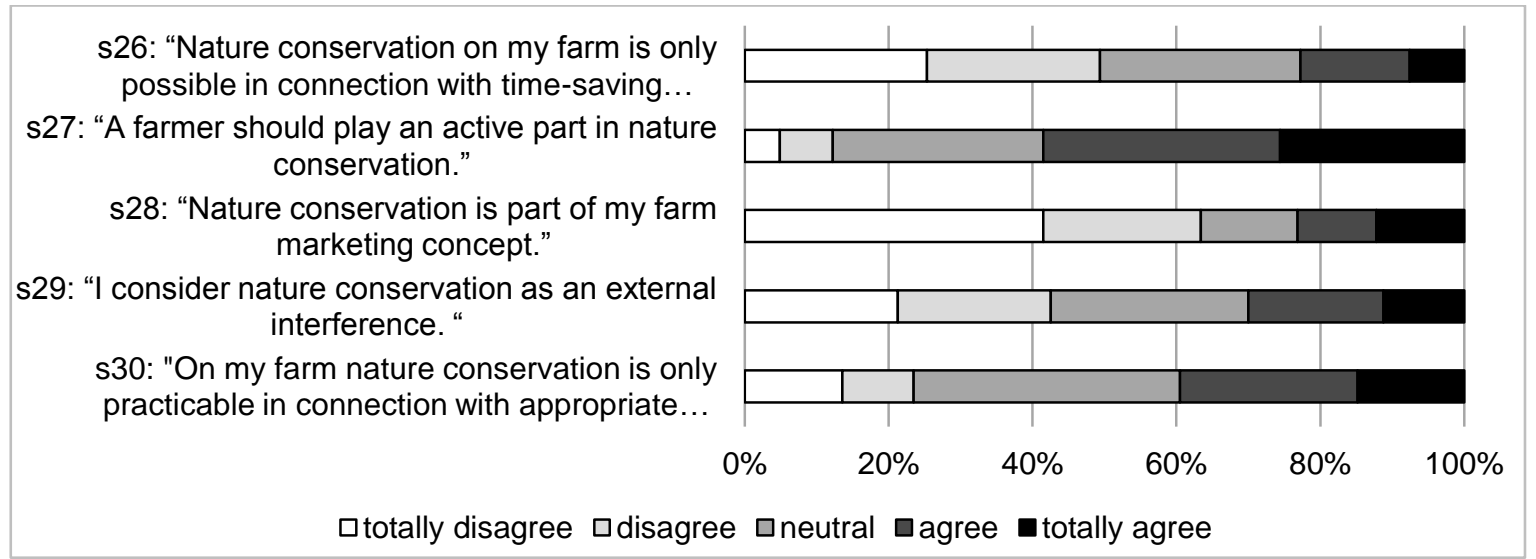

Fig. 2.2: Agreement of interviewed farmers to statements s26-s30 on nature conservation. Five-point Likert scale: 1 = totally disagree, $5=$ totally agree. 


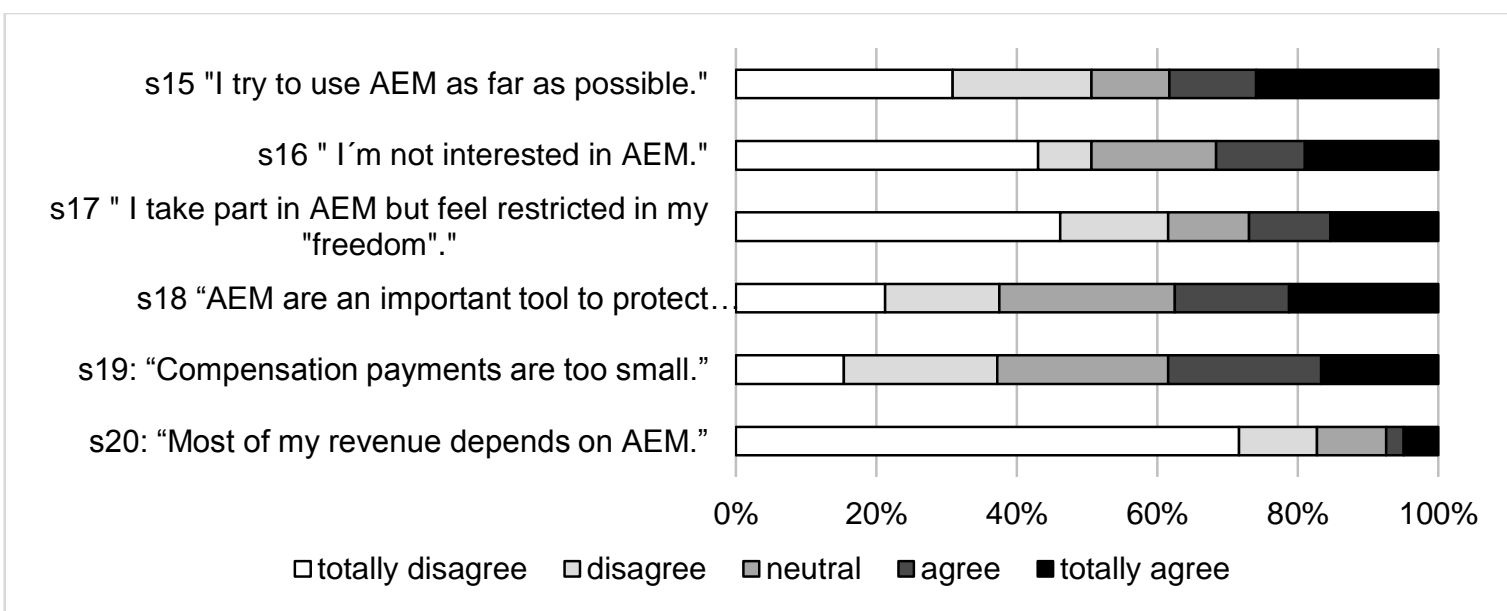

Fig. 2.3: Agreement of interviewed farmers to statements s15-s20 on agri-environment measures (AEM). Five-point Likert scale: $1=$ totally disagree, $5=$ totally agree.

\subsubsection{Farms in model regions}

The four model regions do not only differ in the size and proportion of agricultural land and grassland to the total area (Tab. 2.1) but also in the way grassland farms are organized and managed (Tab. 2.2). Typical grassland farms were smallest in Diepholz and these had the highest $\mathrm{N}$ input rate to grassland to support high stocking rates. We found a trend of decreasing management intensity of grassland farms from the western regions (Diepholz, Uelzen) to the eastern regions (Fläming, Oder-Spree) (Tab. 2.2). On the other hand, age and education of farmers in the survey were at a similar level in all regions.

Intensive or moderate dairy farming with corresponding intensity of grassland management dominated in Diepholz. In Oder-Spree a more extensive grassland management for suckler cows was prevalent. About a third of the grassland farms in Uelzen and Fläming were producing field crops as well (Tab. 2.2). 
Tab. 2.2: Farm size, management and predominant grassland use of the 82 farms in the survey for the four model regions (regional means). LU/ha $=$ Livestock units per hectare, $\mathrm{N}=$ Nitrogen (from organic and artificial fertilizer).

\begin{tabular}{|c|c|c|c|c|}
\hline Parameter & Diepholz & Uelzen & Fläming & $\begin{array}{l}\text { Oder- } \\
\text { Spree }\end{array}$ \\
\hline \multicolumn{5}{|l|}{ Farm size and management: } \\
\hline $\mathrm{N}$ input on grassland $(\mathrm{kg} \mathrm{N} / \mathrm{ha} / \mathrm{yr})$ & $230.4^{\mathrm{a}}$ & $184.5^{\mathrm{ab}}$ & $95.4^{\mathrm{bc}}$ & $54.4^{\mathrm{c}}$ \\
\hline Stocking Rate (LU/ha agricultural land) & $1.6^{\mathrm{a}}$ & $1.1^{\mathrm{a}}$ & $0.4^{\mathrm{b}}$ & $0.6_{\mathrm{b}}$ \\
\hline Grassland cuts per year $(n)$ & $4,1^{\mathrm{a}}$ & $3,3^{\mathrm{b}}$ & $2,8^{\mathrm{bc}}$ & $2,3^{\mathrm{c}}$ \\
\hline Farm Size (ha agricultural land) & $100.2^{\mathrm{a}}$ & $134.3^{\mathrm{a}}$ & $1305.8^{\mathrm{b}}$ & $752.4^{\mathrm{b}}$ \\
\hline $\begin{array}{l}\text { Grassland (ha) } \\
\text { Grassland of agricultural land }(\%) \\
\text { (calculated on the basis of all data, not from } \\
\text { means) }\end{array}$ & $\begin{array}{l}28.0^{\mathrm{a}} \\
36.2^{\mathrm{a}}\end{array}$ & $\begin{array}{l}28.8^{\mathrm{a}} \\
36.7^{\mathrm{a}}\end{array}$ & $\begin{array}{l}201.6^{\mathrm{b}} \\
31.2^{\mathrm{a}}\end{array}$ & $\begin{array}{l}161.4^{\mathrm{b}} \\
45.8^{\mathrm{a}}\end{array}$ \\
\hline Age of farm manager & $47.4^{\mathrm{a}}$ & $48.8^{\mathrm{a}}$ & $52.6^{\mathrm{a}}$ & $54.6^{\mathrm{a}}$ \\
\hline $\begin{array}{l}\text { Education of farm manager } \\
(1=\text { none, } 6=\text { university study, see Tab. } 2.3)\end{array}$ & $3.9^{\mathrm{a}}$ & $4.6^{\mathrm{a}}$ & $4.4^{\mathrm{a}}$ & $3.8^{\mathrm{a}}$ \\
\hline \multicolumn{5}{|l|}{ Production system: } \\
\hline $\begin{array}{l}\text { Intensive and moderate grassland farms } \\
\text { - Dairy production systems (\%) }\end{array}$ & 75 & 33 & 29 & 33 \\
\hline $\begin{array}{l}\text { Extensive grassland farms } \\
\text { - Suckler cow, horses, sheep keeping (\%) }\end{array}$ & 10 & 14 & 14 & 43 \\
\hline $\begin{array}{l}\text { Grassland on farms with other production } \\
\text { focus } \\
\text { - Grassland (different purposes) (\%) }\end{array}$ & 15 & 38 & 43 & 5 \\
\hline
\end{tabular}

Letters $\mathrm{a}, \mathrm{b}$ and $\mathrm{c}$ indicate significant differences $(\mathrm{p}<0.05)$ among model regions (columns) tested with Kruskal-Wallis one-way analysis of variance on ranks.

Farmers in Diepholz agreed significantly less to the key statement s15 on AEM ("I try to use AEM as far as possible”, Tab. 2.3) than farmers in Fläming and Oder-Spree. The percentage of all farmers that were actually using AEM on their farm also differed among model regions: from $25 \%$ in Diepholz to $43 \%$ in Fläming, $52 \%$ in Oder-Spree, and 70 $\%$ in Uelzen; the difference between Diepholz and Uelzen is significant $(\mathrm{p}<0.05)$.

The organization of AEM in Germany is conducted at the federal state level which results in a range of dissimilar requirements and compensation payments (Thomas et al., 2009). However, this fact is not sufficient in explaining the differences in participation in our survey; both, Diepholz and Uelzen are actually located in the same federal state. 


\subsubsection{Farm paramters and attitudes of farmers}

Pražan (2010), in the Czech Republic, found that farms with a higher intensity were less likely to participate in AEM. Similarly in our survey, farmers with a more extensive grassland management (low nitrogen input, lower stocking rates, and low cutting frequency) showed a more positive attitude towards AEM (Tab. 2.3). However, this was not the case with the attitude towards nature conservation: grassland farmers with intensive production systems showed no less interest in nature conservation than their colleagues with more extensive management (data not shown).

Tab. 2.3: Degree of agreement to statement s15: "I try to use AEM as far as possible" of farmers differing in some personal or farm parameters. Agreement on a Five-point Likert scale $(1=$ totally disagree, $5=$ totally agree $)$.

\begin{tabular}{|c|c|c|c|c|c|c|c|c|}
\hline $\begin{array}{l}\mathrm{N} \text { input } \\
\text { on grassland }(p<0.001)\end{array}$ & \multirow{2}{*}{$\begin{array}{l}\text { mean } \\
3.70^{\mathrm{a}}\end{array}$} & \multirow{2}{*}{$\begin{array}{l}\mathrm{sd} \\
1.60\end{array}$} & \multirow{2}{*}{$\begin{array}{l}\mathrm{n} \\
33\end{array}$} & \multirow{2}{*}{$\begin{array}{l}\text { Farm Size } \\
\text { Small }\end{array}$} & \multirow{2}{*}{$\begin{array}{l}(\mathrm{p}=0.112) \\
(5-50 \mathrm{ha})\end{array}$} & \multirow{2}{*}{$\begin{array}{l}\text { mean } \\
2.07\end{array}$} & \multirow{2}{*}{$\begin{array}{l}\mathrm{sd} \\
1.54\end{array}$} & \multirow{2}{*}{$\begin{array}{l}\mathrm{n} \\
14\end{array}$} \\
\hline (0-60 kg N/ha/a) & & & & & & & & \\
\hline (61-130 kg N/ha/a) & $2.60^{\mathrm{ab}}$ & 1.30 & 15 & Medium & $51-250$ ha) & 2.86 & 1.63 & 42 \\
\hline$(131-300 \mathrm{kgN} / \mathrm{ha} / \mathrm{a})$ & $2.32^{\mathrm{b}}$ & 1.43 & 22 & Large & (251-1250 ha) & 3.66 & 1.67 & 12 \\
\hline$(>300$ kgN/ha/a) & $1.55^{\mathrm{b}}$ & 1.04 & 11 & Huge & (>1250 ha) & 2.77 & 1.30 & 13 \\
\hline Stocking rate $(\mathrm{p}<0.001)$ & mean & sd & $\mathrm{n}$ & \multicolumn{2}{|c|}{ Grassland area $(\mathrm{p}=0.163)$} & & & \\
\hline (0-0.7 LU/ha) & $3.49^{\mathrm{a}}$ & 1.52 & 43 & small & (5-20 ha) & 2.83 & 1.61 & 24 \\
\hline (0.8-1.5 LU/ha) & $2.28^{\mathrm{b}}$ & 1.46 & 25 & medium & (21-100 ha) & 2.53 & 1.73 & 36 \\
\hline (>1.6 LU/ha) & $1.69^{\mathrm{b}}$ & 1.18 & 13 & Large & $(>100$ ha $)$ & 3.33 & 1.32 & 21 \\
\hline Cutting frequency $(p<0.001)$ & mean & sd & $\mathrm{n}$ & \multicolumn{2}{|c|}{ Age $(p=0.615)$} & mean & $\mathrm{sd}$ & $\mathrm{n}$ \\
\hline ( $0-2$ cuts/a) & $3.73^{\mathrm{a}}$ & 1.44 & 15 & \multicolumn{2}{|l|}{$<42$ years } & 2.69 & 1.58 & 16 \\
\hline (2-3 cuts/a) & $3.05^{\mathrm{a}}$ & 1.58 & 40 & \multicolumn{2}{|l|}{$42-5$ years } & 2.68 & 1.73 & 22 \\
\hline \multirow[t]{2}{*}{ High } & $1.60^{\mathrm{b}}$ & 0.88 & 20 & \multirow{2}{*}{\multicolumn{2}{|c|}{$\begin{array}{l}52-6 \text { years } \\
>61 \text { years }\end{array}$}} & 2.82 & 1.60 & 34 \\
\hline & & & & & & 3.44 & 1.51 & 9 \\
\hline \multirow[t]{2}{*}{ Model Regions $(\mathrm{p}<\mathbf{0 . 0 5})$} & & & & \multicolumn{2}{|c|}{ Education $(p=0.120)$} & mean & $\mathrm{sd}$ & $\mathrm{n}$ \\
\hline & mean & sd & $\mathrm{n}$ & \multicolumn{2}{|l|}{ None } & 2.27 & 1.39 & 11 \\
\hline Diepholz & $2.20^{\mathrm{a}}$ & 1.47 & 20 & \multicolumn{2}{|c|}{ Vocational Training } & 3.30 & 1.70 & 10 \\
\hline Uelzen & $3.00^{\mathrm{ab}}$ & 1.38 & 20 & \multicolumn{2}{|c|}{ Annual Vocational Collage } & 1.50 & 0.70 & 2 \\
\hline Fläming & $3.38^{\mathrm{b}}$ & 1.43 & 21 & \multicolumn{2}{|c|}{ Biennial Vocational Collage } & 3.00 & 1.84 & 11 \\
\hline \multirow[t]{2}{*}{ Oder-Spree } & $3.42^{\mathrm{b}}$ & 1.17 & 19 & \multicolumn{2}{|c|}{ Master Craftsman } & 2.46 & 1.61 & 24 \\
\hline & & & & \multicolumn{2}{|c|}{ University Studies } & 3.30 & 1.52 & 23 \\
\hline
\end{tabular}

Letters a and $\mathrm{b}$ indicate significant differences $(\mathrm{p}<0.05)$ among group means (rows) tested with Kruskal-Wallis one-way analysis of variance on ranks.

Many studies have revealed demographics to have an influence on the decisions of farmers. It has been reported that young and better educated farmers on comparably smaller farms have a higher concern for nature conservation and are more likely to participate in AEM than others (Bultena and Hoiberg, 1983; Buttel and Gillespie, 1988; Featherstone and Goodwin, 1993). We found that farmers who were actually taking part 
in AEM had larger farm sizes, a higher educational level and lower stocking rates (Tab. 2.4). AEM can be attractive to larger farms as compensation payments are paid per hectare and as these farms often have a certain proportion of marginal land as well.

Tab. 2.4: Differences between farmers that are using AEM and farmers that are not using AEM in degree of agreement to statements s15 and s27 (Degree of agreement on a Fivepoint Likert scale; $1=$ totally disagree, $5=$ totally agree) and in basic personal and farm data.

\begin{tabular}{|c|c|c|c|}
\hline & $\begin{array}{r}\text { Farmers } \\
\text { using AEM } \\
(\mathrm{n}=39)\end{array}$ & $\begin{array}{r}\text { Farmers not } \\
\text { using AEM } \\
(\mathrm{n}=43) \\
\end{array}$ & $\begin{array}{r}\text { Significance } \\
\text { of difference } \\
\text { p value }\end{array}$ \\
\hline $\begin{array}{l}\text { Degree of agreement to statement s15: } \\
\text { "I try to use AEM as far as possible." } \\
\text { (Five-point Likert scale) }\end{array}$ & 3.53 & 2.21 & $\mathrm{p}<0.001$ \\
\hline $\begin{array}{l}\text { Degree of agreement to statement s27: } \\
\text { "A farmer should play an active part in } \\
\text { nature conservation "(Five-point Likert } \\
\text { scale) }\end{array}$ & 3.77 & 3.58 & $\mathrm{p}=0.343$ \\
\hline $\mathrm{N}$ input on grassland $(\mathrm{kg} \mathrm{N} / \mathrm{ha} / \mathrm{a})$ & 119.78 & 157.49 & $\mathrm{p}=0.123$ \\
\hline Stocking rate (LU/ha) & 0.69 & 1.09 & $\mathrm{p}=\mathbf{0 . 0 2 8}$ \\
\hline Cuts per year (n) & 2.40 & 2.82 & $\mathrm{p}=0.221$ \\
\hline Farm Size (ha) & 648.91 & 525.69 & $p=0.044$ \\
\hline Grassland (ha) & 132.12 & 83.84 & $\mathrm{p}=0.477$ \\
\hline Age of farm manager (years) & 50.82 & 50.98 & $\mathrm{p}=0.780$ \\
\hline $\begin{array}{l}\text { Education (levels 1-6, for notations see } \\
\text { Tab. 2.3) }\end{array}$ & 4.64 & 3.74 & $p=0.047$ \\
\hline
\end{tabular}

Significance of differences was tested with Kruskal-Wallis one-way analysis of variance on ranks.

\subsubsection{Applying the farming style concept}

The differences in attitude and behavior of farmers towards nature conservation and AEM are complex and not easily explained by business or demographic parameters alone. In consequence, we enhanced our analysis to include personality traits of the farmers. Seabrook and Higgins (1988) introduced the idea of a "Self-Concept" of each farmer. It is an image that a farmer has of himself or herself and determines the way he/she assigns or confines himself/herself to a particular social group with specific values and goals. Farmers of similar farming systems (Van der Ploeg, 1994; Schmitzberger et al., 2005) can differ substantially in their attitudes and actions due to very different self-images (Schoon and Grotenhuis, 2000; Boonstra et al., 2011). Thus, we assume that the image farmers have of themselves contributes to their decision whether to participate in AEM or not. Family plays a role, too, and their opinion has been found to be more important than that of consultants and farm advisors (Schroeder et al., 2015).

Our data confirm the findings of Schmitzberger et al. (2005) that farmers of different farming styles (Traditionalist, Idealist, Modernist, Yield Optimizer) differ in their attitude 
towards nature conservation. Traditionalists and Yield Optimizers agreed less to the statement s27 "A farmer should play an active part in nature conservation." than Idealists (Tab. 2.5). However, we found that grassland farmers of different farming styles did not differ in their degree of agreement to statement s15 "I try to use AEM as far as possible." (Tab. 2.5).

Tab. 2.5: Degree of agreement of farming styles to statements s27 and s15. Agreement on a Five-point Likert scale $(1=$ totally disagree, $5=$ totally agree $)$ and percentage of farmers that actually use AEM.

\begin{tabular}{lcc}
\hline Farming style & $\begin{array}{c}\text { Degree of agreement (s27): } \\
\text { "A farmer should play an active part in } \\
\text { nature conservation." }\end{array}$ & $\begin{array}{c}\text { Degree of agreement (s15): } \\
\text { "I try to use AEM as far as } \\
\text { possible." }\end{array}$ \\
\hline Traditionalist & $3.09^{\mathrm{a}}$ & $2.60^{\mathrm{a}}$ \\
Idealist & $4.12^{\mathrm{b}}$ & $3.19^{\mathrm{a}}$ \\
Modernist & $4.10^{\mathrm{ab}}$ & $3.00^{\mathrm{a}}$ \\
Yield Optimizer & $3.36^{\mathrm{ac}}$ & $2.54^{\mathrm{a}}$ \\
\hline Letters a,b,c indicate significant differences (p<0.05) among farming styles (rows) tested with \\
Kruskal-Wallis one-way analysis of variance on ranks.
\end{tabular}

There was also no difference in participation in AEM among the four farming styles (data not shown). This strengthens our assumption that the attitude towards nature conservation does not necessarily lead to similar actions concerning participation in AEM.

Farmers of different farming styles, however, showed different attitudes towards some other aspects of AEM (statements s16-s20). The differences in their attitude towards nature conservation (statements s26-s30) will be briefly summarized by combining the answers to the statements of the interview (only significant differences (Kruskal-Wallis one-way analysis of variance on ranks, $\mathrm{p}<0.05$ ) are considered) in the following paragraphs. For statements see Fig. 2.2 and Fig. 2.3.

Traditionalists have a negative attitude towards nature conservation in general (s27). They perceive conservation as an external interference in their farm business (s29). These farmers could not be persuaded by compensation payments to integrate nature conservation into their business (s30). Their way of managing their land and business is influenced a lot by traditions. AEM-consultants should therefore address Traditionalists on an emotional level and not as mere producers.

Idealists show a more positive attitude towards nature conservation (s27) and believe AEM to be an important tool to protect nature and landscape (s18) and do not see nature conservation as an external interference (s29). However, in spite of this positive attitude they do not use AEM more often than other farming styles (data not shown). In our study 
$40 \%$ of the Idealists manage organic farms and thus would benefit from assistance on how to use AEM in combination with subsidies for organic farming.

Modernists have a positive attitude towards nature conservation (s27). They use AEM slightly more often than farmers of other farming styles; however, this difference is not significant. In contrast to Traditionalists, Modernists do not perceive conservation programs as an undesired external interference in their farm business (s29). Hence, they would benefit from information on new possibilities of integrating AEM in a profitable way into their farm business.

Yield Optimizers believe less than Idealists that farmers should play an active part in nature conservation (s27). They think that nature conservation is only practicable with appropriate compensation payments (s30). Apart from that, Yield Optimizers do not see a benefit for nature and landscape by using AEM (s18). However, if AEM could be implemented in a profitable way into their business, e.g. on marginal agricultural land which they had abandoned from cultivation, Yield Optimizers could be convinced to use AEM.

It has been stated that farmers often show a rather negative general attitude towards government authorities and public administration and that their trust in public organizations is low (Cantrill, 2003). This might affect their view on governmental conservation programs (Aggelopoulos et al., 2016; Gronewold et al., 2012). We did not have a statement in our survey that directly relates to farmers' attitude towards governmental organizations. However, statement 29 in our survey ("I consider nature conservation as an external interference") points in the same direction and about $30 \%$ of all interviewed farmers agreed with this statement. Traditionalists especially are critical in this respect, while Idealists and Modernists are less negative.

We conclude that the farming style of each farmer, which combines the personality traits and the frame conditions of the business, summarizes the key factors in their decisionmaking process. We agree with Eggers et al. (2014) that applying the farming styles concept can improve understanding and communication among governmental or environmental stakeholders and the farming community. It can foster the development of a communication that is well adapted to the varying requirements of different groups of farmers. Vanslembrouck et al. (2002) also stressed the need for communication between stakeholders from agriculture, policy and conservation to improve implementation of 
AEM in agricultural practice. Nature conservation on a landscape scale can only be achieved in cooperation with the farming community.

\subsubsection{Open conversations with farmers}

During an open conversation subsequent to the interview with the standardized questionnaire, farmers came up with a number of additional reasons for not participating in AEM. Some reasons seem to be specific to certain farming styles (see Tab. 2.6). Only Traditionalists and Idealists mentioned the complexity of the application forms as an obstacle. This seems to be independent of the educational background as we found Idealists to have spent a longer time in education than Traditionalists (data not shown). Furthermore, Traditionalists and Idealists worry that they might unintentionally give wrong information and would have to pay back compensation payments.

Another important impediment seems to be the long minimum participation time of most AEM (usually 5 years; European Council, 2005). In fact, short term AEM have only little positive effect on nature conservation (Moxey et al., 1999). However, long-term AEM can restrict farm development and thus the adaption to market fluctuations. What might help to increase participation among farmers is if they could participate in AEM in more flexible ways and if the advisory service would be improved as well (Wilson, 1997).

The new CAP reform has introduced compulsory greening schemes and payments targeted at agricultural practices that are beneficial for the climate and the environment. This includes maintaining permanent grassland, crop diversification and maintaining an 'ecological focus area' of at least $5 \%$ of the arable farm land. Consequently, some farmers might be even less interested in taking part in additional voluntary AEM - and land might already be used for the greening scheme. Whereas AEM are regionally adapted, conservation programs and the greening schemes are not, and this might be a step backwards in implementing regional conservation measures. 
Tab. 2.6: Reasons for non-participation in AEM mentioned by farmers during open conversations subsequent to our interview with the standardized questionnaire.

\begin{tabular}{ll}
\hline Reasons for not using AEM by farmers & Farming Style \\
\hline Complexity of AEM application forms & Traditionalist, Idealist \\
Afraid of unintendedly giving wrong information and repayment & Traditionalist, Idealist \\
Long minimum participation time of AEM (usually 5 years) & Traditionalist, Idealist, \\
No need for participation due to high income & Modernist \\
\hline
\end{tabular}

\subsection{Conclusions}

Less than half of the interviewed farmers in northern Germany use AEM. Improving the image of nature conservation amongst the farming community alone would not help much to increase AEM participation numbers. The attitude of farmers towards AEM and their actual participation in these programs is influenced by basic farm parameters in combination with the personality traits of each farmer. Moreover, applying the farming styles concept on grassland farmers improves our understanding of the farmers' decisionmaking process. This approach could thus help to provide the basis for better communication among governmental or environmental stakeholders and the farming community. Clearly, nature conservation on a landscape scale can only be achieved in cooperation with the farming community. We agree with Ahnström (2009) who emphasized the importance of making farmers aware of the crucial role they play in nature conservation and to place "farmland biodiversity in the hands and minds of farmers".

\subsection{Acknowledgments}

This project (Nachhaltiges Landmanagement im Norddeutschen Tiefland, FKZ 033L029) was supported by the German Ministry of Research (BMBF). 


\subsection{References}

Aggelopoulos, S., Karelakis, C., Tsantopoulos, G., Pavloudi, A., and Seitanis, P. (2016) Farmers' perceptions and attitudes towards the development of the sheep and goat sector in the Greek region of Evros. SpringerPlus 5, 1134.

Ahnström, J. (2009) Farmland biodiversity - in the hands and minds of farmers. Effects of landscape structure, management and the farmer's interest in nature. Thesis. Swedish University of Agricultural Sciences, Uppsala.

Ahnström, J., Höckert, J., Bergeå L, H., Francis, C.A., Skelton, P. and Hallgren, L. (2009) Farmers and nature conservation: What is known about attitudes, context factors and actions affecting conservation? Renewable Agriculture and Food Systems 24, 3847.

Ajzen, I. (2005) Attitudes, personality and behavior. NY: Open University Press.

Allport, G.W. (1935) Attitudes. In C. Murchison (Ed.), Handbook of social psychology. Worcester, Mass: Clark University Press.

Allport, G.W. (1954) The historical background of modern social psychology. In G. Lindzey (Ed.), Handbook of social psychology (Vol. 1, pp. 3-56). Cambridge, MA: Addison-Wesley.

Barnes, A. P. and Toma, L. (2012) A typology of dairy farmer perceptions towards climate change. Climate Change 112, 507-522.

Bem, D.J. (1970) Beliefs, attitudes, and human affairs. Belmont, CA: Brook s/Cole. Benton, T., Hartel, T. and Settele, J. (2011) Food security: A role for Europe. Nature 480, 39-39.

Boatman, N., Green, M., Holland, J., Marshall, J., Renwick, A., Siriwardena, G., Smith, B., and Snoo, G. de (2010) Agri-environment Schemes - What have they achieved and where do we go from here? Oadby, UK, 27-29 April 2010. (Association of Applied Biologists). 1-447.

Boonstra, W. J., Ahnström, J. and Hallgren, L. (2011) Swedish Farmers Talking about Nature - A Study of the Interrelations between Farmers' Values and the Sociocultural Notion of Naturintresse. Sociologica Ruralis 51, 420-435.

Brotherton, I. (1989) Farmer participation in voluntary land diversion schemes: Some observations from theory. Journal of Rural Studies 5, 299-304.

Brotherton, I. (1991) What limits participation in ESAs? Journal of Environmental Management 32, 241-249.

Bühner, M. (2006) Einführung in die Test- und Fragebogenkonstruktion. Pearson Studium, München.

Bultena, G. L. and Hoiberg, E.O. (1983) Factors affecting farmers' adoption of conservation tillage. Journal of Soil and Water Conservation 38, 281-284. 
Burton, R. J. F., Kuczera, C. and Schwarz, G. (2008) Exploring Farmers' Cultural Resistance to Voluntary Agri-environmental Schemes. Sociologica Ruralis 48, 16-37.

Buttel, F. H. and Gillespie, G.W. (1988) Preferences for crop production practices among conventional and alternative farmers. American Journal of Alternative Agriculture 3, 11-17.

Cantrill, J.G. (2003) Distrust of government at the end of the road: Finding selves situated in a hinterland place. Communication research reports 20, 277-286.

Commandeur, M.A.M. (2006) Diversity of pig farming styles: understanding how it is structured. NJAS - Wagening. NJAS - Wageningen Journal of Life Sciences 54, 111127.

Coleman, D., Crabtree, B., Froud, J. and O'Carroll, L. (1992) Comparative Effectiveness of Conservation Mechanisms. Department of Agricultural Economics, Manchester University.

Dahl S. and Sauer, S. (2012) Landwirtschaftszählung 2010 Heft 1 Teil AGemeindeergebnisse, Betriebsgrößenstruktur, Bodennutzung, Viehhaltung. Landesbetrieb für Statistik und Kommunikationstechnologie Niedersachsen (eds.). Statistische Berichte Niedersachsen.

Defra (2008) Bringing theoretical and applied evidence together from across Defra and highlighting policy relevance and implications for future research, November 2008. In: Pike T (ed) Defra agricultural change and environment observatory discussion paper.

Dillard, J.P. (1993) Persuasion past and present: Attitudes aren't what they used to be. Communication Monographs 60, 90-97.

Eagly, A. H., \& Chaiken, S. (1993) The psychology of attitudes. Harcourt Brace Jovanovich College Publishers.

Eggers, M., Kayser, M. and Isselstein, J. (2014) Grassland farmers' attitudes toward climate change in the North German Plain. Regional Environmental Change 15, 607617.

Featherstone, A. M. and Goodwin, B.K. (1993) Factors Influencing a Farmer's Decision to Invest in Long-Term Conservation Improvements. Land Economics 69, 67-81.

Fishbein, M., \& Ajzen, I. (1975) Belief, attitude, intention, and behavior: An introduction to theory and research. Reading, MA: Addison-Wesley.

Flessa, H., Müller, D., Plassmann, K., Osterburg, B., Techen, A., Nitsch, H., Nieberg, H., Sanders, J.,Meyer zu Hartlage, O., Beckmann E. and Anspach, V. (2012) Studie zur Vorbereitung einer effizienten und gut abgestimmten Klimaschutzpolitik für den Agrarsektor, vTI Sonderheft 361.

Gasson, R. and Hill, P. (1990) An economic evaluation of the Farm Woodland Scheme. FBU Occasional Paper (17). IX + 175pp. 
Gasson, R. and Potter, C. (1988) Conservation Through Land Diversion: A Survey of Farmers' Attitudes. Journal of Agricultural Economics 39, 340-351.

Gonthier, D.J., Ennis, K.K., Farinas, S., Hsieh, H.-Y., Iverson, A.L., Batáry, P., Rudolphi, J., Tscharntke, T., Cardinale, B.J. and Perfecto, I. (2014) Biodiversity conservation in agriculture requires a multi-scale approach. Proceedings of the Royal Society B: Biological Sciences 281, 20141358.

Gronewold, K.L., Burnett, A., and Meister, M. (2012) Farmers' Cynicism Toward Nature and Distrust of the Government: Where Does that Leave Conservation Buffer Programs? Applied Environmental Education \& Communication 11, 18-24.

Ilbery, B. and Stiell, B. (1991) Uptake of the Farm Diversification Grant Scheme in England. Geography 76, 259-263.

Likert, R. (1932) A technique for the measurement of attitudes. Archives of psychology 140, 1-55.

Matzdorf, B. and Lorenz, J. (2010) How cost-effective are result-oriented agrienvironmental measures?-An empirical analysis in Germany. Land Use Policy 27, $535-544$.

Mccann, E., Sullivan, S., Erickson, D. and Young, R.D. (1997) Environmental Awareness, Economic Orientation, and Farming Practices: A Comparison of Organic and Conventional Farmers. Environmental Management 21, 747-758.

McRae-Williams, P. (2009) WIDCORP 1/09. Understanding farmer knowledge and attitudes to climate change, climate variability, and greenhouse gas emissions. http://www.widcorp.com/publications.php. Accessed 15 Dez. 2014.

Morris, C. and Potter, C. (1995) Recruiting the new conservationists: Farmers' adoption of agri-environmental schemes in the U.K. Journal of Rural Studies 11, 51-63.

Moss, J. (1994) A baseline assessment for a new ESA: the case of the Mourne Mountains and Slieve Croob. In M. C. Whitby (Ed.), Incentives for Countryside Management. Wallingford, UK: CAB International. 153-178.

Moxey, A., White, B., and Ozanne, A. (1999) Efficient Contract Design for AgriEnvironment Policy. Journal of Agricultural Economics 50, 187-202.

Petty, R. E. and Cacioppo, J. T. (1981) Attitudes and persuasion: Classic and contemporary approaches. Dubuque, IA: Wm. C. Brown.

Potter, C. and Gasson, R. (1988) Farmer participation in voluntary land diversion schemes: Some predictions from a survey. Journal of Rural Studies 4, 365-375.

Pražan, J., Majerova, J., and Kapler, P. (2010) Integrating agri-environmental measures in the protected areas of Zdarske Vrchy and Bile Karpaty. Case-study report for Assessing the impact of rural development policies (RuDI) project. 
Saunders, C. (1994) Single-Tier System with Many Farms Partly Outside the ESA. The Case of the Pennine Dales. In M. Whitby (ed.) Incentives for Countryside Management. The Case of Environmentally Sensitive Areas. Wallingford, UK: CAB International. 4159.

Schmitzberger, I., Wrbka, T., Steurer, B., Aschenbrenner, G., Peterseil, J. and Zechmeister, H.G. (2005) How farming styles influence biodiversity maintenance in Austrian agricultural landscapes. Agriculture, Ecosystems and Environment 108, 274 290.

Schoon, B. and Grotenhuis, R. te (2000) Values of Farmers, Sustainability and Agricultural Policy. Journal of Agricultural and Environmental Ethics 12, 17-27.

Schroeder, L.A., Chaplin, S. and Isselstein, J. (2015) What influences farmers' acceptance of agri-environment schemes? An ex-post application of the 'Theory of Planned Behaviour'. Landbauforschung Applied Agricultural and Forestry 65, 15-28.

Schroeder, L.A., Isselstein, J., Chaplin, S. and Peel, S. (2013) Agri-environment schemes: Farmers' acceptance and perception of potential "Payment by Results" in grassland-A case study in England. Land Use Policy 32, 134-144.

Scott, J. and Marshall, G. (2009) A dictionary of sociology. Oxford. University Press, Oxford.

Seabrook, M. F. and Higgins, C. B. R. (1988) The role of the farmer's Self-Concept in determining farmer behaviour. Agricultural Administration and Extension 30, 99-108.

Sherman, M. (1932) Theories and Measurement of Attitudes. Child Development 3, 15.

de Snoo, G.R., Herzon, I., Staats, H., Burton, R.J.F., Schindler, S., van Dijk, J., Lokhorst, A.M., Bullock, J.M., Lobley, M., Wrbka, T., Schwarz, G. and Musters, C. J. M. (2013) Towards effective nature conservation on farmland: making farmers matter. Conservation Letters 6, 66-72.

Thomas, F., Denzel, K., Hartmann, E., Luick, R. and Schmoock, K. (2009) Kurzfassungen der Agrarumwelt- und Naturschutzprogramme. Darstellung und Analyse der Entwicklung von Maßnahmen der Agrarumwelt- und Naturschutzprogramme in der Bundesrepublik Deutschland. Bundesamt für Naturschutz (Hg.) BfN-Skripten 253.

Thurstone, L. L. (1928). Attitudes can be measured. American Journal of Sociology 33, 529-54.

Vanclay, F., Howden, P., Mesiti, L. and Glyde, S. (2006). The Social and Intellectual Construction of Farming styles: Testing Dutch Ideas in Australian Agriculture.

Sociologica Ruralis 46, 61-82.

van der Ploeg, J. D. (1994) Styles of farming: An introductory note on concepts and methodology. In: Van der Ploeg, J.D, Long, A. (eds.). Born from within: Practice and perspectives of endogenous Rural Development. Van Gorcum, Netherlands, 7-30. 
Vanslembrouck, I., Van Huylenbroeck, G., and Verbeke, W. (2002). Determinants of the Willingness of Belgian Farmers to Participate in Agri-environmental Measures. Journal of Agricultural Economics 53, 489-511.

Weiber, R. and Mühlhaus, D. (2010) Strukturgleichungsmodellierung - Eine anwenderorientierte Einführung in die Kausalanalyse mit Hilfe von AMOS, SmartPLS und SPSS. Berlin Heidelberg, Springer.

Whitby, M., Hodge, I., Lowe, P. and Saunders, C. (1996) Conservation options for CAP reform. $E \operatorname{COS} 17,46-55$.

Wilson, G.A. (1997) Factors Influencing Farmer Participation in the Environmentally Sensitive Areas Scheme. Journal of Environmental Management 50, 67-93.

Wilson, G. A. (1996) Farmer environmental attitudes and ESA participation. Geoforum 27, 115-131.

Wilson, G. A., and Hart, K. (2001) Farmer Participation in Agri-Environmental Schemes: Towards Conservation-Oriented Thinking? Sociologica Ruralis 41, 254-274.

Wilson, G. A., and Hart, K. (2000) Financial imperative or conservation concern? EU farmers' motivations for participation in voluntary agri-environmental schemes. Environment and Planning A 32, 2161-2185.

Winter, M. (2000) Strong policy or weak policy? The environmental impact of the 1992 reforms of the Common Agricultural Policy arable regime in Great Britain. Journal of Rural Studies 16, 47-59. 


\section{CHAPTER 3}

\section{I know what you fed last summer - Tracing back the dietary proportion of maize in cattle diet with ${ }^{13} \mathrm{C}$}

V. Hammes, O. Nüsse, J. Isselstein and M. Kayser 


\subsection{Abstract}

Cattle tail switch hair can serve as an isotopic archive - different sections of each hair contain information on diet from different time periods. We tested the reliability of ${ }^{13} \mathrm{C}$ signatures $\left(\delta^{13} \mathrm{C}\right)$ in cattle tail switch hair to retrospectively trace back the annual mean dietary proportion of maize of different production systems without having to sample and analyze the feed. Furthermore, we investigated if changes in the dietary proportion of maize during summer and winter feeding can be detected by sampling hair only once a year. We sampled tail switch hair and obtained information on management and annual mean diet compositions on 23 cattle farms in northern Germany. Farms differed in dietary proportions of maize, grass and concentrates as well as in grazing regime (year-round grazing, summer grazing, no grazing). We found that the mean $\delta^{13} \mathrm{C}$ signature of two hair sections that contain the isotopic information of summer and winter feeding $\left(\delta^{13} \mathrm{C}_{\text {Year }}\right)$ is a robust indicator for the annual mean proportion of maize in cattle diet. We could also reveal short term changes in the diet (when maize was added for some time) by analyzing the distribution of summer and winter $\delta^{13} \mathrm{C}$ signatures $\left(\delta^{13} \mathrm{C}_{\text {Season }}\right)$. Farms whose dietary proportion of maize deviated from the average dietary proportion of maize of the respective grazing regime (in summer or winter feeding) could be detected by analyzing

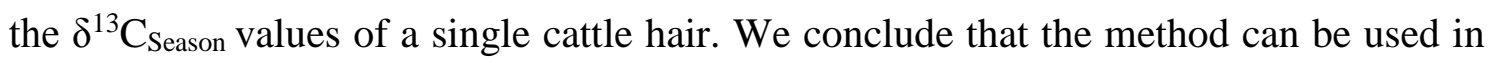
different cattle production systems to check on dietary proportions of maize for a period of one year before sampling of hair.

\subsection{Introduction}

The on-going trend to increasing milk yields requires higher energy contents in the diet that are often provided by silage maize and concentrates. Maize is comparably easy to cultivate at reasonable costs. Consequently, the area that is cultivated with maize for dairy production in Germany has increased during the last half century (Offermann et al., 2010; Reheul et al. 2015). Maize is often cultivated in intensive cattle production systems with $\mathrm{N}$ surpluses resulting in a potential risk for larger $\mathrm{N}$ emissions compared to grasslandbased forage production (Herrmann, 2013). The public interest in food production methods and the origin of food has been increasing over the last years (Gregory and Ingram, 2000; Opara and Mazaud, 2001; Bahar et al., 2005). In livestock production, pasture-based systems are regarded as more friendly for the environment, as promoting animal-welfare, and are thought to yield healthier products compared to non-grazing 
systems (Kelly et al., 1998; Aurousseau et al., 2004; Bedoin, 2012; Hocquette et al., 2012). However, most cattle farms, especially dairy, feed a mixture of grass silage, maize and concentrates in the daily diet of their animals. In practice, it is difficult to obtain detailed and reliable information on the feeding regimes on farms (Schüler et al. 2016; Becker et al. 2015). To verify the feeding regimes of farms, simple and robust indicators would be needed (Bockstaller et al., 1997; Halberg, 1999).

Isotopic analysis of different animal tissue has been used to evaluate food quality, to retrace animal feeding and to assess production systems in general in recent years (Knobbe et al., 2006; Karoui and Debaerdemaeker, 2007; Molkentin, 2009). It has been confirmed by isotope ratio mass spectrometry (IRMS) that the isotopic signature of cattle diet is transferred to animal tissue (Schwertl et al., 2005; Männel et al., 2007; Wittmer et al., 2010; Auerswald et al., 2011). In this respect, hair proved to be especially useful as it grows more or less continuously (Bullough and Laurence et al., 1958; O'Connell and Hedges, 1999; West et al., 2004; Schnyder et al., 2006) and can preserve isotopic information for many years (Touzeau et al., 2014). Thus, hair can serve as an isotopic archive recording dietary changes over time (e.g. White et al. 1999). Furthermore, sampling of hair is quick and easy and can be done without much disturbance to the animal (Schwertl et al., 2003).

The carbon isotopic signatures $\left(\delta^{13} \mathrm{C}\right)$ of $\mathrm{C}_{4}$ plants, such as maize, differ strongly from that of $\mathrm{C}_{3}$ plants (grasses, legumes, concentrates like soy or grain) (e.g. Knobbe et al., 2006) because of different photosynthetic pathways. Therefore, differences in the dietary proportion of $\mathrm{C}_{3}$ and $\mathrm{C}_{4}$ plants are related to the $\delta^{13} \mathrm{C}$ in cattle tissue (Smith and Epstein, 1971; Tieszen and Fagre, 1993; Kelly, 2001). The strong correlation of $\delta^{13} \mathrm{C}$ in cattle tissue and the dietary proportion of maize $\left(\mathrm{C}_{4}\right)$ has been shown in a number of studies (Kornexl et al. 1997; Schwertl et al. 2005; Bahar et al., 2005; Knobbe et al., 2006; Auerswald et al. 2015).

In this study, we used a two-step approach to test reliability of $\delta^{13} \mathrm{C}$ signature in cattle hair as a tool for tracing back the maize level in the feeding regime: in the first step we tested the reliability of the relationship of the annual mean $\delta^{13} \mathrm{C}$ signature in cattle hair $(\delta$ ${ }^{13} \mathrm{C}_{\text {Year }}$ ) and the annual mean proportion of maize that is fed in different cattle production systems. We hypothesize that

1) $\delta^{13} \mathrm{C}_{\text {Year }}$ in cattle hair of various cattle production systems in different regions in northern Germany can be used as a reliable indicator for the annual mean dietary proportion of maize in cattle diet. 
In the second step we tested whether the $\delta^{13} \mathrm{C}$ signatures of two different sections of the same cattle hair $\left(\delta^{13} \mathrm{C}_{\text {season }}\right)$ can be used to verify differences in dietary proportions of maize among grazing regimes (year-round grazing, summer grazing, no grazing) and to reveal short term diet changes. We hypothesize that

2) grazing regimes and differences among the dietary proportion of maize between seasons can be detected in a single cattle hair plucked in mid-March of the following year by analyzing $\delta^{13} \mathrm{C}_{\text {Season. }}$.

\subsection{Material and Methods}

\subsubsection{Sampling design}

We chose 23 cattle farms, mainly dairy but also suckler cows on the basis of two gradients (Tab. 3.1): 1) a location gradient (longitude, temperature, precipitation) and 2) a production intensity gradient characterized by the annual milk yield per cow per year and the stocking rate. For estimating the milk yield of suckler farms we used standard values from the literature (KTBL, 2009). Sampling of cattle hair was carried out in 2014 and obtained the isotopic information referred to cattle feeding in 2013.

To describe the feeding regime on the farms, we developed a questionnaire to be answered in face-to-face interviews with the farm managers. Farmers gave information on annual mean dietary proportions and grazing regimes for the year 2013 (Tab. 3.1). On all farms, maize is fed as the only $\mathrm{C}_{4}$ plant in cattle diet. The concentrates did not contain any $\mathrm{C}_{4}$ components, but consisted of soybean meal, sugar beet molasses, and wheat and barley seed. The dietary proportions of maize, grass and other concentrates differed substantially between suckler and dairy farms (Tab. 3.1). The farms could be assigned to three grazing regimes: year-round grazing, summer grazing (May-October), and no grazing. The breeds included Holstein, Deutsche Schwarzbunte, Deutsches Fleckvieh and Welsh Black. We assumed that cattle breed has no influence on the isotopic signatures in cattle hair which has been stated by Schwertl et al. (2003). Differences in $\delta^{13} \mathrm{C}$ signatures of silage, hay and fresh grass from temperate humid pasture are negligible (Schwertl et al. 2005).

Data on temperature and precipitation were obtained from the Clima Data Center (CDC) of the Deutsche Wetterdienst (DWD) (Tab. 3.2). 


\subsubsection{Study area and farms}

Our study area was located between $51^{\circ} 50^{\prime}$ to $53^{\circ} 05^{\prime}$ North and $8^{\circ} 19^{\prime}$ to $14^{\circ} 38^{\prime}$ East in northern Germany in an area called North German Plain (NGP). The NGP is a part of the geomorphic formation called North European Plain (NEP, elevation 0 to $200 \mathrm{~m}$ above sea level) which stretches from the Netherlands to Poland/Lithuania. To the South the NEP is confined by the Central European Highlands while to the west is the North Sea and to the east the Baltic Sea in the East. The climatic conditions range from sub-maritime conditions in the west to sub-continental conditions in the east.

All farms are located on sandy soils between 38 and $76 \mathrm{~m}$ above sea level. The mean annual precipitation in the year 2013 varied between 525 and $693 \mathrm{~mm}$ and mean annual air temperature ranged between 8.9 and $9.3{ }^{\circ} \mathrm{C}$ (Tab. 3.2).

Tab. 3.1: Details of the production systems of cattle farms in the survey on a gradient from west to east. $\mathrm{LU}=$ livestock unit, $500 \mathrm{~kg}$ of body weight; Lon = Longitude.

\begin{tabular}{|c|c|c|c|c|c|c|c|c|}
\hline \multirow[b]{2}{*}{ Farm } & \multirow[b]{2}{*}{ Lon[E] } & \multirow[b]{2}{*}{$\begin{array}{l}\text { Farm } \\
\text { type }\end{array}$} & \multirow[b]{2}{*}{$\begin{array}{l}\text { Grazing } \\
\text { regime }\end{array}$} & \multirow[b]{2}{*}{$\begin{array}{l}\text { Milk yield } \\
(\mathrm{kg} / \text { cow/ } \\
\mathrm{yr})^{*}\end{array}$} & \multicolumn{3}{|c|}{$\begin{array}{l}\text { Annual mean dietary } \\
\text { proportions (\% DM) }\end{array}$} & \multirow[b]{2}{*}{$\begin{array}{l}\text { Stocking rate } \\
\text { (LU/ha)* }\end{array}$} \\
\hline & & & & & Maize & $\begin{array}{l}\text { Grass } \\
\text { (pasture, } \\
\text { silage, hay) }\end{array}$ & $\begin{array}{l}\text { Concen } \\
\text { trates }\end{array}$ & \\
\hline $\mathrm{A}$ & 8.69 & Dairy & summer & 7300 & 0 & 71 & 29 & 0.6 \\
\hline B & 8.35 & Dairy & $\begin{array}{l}\text { no } \\
\text { grazing }\end{array}$ & 11212 & 39 & 36 & 25 & 0.9 \\
\hline $\mathrm{C}$ & 8.62 & $\begin{array}{l}\text { Suckler } \\
\text { cow }\end{array}$ & $\begin{array}{l}\text { year- } \\
\text { round }\end{array}$ & 2500 & 0 & 96 & 4 & 1.6 \\
\hline $\mathrm{D}$ & 8.33 & Dairy & summer & 9500 & 35 & 35 & 30 & 1.4 \\
\hline $\mathrm{E}$ & 8.64 & $\begin{array}{l}\text { Suckler } \\
\text { cow }\end{array}$ & $\begin{array}{l}\text { year- } \\
\text { round }\end{array}$ & 2500 & 0 & 100 & 0 & 1.0 \\
\hline $\mathrm{F}$ & 10.67 & $\begin{array}{l}\text { Suckler } \\
\text { cow }\end{array}$ & $\begin{array}{l}\text { year- } \\
\text { round }\end{array}$ & 2500 & 0 & 100 & 0 & 0.8 \\
\hline G & 10.30 & $\begin{array}{l}\text { Suckler } \\
\text { cow }\end{array}$ & $\begin{array}{l}\text { year- } \\
\text { round }\end{array}$ & 2500 & 0 & 98 & 2 & 0.6 \\
\hline $\mathrm{H}$ & 10.48 & Dairy & $\begin{array}{l}\text { no } \\
\text { grazing }\end{array}$ & 9600 & 53 & 27 & 20 & 1.9 \\
\hline I & 10.74 & Dairy & summer & 9000 & 36 & 36 & 28 & 0.3 \\
\hline $\mathrm{J}$ & 10.54 & Dairy & $\begin{array}{l}\text { no } \\
\text { grazing }\end{array}$ & 8800 & 35 & 45 & 20 & 2.5 \\
\hline K & 10.67 & Dairy & $\begin{array}{l}\text { no } \\
\text { grazing }\end{array}$ & 8845 & 39 & 17 & 44 & 2.0 \\
\hline $\mathrm{L}$ & 12.64 & Dairy & summer & 7300 & 54 & 29 & 17 & 0.7 \\
\hline M & 12.85 & $\begin{array}{l}\text { Suckler } \\
\text { cow }\end{array}$ & $\begin{array}{l}\text { year- } \\
\text { round }\end{array}$ & 2500 & 0 & 100 & 0 & 0.3 \\
\hline $\mathrm{N}$ & 12.09 & Dairy & $\begin{array}{l}\text { no } \\
\text { grazing }\end{array}$ & 8500 & 20 & 59 & 21 & 1.1 \\
\hline
\end{tabular}




\begin{tabular}{|c|c|c|c|c|c|c|c|c|}
\hline $\mathrm{O}$ & 12.74 & Dairy & $\begin{array}{l}\text { no } \\
\text { grazing }\end{array}$ & 7000 & 36 & 27 & 37 & 0.5 \\
\hline $\mathrm{P}$ & 12.14 & Dairy & $\begin{array}{l}\text { no } \\
\text { grazing }\end{array}$ & 9760 & 39 & 26 & 35 & 1.8 \\
\hline $\mathrm{Q}$ & 12.69 & $\begin{array}{l}\text { Suckler } \\
\text { cow }\end{array}$ & $\begin{array}{l}\text { year- } \\
\text { round }\end{array}$ & 2500 & 0 & 100 & 0 & 0.3 \\
\hline $\mathrm{R}$ & 13.87 & $\begin{array}{l}\text { Suckler } \\
\text { cow }\end{array}$ & $\begin{array}{l}\text { year- } \\
\text { round }\end{array}$ & 2500 & 0 & 98 & 2 & 0.4 \\
\hline S & 14.64 & Dairy & $\begin{array}{l}\text { no } \\
\text { grazing }\end{array}$ & 11266 & 45 & 20 & 35 & 0.5 \\
\hline $\mathrm{T}$ & 14.20 & Dairy & $\begin{array}{l}\text { no } \\
\text { grazing }\end{array}$ & 9870 & 50 & 25 & 25 & 0.5 \\
\hline $\mathrm{U}$ & 14.10 & Dairy & $\begin{array}{l}\text { no } \\
\text { grazing }\end{array}$ & 9550 & 55 & 19 & 26 & 0.6 \\
\hline V & 14.09 & Dairy & summer & 8870 & 64 & 0 & 36 & 0.2 \\
\hline W & 13.90 & Dairy & summer & 6200 & 31 & 53 & 16 & 1.2 \\
\hline
\end{tabular}

Tab. 3.2: Recorded variables, source and range; DWD = Deutscher Wetter Dienst, German Weather Service.

\begin{tabular}{|c|c|c|c|}
\hline Variable & Unit & Source & Range \\
\hline Grazing regime & & questionnaire & $\begin{array}{l}\text { 1) year-round grazing, } \\
\text { 2) summer grazing, } \\
\text { 3) no grazing }\end{array}$ \\
\hline Farm size (Agr. Land*) & ha & questionnaire & $20-3800$ \\
\hline Arable Land & ha & questionnaire & $0-3500$ \\
\hline Grassland area & ha & questionnaire & $8.3-450$ \\
\hline \multicolumn{4}{|l|}{ Precipitation: } \\
\hline Annual precipitation & $\mathrm{mm}$ & $\begin{array}{l}\text { Weather station } \\
\text { (DWD) }\end{array}$ & $525-693$ \\
\hline $\begin{array}{l}\text { Precipitation during } \\
\text { vegetation period, April- } \\
\text { October }\end{array}$ & $\mathrm{mm}$ & $\begin{array}{l}\text { Weather station } \\
\text { (DWD) }\end{array}$ & $351-482$ \\
\hline \multicolumn{4}{|l|}{ Temperature: } \\
\hline Annual mean temperature & ${ }^{\circ} \mathrm{C}$ & $\begin{array}{l}\text { Weather station } \\
\text { (DWD) }\end{array}$ & $8.9-9.3$ \\
\hline $\begin{array}{l}\text { Mean temperature during } \\
\text { vegetation period, April- } \\
\text { October }\end{array}$ & ${ }^{\circ} \mathrm{C}$ & $\begin{array}{l}\text { Weather station } \\
\text { (DWD) }\end{array}$ & $13.9-14.9$ \\
\hline $\begin{array}{l}\text { Length of vegetation } \\
\text { period }\end{array}$ & $\mathrm{d}$ & $\begin{array}{l}\text { Detection station } \\
\text { (DWD) }\end{array}$ & $171-179$ \\
\hline
\end{tabular}

*Agr. land =Agricultural land 


\subsubsection{Hair sampling and preparation}

The tail switch hair is the longest hair of cattle and is therefore best suited for detecting changes in diet over longer periods in the past (Schwertl et al., 2003). We plucked bundles of approximately 50 cattle tail switch hairs from two full grown, healthy animals of average productivity of each farm from March 10 to March 20, 2014. All sampled animals had been kept on the farm for more than 2 years before sampling. After sampling, the hairs were put in bags and were frozen for storage until further processing. We prepared the hair samples for stable isotope analysis according to Schwertl et al. $(2003 ; 2005)$. To remove contaminants, like traces of faeces, the hairs were soaked and washed by ultrasonication with deionized water, dried $\left(40{ }^{\circ} \mathrm{C}, 48 \mathrm{~h}\right)$, soaked in a $2: 1$ mixture of methanol/chloroform (approximately $2 \mathrm{~h}$ ), rinsed with deionized water, soaked in deionized water for another $30 \mathrm{~min}$, and rinsed again; finally, the hairs were dried again $\left(40{ }^{\circ} \mathrm{C}, 48 \mathrm{~h}\right)$.

\subsubsection{Position-time conversion and hair growth phases}

Mammal hair undergoes distinct phases of growth (anagen phase) and rest (telogen phase) (e.g. Alonso and Fuchs, 2006). For position-time conversion, that is to clearly assign a certain segment of the hair to a certain period of growth and the respective diet at that time, we need to know if the hair was in the growing or resting phase when plucked. In our study, we distinguished between anagen and telogen hair by microscopic examination as described by Van Scott et al. (1957) and Schwertl et al. (2003) and selected only three anagen hairs of similar length from each animal for further isotopic analysis.

For the interpretation of the isotopic analysis, we assumed a medium hair growth rate of $0.8 \mathrm{~mm} /$ day and the isotopic signal of a new diet after a diet switch to take 80 days to be clearly detectable in cattle hair (Jones et al., 1981; Fisher et al., 1985; Ayliffe et al., 2004; Schwertl et al., 2003; Schnyder et al., 2006; Zazzo et al., 2007; Osorio et al., 2011). This implies that each part of a hair can be assigned to an approximate period during which it had grown (Männel et al., 2007; Auerswald et al., 2011).

Cattle tail switch hair, especially of dairy cows, is regularly cut for hygienic reasons and hairs are often only about $10 \mathrm{~cm}$ long. We plucked hair in mid-March 2014 and chose the oldest hair section in order to get an isotopic signal from the previous summer that was as clear as possible. In fact, the sampling of the hair section that represented the summer period (9-11 cm from the hair base) has been a compromise between practical application and precision - sections from tail hair of at least $12 \mathrm{~cm}$ would have given an even clearer 
signal. In our study, the average length of suckler cow tail hair was $32.4 \mathrm{~cm}$ and that of dairy cow tail hair was $13.5 \mathrm{~cm}$; the shortest hair was $11.3 \mathrm{~cm}$.

The response of cattle hair to a dietary signal can be described by an exponential decay function (e.g. Schwertl et al., 2003). The diet of the last days before hair growth contributes the largest share to the signal of the newly grown hair section. Our selected section for the summer period therefore contains around $50 \%$ isotopic information of the summer - the grazing period (October, September) and another $50 \%$ of the winter period - the stable period (November).

In each cattle tail hair we selected four hair segments of $1 \mathrm{~cm}$ each (Fig. 3.1). For the summer period (August 2013) we chose the 9-11 cm section and for the winter period 2013 (November 2013) the 3-5 cm section. Each segment of $1 \mathrm{~cm}$ was cut with a stencil into even smaller pieces and put into a tin cup $(4 \times 6 \mathrm{~mm})$ for isotopic analysis.

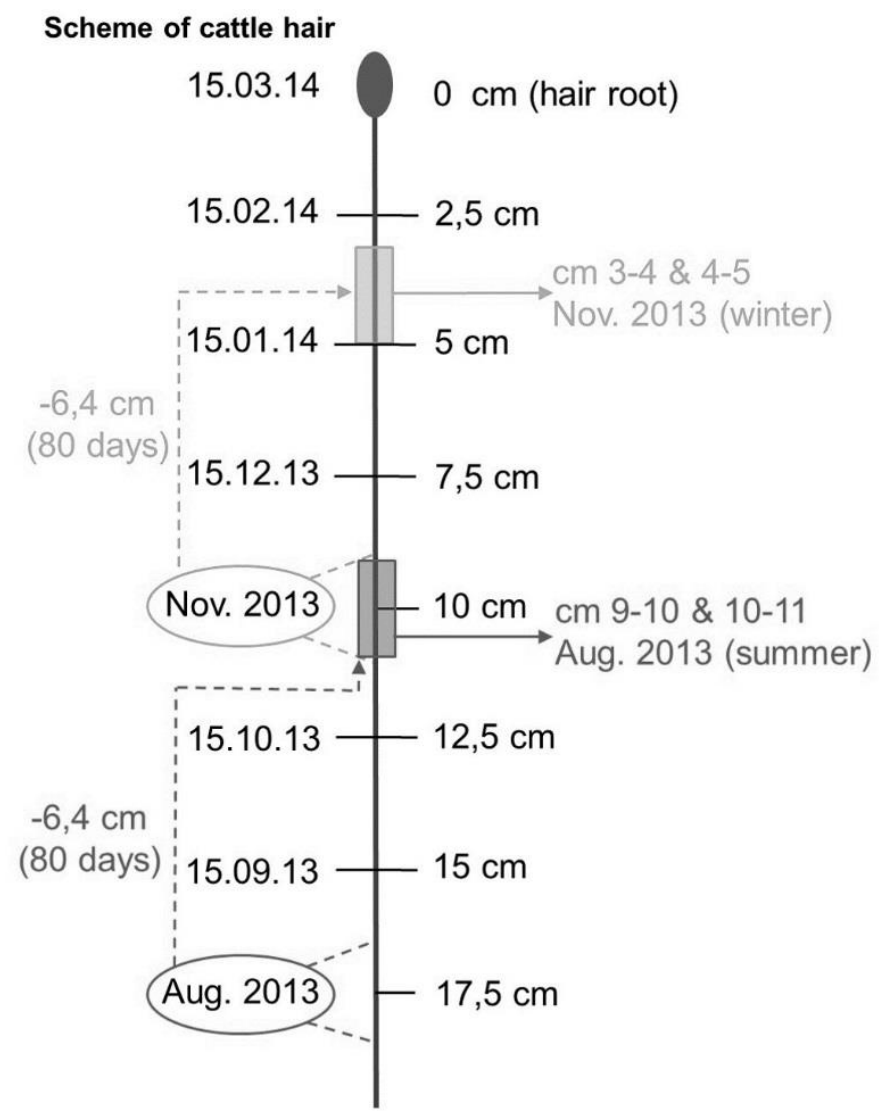

Fig. 3.1: Scheme of cattle hair plucked on March 15, 2014 showing hair sections that were analyzed for the winter (light grey) and summer period (dark grey).

\subsubsection{Isotopic analysis}

The isotopic analysis was carried out with an isotope ratio mass spectrometer Delta Plus IRMS linked with a Conflo III-Interface (Finnigan MAT, Bremen, Germany) to an 
elemental analyzer NA1110 (Carlo Erba Instruments, Milano, Italy). The isotope data are presented in parts per thousand (\%o) as $\delta^{13} \mathrm{C}(\%)$, with $\delta^{13} \mathrm{C}=\left[\left(\mathrm{R}_{\text {sample }} / \mathrm{R}_{\text {standard }}\right)-1\right] \times 10^{3}$ and $\mathrm{R}$ the ${ }^{13} \mathrm{C} /{ }^{12} \mathrm{C}$ ratio in the sample or standard (V-PDB, "Vienna Pee Dee Belemnite"). Each sample was measured against a secondary laboratory standard which had previously been calibrated against international standards (IAEA NBS18 and IAEA 600).

\subsubsection{Statistics}

In the first step, we looked for possible correlations amongst the parameters to get information on the structure of our dataset. To test for posible random effects we first used a linear mixed model (lmer4 package, R!) containing all data (that is all 552 values of all measured hair sections) with the factor 'dietary proportion of maize' as fixed factor and '(single) cow' and '(single) hair' as random factors. Afterwards we used a linear model based on the annual mean $\delta^{13} \mathrm{C}$ signatures of each farm (mean values of 4 sections of 3 hairs of 2 cows from each farm) to test the reliability of the relationship of the annual mean $\delta^{13} \mathrm{C}\left(\delta^{13} \mathrm{C}_{\text {Year }}\right)$ in cattle hair and the annual mean proportion of maize. To test the quality of the linear model we investigated the relationship between predicted and

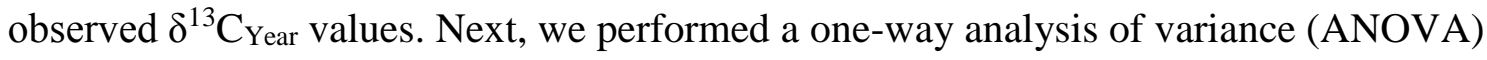
followed by a Tukey post hoc test to assess the differences in the seasonal mean $\delta^{13} \mathrm{C}$ signatures among the three grazing regimes and between summer and winter $\delta^{13} \mathrm{C}$ signatures $\left(\delta^{13} \mathrm{C}_{\text {Season }}\right)$ of the grazing regimes. We used box plots to indicate the variability within $\delta^{13} \mathrm{C}_{\text {Season }}$ values in the different grazing regimes as a basis for discussing outliers. All statistical analyses were conducted using the software R! version 3.2.1.

\subsection{Results and Discussion}

3.4.1 Correlations of $\delta^{13} \mathrm{C}_{\text {Year }}$ in cattle hair with cattle production system and location of the farms

The $\delta^{13} \mathrm{C}_{\text {Year }}$ values in cattle tail switch hair of each farm showed the highest correlation with the annual mean dietary proportion of maize (Tab. 3.3). The dietary proportions of grass and other concentrates were also correlated with ${ }^{13} \mathrm{C}_{\text {Year values because of the high }}$ intercorrelation of dietary components (Tab. 3.3). We did not find a correlation between

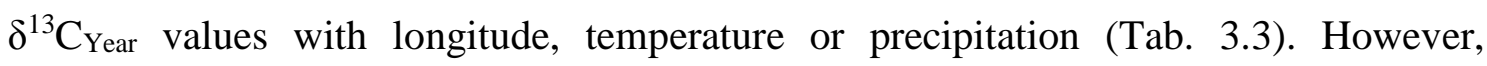
differences in temperature and precipitation might have added to the variability of the results. This matter is further discussed in section 3.4.3. 
Tab. 3.3: Correlation coefficients between $\delta^{13} \mathrm{C}_{\text {Year }}$ values of each farm and selected parameters of cattle production systems and location of the farms.

\begin{tabular}{|c|c|c|c|c|c|c|c|c|}
\hline & $\delta^{13} \mathrm{C}_{\text {Year }}$ & $\begin{array}{c}\text { Maize } \\
\text { in diet } \\
(\%)\end{array}$ & $\begin{array}{l}\text { Grass } \\
\text { in diet } \\
(\%)\end{array}$ & $\begin{array}{c}\text { Concentrates } \\
\text { in diet } \\
(\%)\end{array}$ & $\begin{array}{l}\text { Milk yield } \\
(\mathrm{kg} / \mathrm{cow} / \mathrm{yr})\end{array}$ & $\begin{array}{l}\text { Longitude } \\
\text { (E) }\end{array}$ & $\begin{array}{l}\operatorname{vegP} \\
(\mathrm{mm})\end{array}$ & $\begin{array}{l}\operatorname{veg} \mathrm{T} \\
\left({ }^{\circ} \mathrm{C}\right)\end{array}$ \\
\hline$\delta^{13} \mathrm{C}_{\text {Year }}$ & 1 & & & & & & & \\
\hline $\begin{array}{l}\text { Maize in diet } \\
(\%)\end{array}$ & 0.95 & 1 & & & & & & \\
\hline $\begin{array}{l}\text { Grass in diet } \\
(\%)\end{array}$ & 0.94 & -0.97 & 1 & & & & & \\
\hline $\begin{array}{l}\text { Concentrates } \\
\text { in diet } \\
(\%)\end{array}$ & 0.84 & 0.83 & -0.94 & 1 & & & & \\
\hline $\begin{array}{l}\text { Milk yield } \\
(\mathrm{kg} / \text { cow/yr) }\end{array}$ & 0.84 & 0.85 & -0.87 & 0.83 & 1 & & & \\
\hline $\begin{array}{l}\text { Longitude } \\
\text { (E) }\end{array}$ & 0.33 & 0.37 & -0.33 & 0.25 & 0.11 & 1 & & \\
\hline $\begin{array}{l}\text { vegP } \\
(\mathrm{mm})\end{array}$ & 0 & -0.05 & 0.02 & 0.02 & -0.09 & -0.17 & 1 & \\
\hline $\begin{array}{l}\text { vegT } \\
\left({ }^{\circ} \mathrm{C}\right)\end{array}$ & 0.14 & 0.22 & -0.20 & 0.16 & 0.04 & 0.84 & -0.36 & 1 \\
\hline
\end{tabular}

The annual dietary proportion of maize explained $89 \%(\mathrm{p}<0.001)$ of the variation in

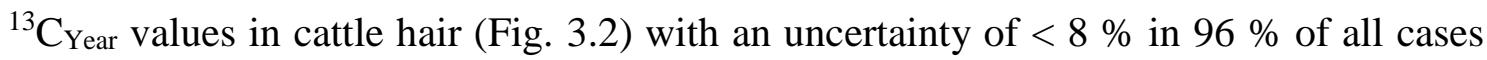
(Fig. 3.3). This finding confirms the close relationship between the dietary proportion of maize and $\delta^{13} \mathrm{C}$ in cattle hair that has also been found by Osorio et al. (2011), Zazzo et al. (2007) and Schwertl (2005).

Boner and Förstel (2004) investigated $\delta^{13} \mathrm{C}$ in beef from strict organic and conventional farms. The use of $\mathrm{C}_{4}$ plants is rather unusual in strict organic farming and they concluded that a $\delta^{13} \mathrm{C}$ in cattle hair of $-20 \%$ in beef is the limit for strict organic farming. A higher $\delta^{13} \mathrm{C}$ in cattle hair would be a clear sign for maize or other $\mathrm{C}_{4}$ plants in the diet.

Our model confirms that a ${ }^{13} \mathrm{C}_{\text {Year }}$ value in cattle hair higher than $-25.10 \%$ (95\% CI) is an indication for maize in the cattle diet of up to one year before hair sampling (Fig. 3.2). This is further confirmed by the fact that differences in $\delta^{13} \mathrm{C}$ of $\mathrm{C}_{3}$ plants from pastures can only lead to differences in $\delta^{13} \mathrm{C}$ in cattle hair in the range of $-25 \%$ o to $-27 \%$ (Schnyder et al., 2006). Also concentrates solely derived from $C_{3}$ plants have been found to result in similar or only slightly higher $\delta^{13} \mathrm{C}$ in cattle hair than $\mathrm{C}_{3}$ plants found in permanent pastures (Bahar et al. 2005). 


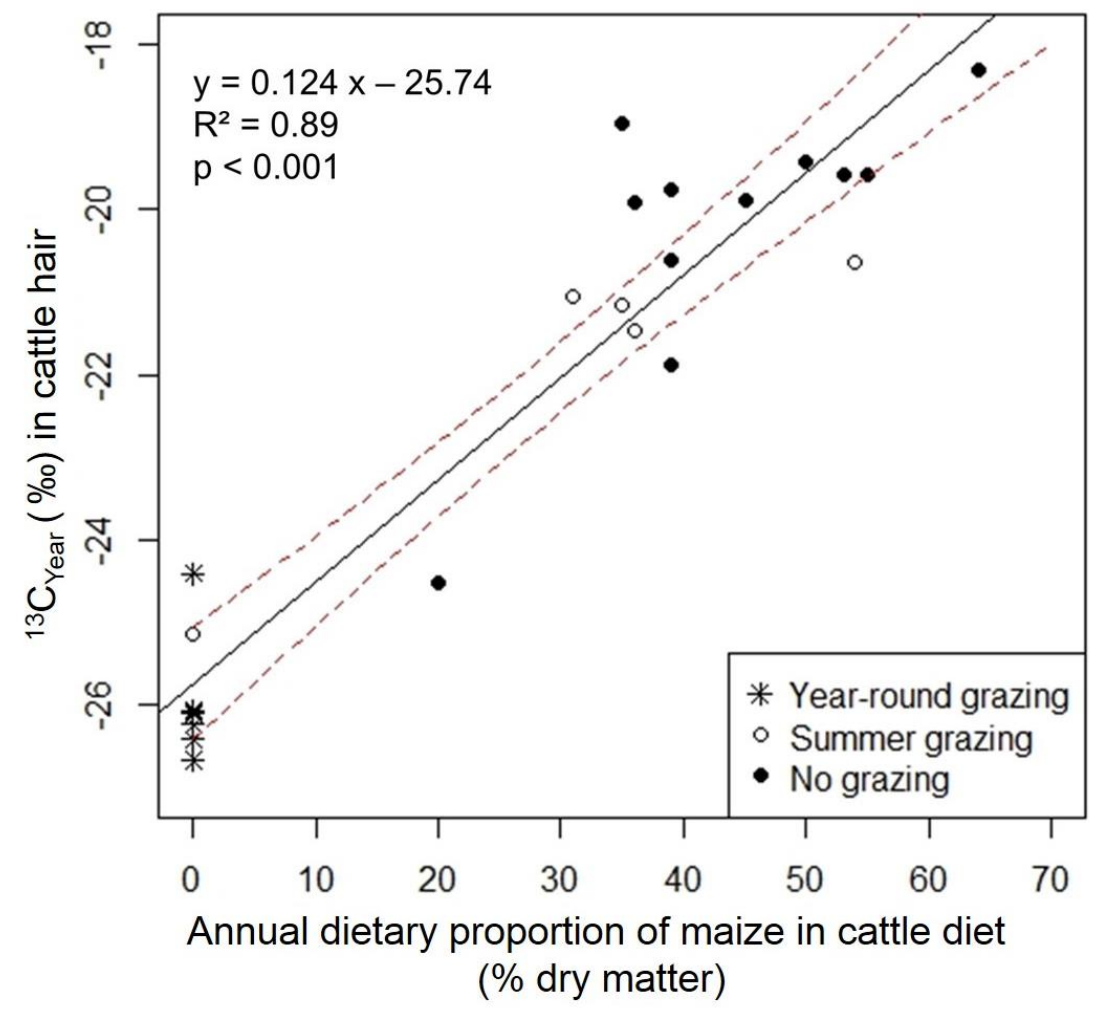

Fig. 3.2: Relationship between the annual mean dietary proportion of maize and the annual mean ${ }^{13} \mathrm{C}$ signature $\left({ }^{13} \mathrm{C}\right.$ Year $)$ in cattle hair. Each point refers to a farm. The solid and dotted lines refer to regression line and $95 \%$ confidence interval respectively.

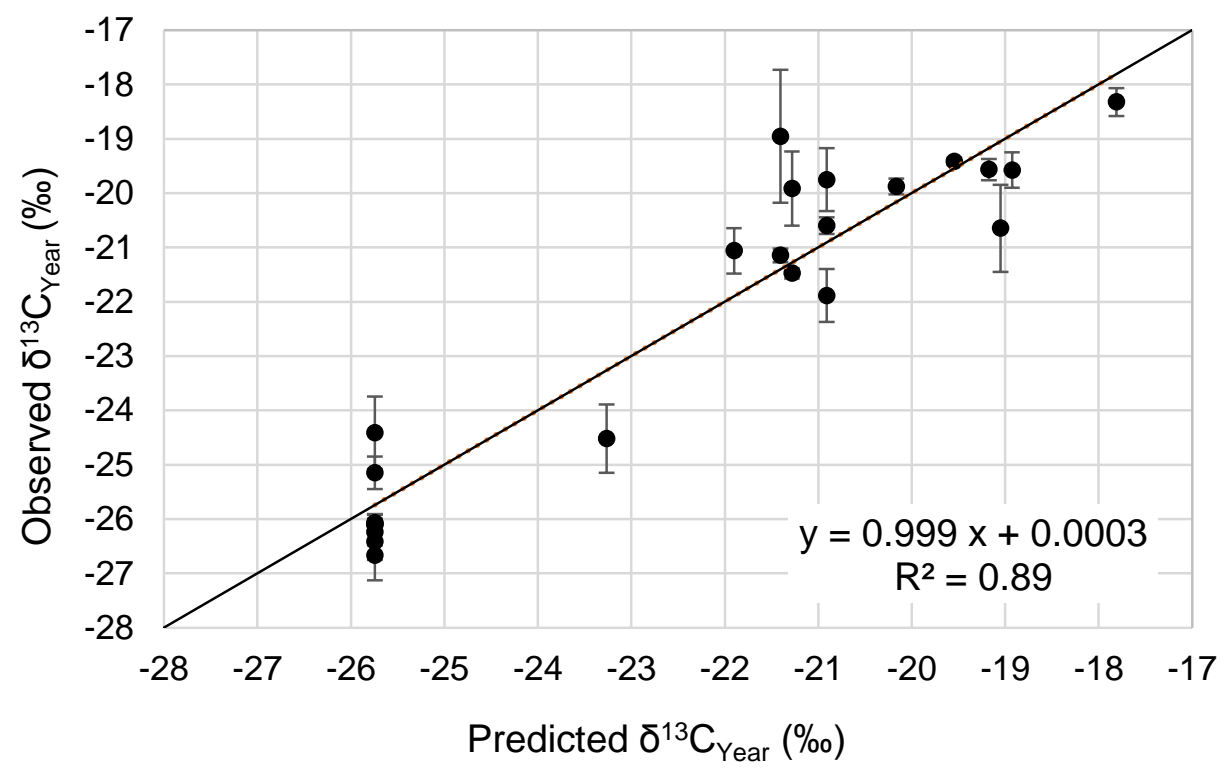

Fig. 3.3: Relationship of predicted and observed $\delta^{13} \mathrm{C}_{\text {Year }}$ with regression line and error bars for each farm. 
The results show that $\delta^{13} \mathrm{C}_{\text {Year }}$ in cattle hair of various cattle production systems in different regions in northern Germany can be used as a reliable indicator for the annual mean dietary proportion of maize in cattle diet. The ability to partly reconstruct diets within a certain time span in the past using $\delta^{13} \mathrm{C}$ in cattle hair is a valuable tool to check, for example, for maize or other $\mathrm{C}_{4}$ plants in feeding regimes that are supposed to be completely based on grass or are grazing-only dairy systems. Being able to estimate the amount of maize in the diet is already one step further than just distinguishing between grass-only systems and feeding systems that contain grass, maize and concentrates.

\subsubsection{Differences in $\delta^{13} \mathrm{C}_{\text {Season }}$ among grazing regimes}

There was a significant effect of the grazing regime on $\delta^{13} \mathrm{C}_{\text {Season }}(\mathrm{p}<0.001)$ while the effect of the season (summer and winter) and the interaction of grazing regime and season were not significant. ${ }^{13} \mathrm{C}_{\text {Season }}$ values in cattle hair of the three grazing regimes were: yearround grazing -26.00; summer grazing: -21.90 ; no grazing: -20.22 ; all means differed significantly from each other.

However, when we investigated the distribution of $\delta^{13} \mathrm{C}_{\text {Season }}$ for each grazing regime, we were able to identify farms whose summer or winter $\delta^{13} \mathrm{C}$ values deviated strongly from the mean seasonal $\delta^{13} \mathrm{C}$ value of the respective grazing regime (Fig. 3.4). The three outliers within the no grazing and summer grazing regime could be explained by the annual dietary proportions of maize of the respective farms that deviated strongly from the annual dietary proportions of maize of the respective grazing regime (farm A and farm $\mathrm{N}$; Fig. 3.4). The very high value in the winter $\delta^{13} \mathrm{C}$ values of the year-round grazing regime could also be explained by maize in the diet (Fig. 3.4, farm Q). In the interview at the time of sampling of the tail hairs, the farm manager of farm Q reported not to have fed maize in the previous year. However, after calling the farm manager again after data analysis and asking for a possible explanation of the high $\delta^{13} \mathrm{C}$ in cattle hair, he remembered having fed maize silage from a neighboring farm for some time during November 2013.

The two outliers of the summer $\delta^{13} \mathrm{C}$ values in the year-round grazing regime were below the $-25 \%$ - level and thus cannot be related to maize or other $\mathrm{C}_{4}$ plants in the diet (Schnyder et al. 2006; see section 3.4.1). Water availability can have an influence on $\delta^{13} \mathrm{C}$ of plants as well and that might have affected our results (e.g. Schnyder et al. 2006). However, we were not able to relate these two outliers in the summer $\delta^{13} \mathrm{C}$ in cattle hair 
to rainfall or temperature during the vegetation period. For a further discussion on unexplained variability in $\delta^{13} \mathrm{C}$ values in cattle hair see section 3.4.3.

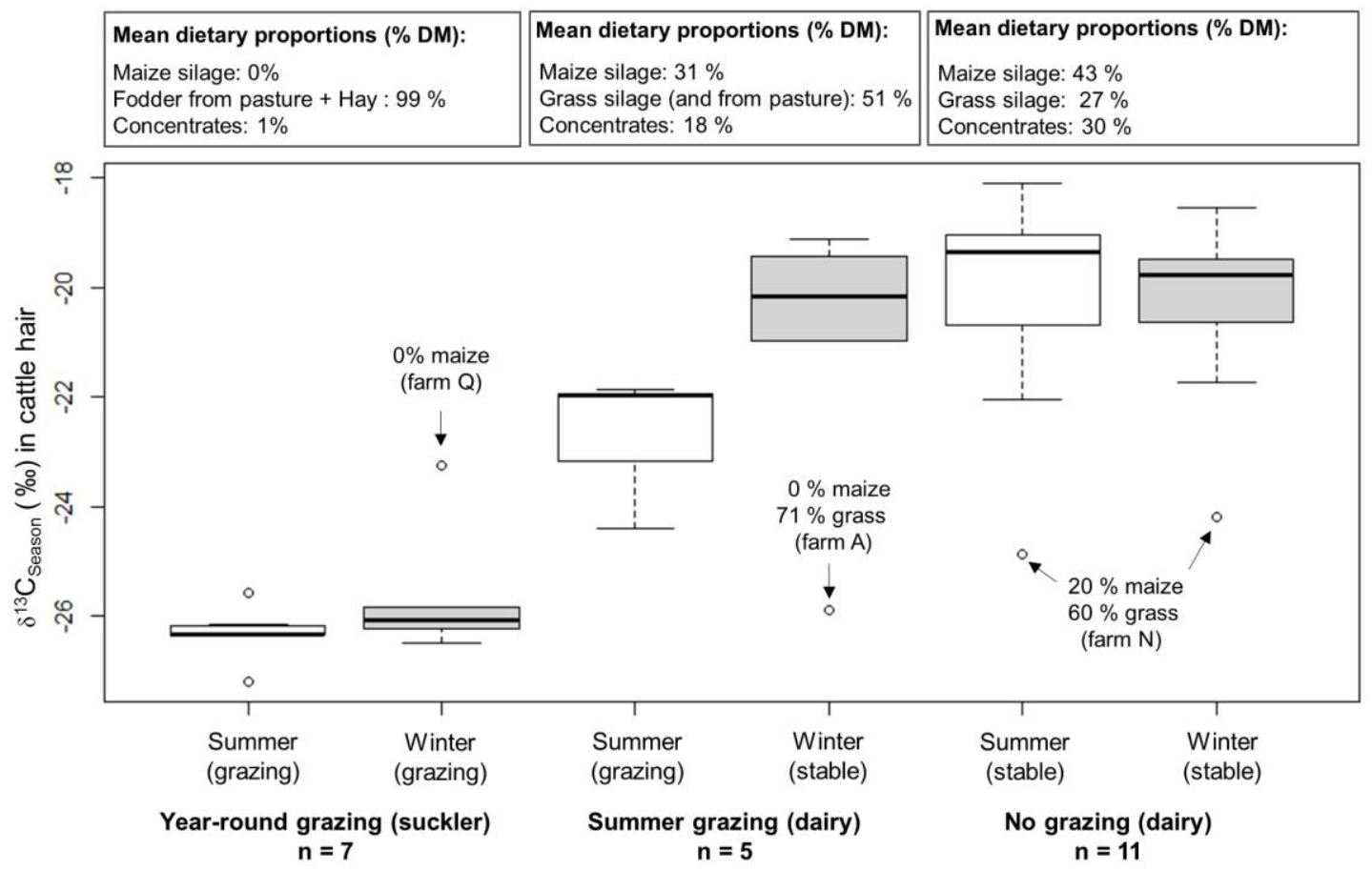

Fig. 3.4: $\delta^{13} \mathrm{C}$ values of cattle hair sections analyzed seperately for summer and winter periods of the three grazing regimes $\left(\delta^{13} \mathrm{C}_{\text {Season }}\right)$. Annual dietary proportion $(\%)$ of maize, grass and concentrates are indicated in the three boxes above each grazing regime. Circles indicate ourliers in the $\delta^{13} C_{\text {Season }}$ value distributions within each season of each grazing regime.

Analyzing outliers within the distribution of the $\delta^{13} \mathrm{C}_{\text {Season }}$ values of grazing regimes and seasons made it possible to detect farms that deviate from the average $\delta^{13} \mathrm{C}_{\text {Season }}$ of their respective grazing regime (Fig. 3.4). The fact that even a temporary change in diet

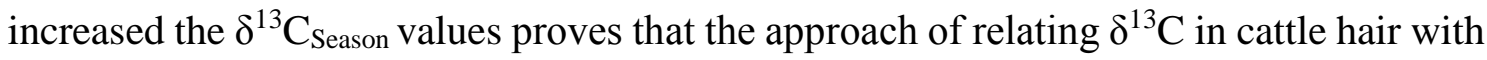
annual dietary proportions of maize is sensitive enough to detect short-term deviations. For horses, West et al. (2004) also found that short-term diet changes are detectable in hair even if the isotopic signal is weaker compared to signals that result from a permanent change of diet.

\subsubsection{Factors that can contribute to unexplained variance}

In our study, $89 \%$ of the variance in $\delta^{13} \mathrm{C}$ in cattle hair could be explained by the dietary proportion of maize. However, there is a range of other factors which possibly could contribute to the unexplained $11 \%$. Generally, plant communities that consist of $\mathrm{C}_{3}$ plants 
are sensitive to water availability and increasing precipitation results in reduced $\delta^{13} \mathrm{C}$ in cattle hair (e.g. Arens et al., 2000; Kaplan et al., 2002; Schnyder et al., 2006; Diefendorf et al., 2010; Klaus et al. 2013). Our study sites were chosen on a climatic gradient from sub-maritime to sub-continental $(420 \mathrm{~km})$. Differences in temperature and precipitation among our sites were in the range of $\Delta$-temp.: $0.4{ }^{\circ} \mathrm{C}$ and $\Delta$-precip.: $168 \mathrm{~mm}$. For an investigation of the possible effect of precipitation on $\delta^{13} \mathrm{C}$ in cattle hair we used data from farms which only fed $\mathrm{C}_{3}$ plants. We did not find any correlation between the annual precipitation or precipitation during the vegetation period and the mean $\delta^{13} \mathrm{C}$ in cattle hair, indicating an only weak effect in our sample on farms along our climatic gradient. Studies that report a significant influence of climatic parameters on $\delta^{13} \mathrm{C}$ in cattle hair of temperate grassland actually had more pronounced differences in temperature and precipitation among their sites, such as the study of Schnyder et al. (2006) with $\Delta$-temp. of $0.9{ }^{\circ} \mathrm{C}$ and $\Delta$-precip. of $436 \mathrm{~mm}$. Soil texture directly determines the amount of water in the soil that is available to plants (Klapp, 1971). The effect of soil conditions on $\delta^{13} \mathrm{C}$ values of $\mathrm{C}_{3}$ plants is even stronger than that of climatic factors (Schnyder et al. 2006). Therefore, although all farms were located on sandy soils, small differences in soil conditions like water retention could have contributed to the unexplained variance.

It is unlikely that the use of concentrates might have contributed decisively to the variation in $\delta^{13} \mathrm{C}$ in cattle hair. Studies on dairy farms that investigated the effect of concentrates from $\mathrm{C}_{3}$ plants on $\delta^{13} \mathrm{C}$ in cattle hair found very small differences in the isotopic signal (de Smet et al. 2004; Bahar et al. 2005; Schwertl et al. 2005; Osorio et al. 2011). Moreover, concentrates derived from $C_{3}$ plants and grass silage differ only very little in $\delta^{13} \mathrm{C}(<0.3 \%)$ (Bahar et al. 2005).

Some of the unexplained variance might also be related to inaccurate information on the composition of the cattle diet given by the farmer (Auerswald et al. 2015). This is important as it served as the sole basis for relating $\delta^{13} \mathrm{C}$ in cattle hair and maize in the diet. In our study we aimed at getting reliable information from the farmers by carefully preparing the interviews. We provided the relevant information of the survey to the farmers beforehand, we established a careful cross checking of data at all stages of data acquisition and analyses, and we contacted the farmers again in case of implausible data. 
3.4.4 Potential and limitations of using $\delta^{13} \mathrm{C}$ in cattle hair to check on reported dietary proportions of maize in practice - what to keep in mind

We investigated differences between summer and winter $\delta^{13} \mathrm{C}$ in cattle hair for 2013 by analyzing two centimeters of each anagen cattle hair sampled. The length of the tail hair, however, limits the time in the past from which the isotopic signal can be analyzed. To obtain clear isotopic information for the summer and winter period of the same year, the tail hair needs to be at least $12 \mathrm{~cm}$ long and plucking time no later than March 15 of the following year. If the plucking time is much later than March 15, the previous summer would not be covered; if the plucking time is much earlier, the hair would only contain isotopic information of the summer period but not of the winter period of that year. We found that differences between summer and winter $\delta^{13} \mathrm{C}$ in cattle hair were clearly detectable in our samples (Fig. 3.4). This was the case even though the hair section we analyzed for isotopic information from the summer section contained $50 \%$ information from the winter period as well. We conclude that differences in dietary proportion of maize (or $\mathrm{C}_{4}$ plants) between summer and winter periods can be revealed in a single cattle hair, even when it is only $11 \mathrm{~cm}$ in length.

\subsection{Conclusion}

We conclude that $\delta^{13} \mathrm{C}$ in cattle tail switch hair is a reliable tool to be used in practice to retrospectively estimate the annual dietary proportion of maize in the previous year without analyzing the feed components. $\delta^{13} \mathrm{C}$ in cattle hair proved to be a robust indicator that was not influenced by climatic conditions within the gradient of our study and the method can be applied to a range of cattle production systems. Sampling cattle tail hair of $>11 \mathrm{~cm}$ length in spring can provide two different sections containing information on $\delta 13 \mathrm{C}$ in cattle hair from the summer and winter period of the previous year. This information can be used to evaluate seasonal differences in the composition of feed $\left(\mathrm{C}_{3} / \mathrm{C}_{4}\right.$ plants) in different grazing regimes (year-round grazing, summer grazing, no grazing).

\subsection{Acknowledgments}

This project (Nachhaltiges Landmanagement im Norddeutschen Tiefland, FKZ 033L029) was supported by the German Federal Ministry of Education and Research (BMBF). We are grateful to Nicole Wrage-Mönnig (University of Rostock) and Barbara Hohlmann (University of Goettingen) for assistance with theoretical and practical questions concerning sampling and analysis. We would also like to take this opportunity to thank 
Reinhard Langel and colleagues from the Competence Centre Stable Isotopes (KOSI, University of Goettingen) for analysis of the isotope samples.

\subsection{References}

Alonso, L. and Fuchs, E. (2006) The hair cycle. Journal of Cell Science 119, 391-393.

Arens, N.C., Jahren, A. H. and Amundson, R. (2000) Can C 3 Plants Faithfully Record the Carbon Isotopic Composition of Atmospheric Carbon Dioxide? Paleobiology 26, 137-164.

Auerswald, K., Rossmann ,A., Schäufele, R., Schwertl, M., Monahan, F.J. and Schnyder, H. (2011) Does natural weathering change the stable isotope composition $(2 \mathrm{H}, 13 \mathrm{C}, 15 \mathrm{~N}, 18 \mathrm{O}$ and $34 \mathrm{~S})$ of cattle hair? Rapid Communications in Mass Spectrometry 25, 3741-3748.

Auerswald, K., Schäufele, R. and Bellof, G. (2015) Routing of Fatty Acids from Fresh Grass to Milk Restricts the Validation of Feeding Information Obtained by Measuring 13 C in Milk. Journal of Agricultural and Food Chemistry 63, 10500-10507.

Aurousseau, B., Bauchart, D., Calichon, E., Micol, D. and Priolo, A. (2004) Effect of grass or concentrate feeding systems and rate of growth on triglyceride and phospholipid and their fatty acids in the M. longissimus thoracis of lambs. Meat Science 66, 531-541.

Ayliffe, L. K. Cerling, T.E., Robinson, T., West, A.G., Sponheimer ,M., Passey, B.H., Hammer, J., Roeder, B., Dearing, M.D. and Ehleringer, J.R. (2004) Turnover of carbon isotopes in tail hair and breath $\mathrm{CO} 2$ of horses fed an isotopically varied diet. Oecologia 139, 11-22.

Bahar, B., Monahan, F. J., Moloney, A. P., O’Kiely, P., Scrimgeour, C. M., and Schmidt, O. (2005) Alteration of the carbon and nitrogen stable isotope composition of beef by substitution of grass silage with maize silage. Rapid Communications in Mass Spectrometry 19, 1937-1942.

Becker, T.H., Blume, L., Kayser, M. and Isselstein J. (2015) Development of a validity test for survey data on milk-from-grass from German dairy farms. Grassland Science in Europe 20, 84-86.

Bedoin, F. (2012) Grassland - based multifunctional beef production A farmer and food chain perspective. PhD Thesis, Aarhus University, Denmark.

Bockstaller, C., Girardin, P. and van der Werf, H.M. (1997) Use of agro-ecological indicators for the evaluation of farming systems. European Journal of Agronomy 7, 261-270.

Boner, M. and Förstel, H. (2004) Stable isotope variation as a tool to trace the authenticity of beef. Analytical and Bioanalytical Chemistry 378, 301-310. 
Bullough, W. S. and Laurence, E. B. (1958) The mitotic activity of the follicle. In Montagna W. and Ellis R. A. (eds.) The Biology of Hair Growth, New York, Academic Press, 1958, pp.171-187.

de Smet, S., Balcaen, A., Claeys, E., Boeckx, P. and van Cleemput, O. (2004) Stable carbon isotope analysis of different tissues of beef animals in relation to their diet. Rapid Communications in Mass Spectrometry 18, 1227-1232.

Diefendorf, A. F., Mueller, K. E., Wing, S. L., Koch, P. L. and Freeman, K. H. (2010) Global patterns in leaf 13C discrimination and implications for studies of past and future climate. Proceedings of the National Academy of Sciences 107, 5738-5743.

Fisher, D. D., Wilson, L. L., Leach, R. M., and Scholz, R. W. (1985) Switch hair as an indicator of magnesium and copper status of beef cows. American Journal of Veterinary Research 46, 2235-2240.

Gregory, P. and Ingram, J.S. (2000) Global change and food and forest production: future scientific challenges. Agriculture Ecosystem and Environment 82, 3-14.

Halberg, N. (1999) Indicators of resource use and environmental impact for use in a decision aid for Danish livestock farmers. Agriculture Ecosystem and Environment 76, 17-30.

Herrmann, A. (2013) Biogas production from maize: current State, challenges and prospects. 2. Agronomic and environmental aspects. Bioenergy Research 6, 372-387.

Hocquette, J.-F., Botreau, R., Picard, B., Jacquet, A., Pethick, D.W. and Scollan, N.D. (2012) Opportunities for predicting and manipulating beef quality. Meat Science $\mathbf{9 2}$, 197-209.

Jones, R. J., Ludlow, M. M., Troughton, J. H. and Blunt, C.G. (1981) Changes in the natural carbon isotope ratios of the hair from steers fed diets of $\mathrm{C} 4, \mathrm{C} 3$ and $\mathrm{C} 4$ species in sequence. Search 12, 85-87.

Kaplan, J.O., Prentice, I.C. and Buchmann, N. (2002) The stable carbon isotope composition of the terrestrial biosphere: Modeling at scales from the leaf to the globe. Global Biogeochemical Cycles 16, 8-1 - 8-11.

Karoui, R. and Debaerdemaeker, J. (2007) A review of the analytical methods coupled with chemometric tools for the determination of the quality and identity of dairy products. Food Chemistry 102, 621-640.

Kelly, M. L., Kolver, E. S., Bauman, D. E., van Amburgh, M. E. and Muller, L. D. (1998) Effect of Intake of Pasture on Concentrations of Conjugated Linoleic Acid in Milk of Lactating Cows. Journal of Dairy Science 81, 1630-1636.

Kelly, S. D. (2001) Development of analytical methods to determine the geographical origin of butter and cheese. Lipid Technology 13, 140-143. 
Klapp E (1971) Wiesen und Weiden. Verlag Paul Parey, Berlin.

Klaus, V.H., Hölzel, N., Prati, D., Schmitt, B., Schöning, I., Schrumpf, M., Fischer, M. and Kleinebecker, T. (2013) Organic vs. Conventional Grassland Management: Do 15N and 13C Isotopic Signatures of Hay and Soil Samples Differ? PLOS ONE 8, e78134.

Knobbe, N., VOGL, J., Pritzkow, W., Panne, U., Fry, H., Lochotzke, H. M. and PreissWeigert, A. (2006) $\mathrm{C}$ and $\mathrm{N}$ stable isotope variation in urine and milk of cattle depending on the diet. Analytical and Bioanalytical Chemistry 386, 104-108.

Kornexl, B.E., Werner, T., Roßmann, A. and Schmidt, H.-L. (1997) Measurement of stable isotope abundances in milk and milk ingredients - a possible tool for origin assignment and quality control. Zeitschrift für Lebensmittel-Untersuchung undForschung 205, 19-24.

Kuratorium für Technik und Bauwesen in der Landwirtschaft (KTBL) (2009): Faustzahlen für die Landwirtschaft, 14. Auflage, Darmstadt.

Männel, T.T., Auerswald, K. and Schnyder, H. (2007) Altitudinal gradients of grassland carbon and nitrogen isotope composition are recorded in the hair of grazers. Global Ecology and Biogeography 16, 583-592.

Molkentin, J. (2009) Authentication of Organic Milk Using $\delta 13 \mathrm{C}$ and the $\alpha$-Linolenic Acid Content of Milk Fat. Journal of Agricultural and Food Chemistry 57, 785-790.

O'Connell, T.C., and Hedges, R.E.E. (1999) Investigations into the effect of diet on modern human hair isotopic values. American Journal of Physical Anthropology 108, 409-425.

Offermann, F., Gömann, H., Kreins, P., von Ledebur, O., Pelikan, J., Salamon, P. and Sanders, J. (2010) vTI-Baseline 2009 to 2019: Agri-economic projections for Germany. Landbauforschung - vTI Agriculture and Forestry Research 60, 157-172.

Opara, L.U. and Mazaud, F. (2001) Food traceability from field to plate. Outlook on Agriculture 30, 239-247.

Osorio, M.T., Moloney, A.P., Schmidt, O. and Monahan, F.J. (2011) Beef Authentication and Retrospective Dietary Verification Using Stable Isotope Ratio Analysis of Bovine Muscle and Tail Hair. Journal of Agricultural and Food Chemistry 59, 3295-3305.

Reheul, D., Cougnon, M., de Cauwer, B., Swanckaert, J., Pannecoucque, J., D’hose, T., van den Nest, T., de Caesteker, E., Vaes, R., Peeters, A., Baert, J. and de Vliegher, A. (2015) Production potential of grassland and fodder crops in high-output systems in the Low Countries in north western Europe and how to deal with limiting factors. Grassland Science in Europe 20, 139-150.

Schüler, M., Laggner, B. and Osterburg, B. (2016) Effizienzbewertung unter Praxisbedingungen - Workflow zum Umgang mit ungenauen Daten auf Milchviehbetrieben in Niedersachsen. Tagungsband der 60. Jahrestagung der 
Arbeitsgemeinschaft Grünland und Futterbau (AGGF) vom 25. - 27. Aug. 2016: „Nachhaltige Milchproduktion: Forschung und Praxis im Dialog“. pp 23-26. Luxemburg.

Schwertl, M., Auerswald, K. and Schnyder, H. (2003) Reconstruction of the isotopic history of animal diets by hair segmental analysis. Rapid Communications in Mass Spectrometry 17, 1312-1318.

Schwertl, M., Auerswald, K., Schäufele, R. and Schnyder, H. (2005) Carbon and nitrogen stable isotope composition of cattle hair: ecological fingerprints of production systems? Agriculture, Ecosystems \& Environment 109, 153-165.

Schnyder, H., Schwertl, M., Auerswald, K. and Schäufele, R. (2006) Hair of grazing cattle provides an integrated measure of the effects of site conditions and interannual weather variability on $\delta 13 \mathrm{C}$ of temperate humid grassland. Global Change Biology 12 , $1315-1329$.

Smith, B.N. and Epstein, S. (1971) Two categories of 13C/12C ratios for higher plants. Plant Physiology 47, 380-384.

Tieszen, L.L. and Fagre, T. (1993) Effect of diet quality and composition on the isotopic composition of respiratory $\mathrm{CO} 2$, bone collagen, bioapatite, and soft tissues. In: Lambert J.B. and Grupe G. (eds.) Prehistoric human bone - archeology at the molecular level: New York, Springer-Verlag, p. 121-155.

Touzeau, A., Amiot, R., Blichert-Toft, J., Flandrois, J.-P., Fourel, F., Grossi, V., Martineau, F., Richardin, P. and Lécuyer, C. (2014) Diet of ancient Egyptians inferred from stable isotope systematics. Journal of Archaeological Science 46, 114-124.

van Scott, E.J., Reinertson, R.P. and Steinmuller, R. (1957) The Growing Hair Roots of the Human Scalp and Morphologic Changes Therein Following Amethopterin Therapy. Journal of Investigative Dermatology 29, 197-204.

West A.G., Ayliffe L.K., Cerling T.E., Robinson T.F., Karren B., Dearing M.D. and Ehleringer, J.R. (2004) Short-term diet changes revealed using stable carbon isotopes in horse tail-hair. Functional Ecology 18, 616-624.

White, C. D., Longstaffe, F. J. and Law, K. R. (1999) Seasonal stability and variation in diet as reflected in human mummy tissues from the Kharga Oasis and the Nile Valley. Palaeogeography Palaeoclimatology, Palaeoecology 147, 209-222.

Wittmer, M.H.O.M., Auerswald K., Schönbach, P., Schäufele, R., Müller, K., Yang, H., Bai, Y.F., Susenbeth, A., Taube, F. and Schnyder, H. (2010) Do grazer hair and faeces reflect the carbon isotope composition of semi-arid C3/C4 grassland? Basic and Applied Ecology 11, 83-92. 


\section{CHAPTER 4}

How an intensification of extensive grasslands on sandy soils affects yield, forage quality and other ecosystem services

Verena Hammes, Johannes Isselstein and Manfred Kayser

Manuscript prepared for submission 


\subsection{Abstract}

With the proceeding intensification of forage production systems many farmers broke up their permanent grassland and cultivated high-energy forages like ley grass and maize instead. In norther Germany, apart from the coastal marsh-regions, sandy soils with a low water holding capacity and nutrient retention functions prevail. The aim of this study was to investigate the potentials and risks of land-use intensification on former extensively managed permanent grassland sites on sandy soils for yield, forage quality and other ecosystem services. We set up a three-year field experiment with four management intensity levels representing four typical forage production systems (moderate permanent grassland, intensive permanent grassland, ley grass, maize) on five sites on a climatic gradient (temperature and precipitation) in northern Germany. We found that ley grass had no higher $\mathrm{N}$ yields and crude protein concentrations than intensive permanent grassland. Intensive permanent grassland had higher $\mathrm{N}$ yields than moderate permanent grassland while the number of plant species was not lower. Of all treatments, intensive permanent grassland was least influenced by site and year effects on yield, forage quality and species number. The dry matter yields of all grassland treatments were small, but forage had good net energy contents and crude protein concentrations. Dry matter yields of maize were in a range of those of the farming practice in the respective regions, but nutritional quality was poor. Maize showed a higher risk of nitrogen leaching compared to the grassland treatments. We conclude that to avoid a loss of ecosystem services and to have a forage production system that delivers yields of adequate quality, a moderate or intensive management of permanent grassland can be a good option on sandy soils.

\subsection{Introduction}

Grassland farming plays an important role among the agricultural production systems in Germany. The proportion of grassland ranges from 20 to over $30 \%$ of the agricultural land on a federal state level (Statistisches Bundesamt, 2008; Smit et al., 2008).

Extensively or moderately managed permanent grasslands deliver biomass for livestock and energy production and also provide ecosystem services like biodiversity and wildlife protection, carbon sequestration, water purification, nutrient retention and also social benefits like recreation (e.g. Hopkins et al., 2002).

In the last decades, however, forage production in cattle production systems has been intensified all throughout Europe. The on-going trend of increasing milk yields requires 
high energy forage with high energy contents which can be provided by intensive permanent grassland management, ley grass and silage maize cultivation (e.g. Taube and Conijn, 2007). The area cultivated with maize has increased drastically in Germany during the last half century (Offermann et al., 2010; Reheul et al., 2015) often at the expense of permanent grassland. This process leads to increasing trade-offs because intensive forage crop production is accompanied by the loss of other ecosystem service functions (Tilman, 2001; Thébault et al., 2014; Allan et al., 2015; Allan et al., 2014).

In northern Germany, a great amount of grassland on freely draining sandy soils has been ploughed in recent years to cultivate ley grass or maize (Wachendorf and Taube, 2002) to increase the production intensity.

In this study we wanted to find out how yield and forage quality ( $\mathrm{N}$ yield, crude protein concentration, energy content) and other ecosystem service parameters (species richness, nitrogen use efficiency, soil mineral nitrogen) of different grassland systems are influenced by a gradual intensification of the system. We investigated four management intensity levels of forage production (moderate permanent grassland, intensive permanent grassland, ley grass, maize) on five sites on sandy soils along a climatic gradient (temperature \& precipitation) in northern Germany. Our hypothesis is that, despite the unfavorable soils conditions, an adapted management intensity of grassland management can lead to adequate yields and forage qualities while ecosystem services like phytodiversity and nutrient retention are preserved.

\subsection{Material and Methods}

\subsubsection{Study area}

The five experimental sites (Diepholz, Heidekreis, Uelzen, Fläming, Oder-Spree) were located on an west-east gradient between $51^{\circ} 50^{\prime}$ to $53^{\circ} 05^{\prime}$ North, and $8^{\circ} 19^{\prime}$ to $14^{\circ} 38^{\prime}$ East in northern Germany in an area called North German Plain (NGP), one of Germany's major geographical regions. The NGP is a part of the geomorphic formation North European Plain (NEP, elevation 0 to $200 \mathrm{~m}$ above sea level) which stretches from the Netherlands to Poland/Lithuania. In the South, it is confined by the Central European Highlands while bordered by the North Sea in the western part and the Baltic Sea in the East. The climatic conditions in the survey area range from sub-maritime conditions in the west to sub-continental conditions in the east, with warmer and dryer summers in the 
eastern regions. All sites are located on sandy soils with similar soil conditions (loamy sand to sandy loam, ss-ls) between 38 and $76 \mathrm{~m}$ above sea level.

All sites were extensively managed grassland (at least for the previous five years) with not more than two cuts per year and less than $100 \mathrm{~kg} \mathrm{~N}$ ha/year.

Before starting the experiment, Magnesium (Mg), P (Phosphorus), Potassium (K) and pH-values were tested on all sites in 0-10 and 0-30 cm soil depth in March 2012 (Tab. 4.1). Soil mineral nitrogen was tested in October of each year in $0-30 \mathrm{~cm} . \mathrm{Mg}$ and $\mathrm{K}$, were analyzed by atomic absorption spectrometry (ASS) and P was analyzed photometrically by an automatic analyzer (Eppendorf). For soil mineral nitrogen (SMN; sum of $\mathrm{NO}_{3}-\mathrm{N}$ and $\mathrm{NH}_{4}-\mathrm{N}$ ) samples were taken on all sites; sampling depth was $0-30 \mathrm{~cm}$. After extraction with a $0.0125 \mathrm{M} \mathrm{CaCl}_{2}$ solution, the nitrate and ammonium concentrations in the filtered solution were measured photometrically by flow injection analysis (FIA).

All sites received fertilizer to adjust initial soil nutrient concentrations before starting the experiment. The sites in Diepholz, Heidekreis and Uelzen were limed in April to adjust the initial $\mathrm{pH}$ to average.

Tab. 4.1: Long-term temperature and precipitation dates on observation sites (arranged from west to east) among 1991-2010 and soil mean values $(0-30 \mathrm{~cm})$ of Magnesium $(\mathrm{Mg})$, Potassium (K), Phosphorus (P) (mg/100g) and $\mathrm{pH}$-values of each site before staring the experiment.

\begin{tabular}{rrrrrrr}
\hline Site & $\begin{array}{r}\text { Annual mean } \\
\text { temperature } \\
(1991-2010)\end{array}$ & $\begin{array}{r}\text { Precipitation } \\
\text { annual sum } \\
(1991-2010)\end{array}$ & $\mathbf{M g}$ & $\mathbf{K}$ & $\mathbf{P}$ & $\mathbf{p H}$ \\
& ${ }^{\circ} \mathrm{C}$ & $\mathrm{mm}$ & $\mathrm{mg} / \mathrm{kg}$ & $\mathrm{mg} / \mathrm{kg}$ & $\mathrm{mg} / \mathrm{kg}$ & \\
\hline Diepholz & 9.8 & 706.1 & 46 & 39 & 83 & 4.6 \\
Heidekreis & 9.1 & 757.9 & 50 & 30 & 17 & 4.7 \\
Uelzen & 9.2 & 726.7 & 47 & 45 & 95 & 4.3 \\
Fläming & 9.8 & 571.9 & 104 & 69 & 48 & 5.4 \\
Oder-Spree & 9.6 & 584.9 & 80 & 55 & 85 & 5.7 \\
\hline
\end{tabular}

\subsubsection{Experimental Set up}

We set up a three-year field experiment with a two-factorial design: there were five sites along a climatic gradient and four treatments on an intensity gradient represented by a combination of increasing $\mathrm{N}$ input, cutting frequency and transformation to ley grass or maize - level 1 and 2: increasing $\mathrm{N}$ input and cutting frequency on permanent grassland; level 3 and 4: ploughing of existing sward with cultivation of ley grass (level 3) and maize (level 4) (Tab. 4.2). 
Tab. 4.2: Experimental design.

\begin{tabular}{|c|c|c|c|}
\hline \multirow[b]{2}{*}{ Factor } & \multirow[b]{2}{*}{ Factor Levels } & \multicolumn{2}{|c|}{ Management } \\
\hline & & $\begin{array}{l}\text { Cutting } \\
\text { frequency }\end{array}$ & $\begin{array}{l}\text { Amount and partitioning } \\
\text { of } \mathrm{N} \text { application }(\mathrm{kg} \mathrm{N} \\
\text { ha'yr) }\end{array}$ \\
\hline 1. Site & $\begin{array}{l}\text { 1. Diepholz (DH) } \\
\text { 2. Heidekreis (HK) } \\
\text { 3. Uelzen (UE) } \\
\text { 3. Fläming (FL) } \\
\text { 5. Oder-Spree (OS) }\end{array}$ & & \\
\hline \multirow[t]{4}{*}{ 2. Treatment } & $\begin{array}{l}\text { 1. Moderate permanent grassland } \\
\text { (PGM) - Level } 1\end{array}$ & 2 & $80(50 / 30)$ \\
\hline & $\begin{array}{l}\text { 2. Intensive permanent grassland } \\
\text { (PGI) - Level } 2\end{array}$ & 4 & $240(80 / 60 / 60 / 40)$ \\
\hline & $\begin{array}{l}\text { 3. Conversion of permanent grassland; } \\
\text { Ley grass } \\
\text { (Ley) - Level } 3\end{array}$ & 4 & $340(110 / 90 / 80 / 60)$ \\
\hline & $\begin{array}{l}\text { 4. Conversion of permanent grassland; } \\
\text { Maize } \\
\text { (Maize) - Level } 4\end{array}$ & (1) & $160(80 / 80)$ \\
\hline
\end{tabular}

There were four treatments in a randomized block designs with three replications resulting in 12 plots per site and a total of 60 plots; s each plot had a size of $15 \mathrm{~m}^{2}(3 \mathrm{~m} \mathrm{x}$ $5 \mathrm{~m})$.

The maize treatments were ploughed in April in each year and silage maize (variety: Ambrosini, FAO 215) planted with 8 seeds per $\mathrm{m}^{2}$ maize. The ley grass treatments were ploughed only in April 2012 and sown with a ley grass mixture (Seed mixture A3, $29 \%$ Lolium multiflorum, variety: "Gisel"; 29 \% Lolium hybridum, variety "Enduro"; 42\% Lolium perenne, varieties: $21 \%$ "Limbos" and $21 \%$ "Zocalo"). Before ploughing the original grass sward had been killed with an herbicide (glypgosate).

Intensive permanent grassland and ley grass were cut four times a year: in mid-Mai, early July, end of August, and mid-October. Moderate grassland was cut twice a year: in early July and in mid-October. Maize was harvested at the end of September.

All treatments were fertilized with potassium, magnesium, and phosphate in mid-March of each year. The grassland-plots (PGM, PGI, Ley) received nitrogen in form of calcium ammonium nitrate (CAN) in mid-March and after each cut except for the last cut of the year (see Tab. 4.2). Maize-plots were fertilized with nitrogen in early July (see Tab. 4.2). Weeds in maize were controlled by herbicides and weeding by hand. 


\subsubsection{Data sampling and measurement}

Before each harvest of the grass treatments (PGM, PGI, Ley) two randomly chosen samples were taken in an area of $1 \mathrm{~m}^{2}$. The standing biomass was cut at a height of $5 \mathrm{~cm}$ with garden scissors and herbage mass was weighed. Subsamples (500 g) were then taken from the cut material and oven-dried at $60{ }^{\circ} \mathrm{C}$ for $48 \mathrm{~h}$ to determine dry matter (DM) content.

Before harvesting the maize in mid- to end-September each year, 40 plants per plot were cut manually, the biomass weighed and maize plants chopped with a branch cutter. From the chopped material subsamples (500 g) were taken and oven-dried at $60{ }^{\circ} \mathrm{C}$ for $48 \mathrm{~h}$ to determine dry matter (DM) content.

Dried biomass samples were ground in a mill $(1 \mathrm{~mm})$ and analyzed by near-infrared spectroscopy (NIRS) for forage quality parameters. Energy content (NEL) was calculated in accordance with the German Society of Nutrition Physiology (GfE, 2004, 2008, 2009). Nitrogen use efficiency (NUE) was calculated as described in Brentrup and Palliere (2010).

All higher plant species were recorded in all 12 plots on all 5 sites in July 2013.

Data on temperature and precipitation (monthly averages) were collected from the Climate-Data Center (CDC) of the German Weather Service (Deutscher Wetterdienst, DWD).

\subsubsection{Statistics}

We used a linear mixed effects model (lme4 package, R!) with the factors 'Treatment', 'Site' and 'Year' in die fixed effects term and 'Block' in the random effects term. We also tested for interactions between factors. Differences between treatments in each observation year were analyzed by a one-way analysis of variances (ANOVA) followed by pair-wise comparisons of means using a Tukey HSD post hoc test. Non normal distributed data were rank transformed before applying parametric methods. All statistical analyses were conducted using the software R! version 3.2.2. 


\subsection{Results and Discussion}

Cultivating maize on unfavorable soil conditions is common agricultural praxis as maize is generally thriving under all circumstances. In north-western Europe maize is often cultivated on sandy soils, usually as feed for livestock or for biogas production - yields are high when there is sufficient water and nitrogen (Pammer and Ranninger, 1928; Kayser et al., 2011). In contrast, economic grassland management on sandy soils is more challenging. The effectiveness of grassland fertilization depends on the type of meadow concerned (Müller, 1953). Site conditions and plant species compositions have a large influence on the way in which a certain grasslands should be managed. As yield and forage quality and also ecosystem service functions of forage crop production systems and especially of grasslands vary with site conditions like soil type and climatic conditions (Wilson, 1982; Buxton and Casler, 1993; Buxton and Fales, 1994) also the trade-offs between productivity and the loss of other ecosystem services can vary. In the following section we will first present and discuss the effect of the intensity level of the forage production system in combination with year and site effects on yield and forage as well as ecosystem service parameters of the different forage production systems. In a second step, we will discuss advantages and disadvantage of the intensification of the forage production system and how to minimize the trade-offs between yield, forage quality and the preservation of other ecosystem services.

4.4.1 Differences in yield, forage quality and other ecosystem service parameters among treatments, sites and experimental years

The treatment effect (intensity) was usually stronger than that of site or year. The site effect was smaller than the year effect (Tab. 4.3). The interaction of treatment and year was strong for all parameters while the interaction of treatment and site was comparably weak (Tab. 4.3). 
Tab. 4.3: Results of ANOVA evaluating effects of Treatment, Site and Year on Yield, forage quality and other ecosystem service parameters. $* * *=p<0.001 ; * *=p<0.01$.

\begin{tabular}{|c|c|c|c|c|c|c|c|}
\hline & $\begin{array}{l}\text { Dry } \\
\text { matter } \\
\text { yield }\end{array}$ & $\begin{array}{l}\mathrm{N} \\
\text { yield }\end{array}$ & $\begin{array}{l}\text { Energy } \\
\text { content }\end{array}$ & $\begin{array}{l}\text { Crude } \\
\text { protein } \\
\text { concentration }\end{array}$ & $\begin{array}{l}\text { Nitrogen } \\
\text { use } \\
\text { efficiency }\end{array}$ & $\begin{array}{l}\text { Soil } \\
\text { mineral } \\
\text { nitrogen } \\
\end{array}$ & $\begin{array}{l}\text { Plant } \\
\text { Species } \\
\text { richness }\end{array}$ \\
\hline \multicolumn{8}{|l|}{ Treatment } \\
\hline $\begin{array}{l}F \text { value } \\
P \text { value }\end{array}$ & $\begin{array}{l}333.07 \\
* * *\end{array}$ & $\begin{array}{l}35.32 \\
* * *\end{array}$ & $\begin{array}{l}28.09 \\
* * *\end{array}$ & $\begin{array}{l}915.25 \\
* * *\end{array}$ & $\begin{array}{l}228.95 \\
* * *\end{array}$ & $\begin{array}{l}20.27 \\
* * *\end{array}$ & $\begin{array}{l}21.58 \\
* * *\end{array}$ \\
\hline \multicolumn{8}{|l|}{ Site } \\
\hline F value & 25.65 & 33.17 & 7.28 & 11.26 & 29.20 & 1.80 & 4.20 \\
\hline$P$ value & $* * *$ & $* * *$ & $* * *$ & $* * *$ & $* * *$ & ns & $* *$ \\
\hline \multicolumn{8}{|l|}{ Year } \\
\hline $\mathrm{F}$ value & 22.47 & 73.86 & 13.67 & 44.48 & 62.93 & 15.76 & -- \\
\hline$P$ value & $* * *$ & $* * *$ & $* * *$ & $* * *$ & $* * *$ & $* * *$ & -- \\
\hline \multicolumn{8}{|l|}{ Treatment : Site } \\
\hline F value & 7.74 & 4.42 & 6.32 & 7.36 & 5.22 & 3.35 & 3.55 \\
\hline $\mathrm{P}$ value & $* * *$ & $* * *$ & $* * *$ & $* * *$ & $* * *$ & $* * *$ & $* *$ \\
\hline \multicolumn{8}{|l|}{ Treatment : Year } \\
\hline $\mathrm{F}$ value & 4.86 & 38.84 & 16.18 & 57.18 & 28.42 & 16.23 & -- \\
\hline$P$ value & $* * *$ & $* * *$ & $* * *$ & $* * *$ & $* * *$ & $* * *$ & -- \\
\hline \multicolumn{8}{|l|}{ Site : Year } \\
\hline F value & 10.09 & 19.17 & 10.32 & 20.25 & 16.95 & 6.45 & -- \\
\hline$P$ value & $* * *$ & $* * *$ & $* * *$ & $* * *$ & $* * *$ & $* * *$ & -- \\
\hline \multicolumn{8}{|l|}{$\begin{array}{l}\text { Treatment : Site : } \\
\text { Year }\end{array}$} \\
\hline F value & 6.59 & 3.26 & 2.66 & 10.43 & 3.23 & 2.58 & -- \\
\hline$P$ value & $* * *$ & $* * *$ & $* * *$ & $* * *$ & $* * *$ & $* * *$ & -- \\
\hline Multiple $\mathbf{R}^{2}$ of model & 0.92 & 0.89 & 0.80 & 0.97 & 0.92 & 0.75 & 0.76 \\
\hline P Value & $* * *$ & $* * *$ & $* * *$ & $* * *$ & $* * *$ & $* * *$ & $* * *$ \\
\hline
\end{tabular}

The differences among sites did not correlate with climatic parameters along the westeast gradient (data not shown). However, the climatic conditions in the experimental years differed substantially from the long-term average (compare Tab. 4.1, Tab. 4.5). There are other interactions of environmental site conditions and management apart from climatic parameters that might have caused the differences among the sites (Neuwirth and Hofer, 2013; Käding et al., 2005). Although all sites had similar cultivation history - they had been extensively used as permanent grassland with a maximum of $100 \mathrm{~kg} \mathrm{~N} / \mathrm{ha}-$ differences in the initial soil conditions (see Tab. 4.1) might have influenced the results to a certain extent. Especially the supply with $\mathrm{P}$ and $\mathrm{K}$ and lime $(\mathrm{pH})$ would have altered the soil fertility. 
Tab. 4.4: Differences in yield, forage quality and other ecosystem service parameters of treatments among years. Letters indicating significant differences among years (colums).

\begin{tabular}{|c|c|c|c|c|c|}
\hline Parameter & Treatment (Intensity Level) & 2012 & 2013 & 2014 & P value \\
\hline $\begin{array}{l}\text { Dry matter } \\
\text { yield } \\
\text { (t/ha) }\end{array}$ & $\begin{array}{l}\text { Moderate permanent grassland } \\
\text { Intensive permanent grassland } \\
\text { Ley grass } \\
\text { Maize* }\end{array}$ & $\begin{array}{l}4.42 \\
5.30 \\
3.64 \mathrm{a} \\
13.15\end{array}$ & $\begin{array}{l}5.41 \\
5.60 \\
7.23 \mathrm{~b} \\
17.58\end{array}$ & $\begin{array}{l}4.52 \\
5.71 \\
6.59 \mathrm{~b} \\
15.35\end{array}$ & $\begin{array}{l}\mathrm{ns} \\
\mathrm{ns} \\
<0.001 \\
\mathrm{~ns}\end{array}$ \\
\hline $\begin{array}{l}\text { N Yield } \\
(\mathrm{kg} \mathrm{N} / \mathrm{ha})\end{array}$ & $\begin{array}{l}\text { Moderate permanent grassland } \\
\text { Intensive permanent grassland } \\
\text { Ley grass } \\
\text { Maize }\end{array}$ & $\begin{array}{l}96.8 \mathrm{ab} \\
118.9 \\
72.3 \mathrm{a} \\
125.8 \mathrm{ab}\end{array}$ & $\begin{array}{l}121.5 \mathrm{a} \\
126.6 \\
191.0 \mathrm{~b} \\
159.4 \mathrm{a}\end{array}$ & $\begin{array}{l}71.4 \mathrm{~b} \\
140.9 \\
165.3 \mathrm{~b} \\
84.0 \mathrm{~b}\end{array}$ & $\begin{array}{l}<0.01 \\
\mathrm{~ns} \\
<0.001 \\
<0.001\end{array}$ \\
\hline $\begin{array}{l}\text { Energy content } \\
\text { (MJ NEL/kg } \\
\text { DM) }\end{array}$ & $\begin{array}{l}\text { Moderate permanent grassland } \\
\text { Intensive permanent grassland } \\
\text { Ley grass } \\
\text { Maize }\end{array}$ & $\begin{array}{l}5.93 \mathrm{a} \\
6.15 \mathrm{a} \\
6.01 \\
5.85\end{array}$ & $\begin{array}{l}5.98 \mathrm{a} \\
5.87 \mathrm{~b} \\
6.25 \\
6.10\end{array}$ & $\begin{array}{l}4.44 \mathrm{~b} \\
6.01 \mathrm{ab} \\
6.11 \\
6.05\end{array}$ & $\begin{array}{l}<0.001 \\
<0.05 \\
\text { ns } \\
\text { ns }\end{array}$ \\
\hline $\begin{array}{l}\text { Crude protein } \\
\text { (g/kg DM) }\end{array}$ & $\begin{array}{l}\text { Moderate permanent grassland } \\
\text { Intensive permanent grassland } \\
\text { Ley grass } \\
\text { Maize }\end{array}$ & $\begin{array}{l}150.7 \mathrm{a} \\
150.9 \\
134.1 \mathrm{a} \\
69.0 \mathrm{a}\end{array}$ & $\begin{array}{l}149.1 \mathrm{a} \\
150.0 \\
176.8 \mathrm{~b} \\
62.9 \mathrm{a}\end{array}$ & $\begin{array}{l}103.2 \mathrm{~b} \\
162.5 \\
165.3 \mathrm{~b} \\
36.0 \mathrm{~b}\end{array}$ & $\begin{array}{l}<0.001 \\
\mathrm{~ns} \\
<0.001 \\
<0.001\end{array}$ \\
\hline $\begin{array}{l}\text { Nitrogen use } \\
\text { efficiency } \\
\text { (\%) }\end{array}$ & $\begin{array}{l}\text { Moderate permanent grassland } \\
\text { Intensive permanent grassland } \\
\text { Ley grass } \\
\text { Maize }\end{array}$ & $\begin{array}{l}121 \mathrm{ab} \\
50 \\
21 \mathrm{a} \\
79 \mathrm{a}\end{array}$ & $\begin{array}{l}152 \mathrm{a} \\
53 \\
56 \mathrm{~b} \\
100 \mathrm{~b}\end{array}$ & $\begin{array}{l}87 \mathrm{~b} \\
59 \\
49 \mathrm{~b} \\
52 \mathrm{ab}\end{array}$ & $\begin{array}{l}<0.01 \\
\mathrm{~ns} \\
<0.001 \\
<0.001\end{array}$ \\
\hline $\begin{array}{l}\text { Soil mineral N } \\
(\mathrm{kgN} / \mathrm{ha})\end{array}$ & $\begin{array}{l}\text { Moderate permanent grassland } \\
\text { Intensive permanent grassland } \\
\text { Ley grass } \\
\text { Maize }\end{array}$ & $\begin{array}{l}11.0 \mathrm{a} \\
12.8 \\
13.8 \mathrm{a} \\
51.1\end{array}$ & $\begin{array}{l}13.1 \mathrm{ab} \\
18.6 \\
22.6 \mathrm{ab} \\
49.5\end{array}$ & $\begin{array}{l}19.4 \mathrm{~b} \\
23.2 \\
36.5 \mathrm{~b} \\
25.5\end{array}$ & $\begin{array}{l}<0.05 \\
\mathrm{~ns} \\
<0.001 \\
\mathrm{~ns}\end{array}$ \\
\hline
\end{tabular}

Tab. 4.5: Climatic parameters of all sites in all observation years. AMT = annual mean temperature, vegT $=$ temperature during vegetation period.

\begin{tabular}{cccccc}
\hline Year & Site & $\begin{array}{c}\text { AMT } \\
\left({ }^{\circ} \mathbf{C}\right)\end{array}$ & $\begin{array}{c}\text { vegT } \\
\left({ }^{\circ} \mathbf{C}\right)\end{array}$ & $\begin{array}{c}\text { Annual Precipitation } \\
(\mathbf{m m})\end{array}$ & $\begin{array}{c}\text { Precipitation during } \\
\text { Vegetation Period (mm) }\end{array}$ \\
\hline \multirow{6}{*}{2012} & DH & 9.7 & 13.7 & 620.4 & 366.8 \\
& HK & 9.1 & 13.3 & 707.7 & 404.7 \\
& UE & 9.2 & 13.5 & 584.4 & 359.1 \\
& FL & 9.3 & 14.3 & 617.4 & 384.9 \\
& OS & 9.5 & 14.1 & 591.6 & 358.1 \\
& DH & 9.2 & 14.0 & 577.2 & 352.5 \\
& HK & 8.8 & 13.7 & 654.7 & 402.7 \\
& UE & 8.9 & 13.9 & 743.2 & 531.7 \\
& FL & 8.9 & 14.5 & 671.6 & 433.9 \\
& OS & 9.2 & 14.3 & 543.9 & 347.5 \\
& & & & & 508.0 \\
& DH & 10.9 & 14.9 & 695.9 & 413.2 \\
& HK & 10.5 & 14.6 & 626.9 & 440.5 \\
& UE & 10.5 & 14.7 & 611.6 & 465.3 \\
\hline
\end{tabular}


The $\mathrm{N}$ yields of moderate permanent grassland, ley grass and maize differed significantly among the three experimental years (Tab. 4.4). However, these differences did not correlate with precipitation and temperature of respective years. The smaller $\mathrm{N}$ yields of ley grass in the first year compared to the two following years (Tab. 4.4) are probably a result of the time that the ley grass sward needed to establish after sowing in spring of the first year.

For maize, a strong growth of weeds in 2014 that could not be fully controlled by herbicides and weeding (see section 4.3.2) might be the reason why the $\mathrm{N}$ yields and crude protein concentrations were low in this year (Tab. 4.4).

\subsubsection{The influence of management intensification on yield and forage quality}

In our experiments the intensification of forage production on extensively managed permanent grasslands on sandy soils did not always led to yields and forage qualities that we had intended and expected. The common knowledge is that fertilization rapidly increases productivity in semi-natural grasslands (Suding et al., 2005; Clark et al., 2007; Chalcraft et al., 2008). Furthermore, a renovation of the grassland sward normally tends to improve the forage crop production, at least in the first years (e.g. Søegaard et al., 2004). However, in our experiments the mean dry matter yields of all grassland treatments (PGM, PGI and Ley) were relatively low (Tab. 4.6). Mean dry matter yields ranged from $4.8 \mathrm{t} \mathrm{DM} /$ ha in moderate permanent grassland to $5.8 \mathrm{t} \mathrm{DM} /$ ha in ley grass. Intensification from moderate to intensive permanent grassland did not significantly increase dry matter yields (Tab. 4.6). Under favorable soil conditions, intensive grassland and ley grass can produce yields up to 12 and $14 \mathrm{t} \mathrm{DM/ha,} \mathrm{respectively} \mathrm{(KTBL,} \mathrm{2009).} \mathrm{Even} \mathrm{under} \mathrm{poor}$ soil conditions, ley grass produced up to $10 \mathrm{t} \mathrm{DM} / \mathrm{ha}$ when more than $300 \mathrm{~kg} \mathrm{~N} / \mathrm{ha} / \mathrm{yr}$ were applied (Thomas et al., 1991).

We assume that the low yields of moderate permanent grassland, intensive permanent grassland and ley grass were a result of complex interactions between site and soil conditions, former management, sward composition and new fertilization and cutting regime (e.g. Käding et al., 2005; Abassi et al., 2007).

The mean energy content and crude protein concentrations in moderate and intensive permanent grassland and ley grass, however, were in a range that can be regarded as sufficient for at least some production parts of most livestock feeding systems (Tab. 4.6; compare: KTBL, 2009). 
It has been found that yield and forage quality of grasslands are often affected differently when the production intensity is changed and increasing yields in grassland can go along with decreasing forage qualities (e.g. Shi et al., 2013). In our study, increasing the management intensity from moderate to intensive permanent grassland had a positive effect on mean $\mathrm{N}$ yields, energy content and mean crude protein concentration of the forage but not on dry matter yield (Tab. 4.6, Fig. 4.2). A further step in management intensity from intensive permanent grassland to ley grass, which included breaking up the sward, however, showed no positive effects on forage quality (Tab. 4.6, Fig. 4.2). With the transition from intensive permanent grassland to ley grass an established plant community that was adapted to site conditions and former management was destroyed. Replacing an adapted and extensively managed sward by a newly sown ley grass mixture did not increase forage quality in the first three years under unfavorable soil conditions. If we consider only forage quality we might conclude that intensive permanent grassland seems to be an option when production of former extensive grassland is supposed to be increased on sandy soils. The intensive permanent grassland also showed a high stability in yield and forage quality parameters during the experimental years and among sites (Tab. 4.4). We assume that the increased nitrogen application compared to the moderate permanent grassland buffered possible site or year effects (Diepholder and Jakob, 2002). The mean dry matter yields of maize in our experiments (15.51 t DM/ha) were good and as expected in practice (Tab. 4.6, compare: Kayser et al., 2011). The mean energy content of maize (6.01 MJ NEL/kg DM), however, was rather low (Tab. 4.6) (compare: KTBL, 2009). The mean crude protein concentration of maize $(55.1 \mathrm{~g} / \mathrm{kg} \mathrm{DM})$ and especially the crude protein concentration in 2014 (36 g/kg DM), were also very low (Tab. 4.4). Normally crude protein concentration in maize is about $90 \mathrm{~g} / \mathrm{kg} \mathrm{DM}$ (KTBL, 2009). In 2012 and 2013 we assume that the unfavorable soil conditions led to an inhibited $\mathrm{N}$ uptake of the maize plants which resulted in reduced energy and protein concentrations while yields were sufficient. We applied $\mathrm{N}$ to maize in two doses, the first at the time of planting and the second around mid-June to July. It might be that the second fertilization at the beginning of July has been too late to get into full effect (Landwirtschaftskammer NRW, Recommendations silage maize fertilization). In 2014, herbicides were applied three weeks later than in the two other observation years and additional weeding by hand was necessary - maize plants had suffered from competition with weeds at that time to some degree. The dominant weed in the maize plots on all sites was the white goosefoot (Chenopodium album), a fast growing arable weed which can reach heights of up to 150 
$\mathrm{cm}$. We assume that some of the applied nitrogen had been taken up by this weed and would return to the soil only later after killing. The reduced crude protein concentration of maize and the reduced soil mineral $\mathrm{N}$ under the maize plots in 2014 (Tab. 4.4) also point to less available nitrogen in the soil compared to the other years (compare Wachendorf et al., 2006).

\subsubsection{The influence of management intensification on other ecosystem services}

The yield stability of grassland systems has been found to increase with increasing plant diversity, ensuring adequate yields also in years with unfavorable weather conditions (Deak et al. 2009; Silvertown et al., 2006; Tilman et al., 2006). However, a higher plant diversity in grassland ecosystems does not necessarily result in a positive effect on nutrient retention (Mulder et al., 2002; Niklaus et al., 2006; Harrison et al., 2007; Weigelt et al., 2005), water use efficiency (Caldeira et al., 2001; van Peer et al., 2004) or on economic parameters. Many studies conducted at different scales have shown that nutrient enrichment causes a rapid decline in plant diversity (Tilman, 1987; Berendse and Elberse, 1990; Wedin and Tilman, 1996; Gough et al., 2000, Zechmeister et al., 2003; Stevens et al., 2004; Crawley et al., 2005; Niu et al., 2014: Korevaar and Geerts, 2015). The moderate and intensive permanent grassland in our experiment could not be assigned to "species-rich grassland" concerning existing Agri-environment measures in the respective federal states. Nevertheless, both treatments showed an average of 15 species per $15 \mathrm{~m}^{2}$. It seems that the larger input of $\mathrm{N}, \mathrm{P}$ and $\mathrm{K}$ in the intensive grassland and the higher cutting frequency of four instead of two cuts per year did not lead to a loss of plant diversity compared to the moderate grassland (Tab. 4.6). As we found no $\mathrm{N}$ sensitive plant species on our sites we assume that under the given circumstances a moderate intensification does not pose the risk of an immediate decrease in plant species.

As expected, the mean nitrogen use efficiency (NUE) decreased with increasing amount of $\mathrm{N}$ application (increasing intensity level) (Tab. 4.6). The nitrogen use efficiency of moderate permanent grassland was above $100 \%$ in all years (Tab. 4.4) and can already be a sign for a non-balanced nitrogen supply. If the removal of nitrogen from the system is continued over time there is the risk of soil mining and depletion (Berentrup and Pallier, 2010).

The mean NUE of intensive permanent grassland (56\%) and especially ley grass (42\%) were rather low. Oenema et al. (2015) found an average NUE of grasslands on intensively 
managed Dutch dairy farms of $61 \%$. Low NUE is an indicator that $\mathrm{N}$ is lost from the system, either through leaching or gaseous losses. As we only used mineral fertilizer in our experiment, gaseous $\mathrm{N}$ losses are negligible, but $\mathrm{N}$ losses through leaching might have occurred. We investigated the amount of soil mineral $\mathrm{N}$ in autumn as an indicator for the risk of $\mathrm{N}$ leaching (Homm, 1994; Wachendorf et al., 2006). We found that residual soil mineral $\mathrm{N}(0-30 \mathrm{~cm})$ in all grassland treatments increased from year to year which indicates more available $\mathrm{N}$ that had not been taken up by plants and/or had mineralized at the time (Tab. 4.4). However, the overall amount of soil mineral $\mathrm{N}$ in top soil (0-30 $\mathrm{cm}$ ) was quite small - although almost $40 \mathrm{~kg} / \mathrm{ha}$ for ley grass in $30 \mathrm{~cm}$ point at a potential risk for $\mathrm{N}$ translocation and even leaching (Tab. 4.6). On average over the years the soil mineral $\mathrm{N}$ under intensive permanent grassland was not higher than under moderate permanent grassland (Tab. 4.6); and on intensive permanent grassland not higher than on ley grass - however, soil mineral $\mathrm{N}(0-30 \mathrm{~cm})$ under ley grass was significantly larger than that of the other treatments in the last experimental year 2014 (data not shown). Kayser et al. (2015) found residual mineral $\mathrm{N}$ in permanent grassland fertilized up to 320 $\mathrm{kg} \mathrm{N} / \mathrm{ha}$ with mineral $\mathrm{N}$ or slurry on average below $50 \mathrm{~kg} \mathrm{~N} / \mathrm{ha}$ and related $\mathrm{N}$ (nitrate) leaching less than $15 \mathrm{~kg} / \mathrm{ha}$ per year. Ley grass following a break-up can result in much larger soil mineral N and potential leaching (Reheul, 2007; Pötsch et al. 2013).

Maize showed a relatively high NUE in all years (Tab. 4.4) and a mean NUE of $77 \%$ (Tab. 4.6). However, the average amount of soil mineral $\mathrm{N}(0-30 \mathrm{~cm})$ of $42.0 \mathrm{~kg} \mathrm{~N} / \mathrm{ha}$ after maize was significantly higher than the one under the permanent grassland treatments 14.5 and $20.7 \mathrm{~kg} \mathrm{~N} / \mathrm{ha}$ respectively for PGM and PGI. Soil mineral N (0-30 $\mathrm{cm}$ ) in autumn after maize decreased from $51.1 \mathrm{~kg} \mathrm{~N} / \mathrm{ha}$ in 2012 to $25.5 \mathrm{~kg} \mathrm{~N} / \mathrm{ha}$ in 2014 (Tab. 4.6). The large residual $\mathrm{N}$ in the first year after maize can be seen as a result of the increased $\mathrm{N}$ mineralization rate after the breaking up of the grassland sward (Hatch et al., 2003) and indicate leaching of $\mathrm{N}$ or translocation to deeper soil layers (e.g. Adams and Jan, 1999; Shepherd et al., 2001 and Springob, 2004). 
Tab. 4.6: Differences in yield, forage quality and other ecosystem service parameters among treatments. $\mathrm{Sd}=$ Standard deviation. Letters indicating significant differences among treatments (rows). * treatment was not included statistical analysis.

\begin{tabular}{|c|c|c|c|c|}
\hline Parameter & Treatment (Intensity Level) & Mean & Sd & P value \\
\hline $\begin{array}{l}\text { Dry matter yield } \\
(\mathrm{t} / \mathrm{ha})\end{array}$ & $\begin{array}{l}\text { Moderate permanent } \\
\text { grassland Intensive } \\
\text { permanent grassland } \\
\text { Ley grass } \\
\text { Maize* }\end{array}$ & $\begin{array}{l}4.79 \mathrm{a} \\
5.53 \mathrm{ab} \\
5.82 \mathrm{~b} \\
15.51\end{array}$ & $\begin{array}{l}1.64 \\
1.41 \\
2.13 \\
6.38\end{array}$ & $\mathrm{p}<0.001$ \\
\hline $\begin{array}{l}\text { N Yield } \\
(\mathrm{kg} \mathrm{N} / \mathrm{ha})\end{array}$ & $\begin{array}{l}\text { Moderate permanent } \\
\text { grassland Intensive } \\
\text { permanent grassland } \\
\text { Ley grass } \\
\text { Maize }\end{array}$ & $\begin{array}{r}96.6 \mathrm{a} \\
128.8 \mathrm{~b} \\
142.9 \mathrm{~b} \\
122.8 \mathrm{ab}\end{array}$ & $\begin{array}{l}42.8 \\
35.0 \\
60.8 \\
58.6\end{array}$ & $\mathrm{p}<0.001$ \\
\hline $\begin{array}{l}\text { Energy content } \\
\text { (MJ NEL/kg DM) }\end{array}$ & $\begin{array}{l}\text { Moderate permanent } \\
\text { grassland Intensive } \\
\text { permanent grassland } \\
\text { Ley grass } \\
\text { Maize }\end{array}$ & $\begin{array}{l}5.45 \mathrm{a} \\
6.01 \mathrm{~b} \\
6.15 \mathrm{~b} \\
6.01 \mathrm{~b}\end{array}$ & $\begin{array}{l}0.82 \\
0.27 \\
0.37 \\
0.43\end{array}$ & $\mathrm{p}<0.001$ \\
\hline $\begin{array}{l}\mathrm{CP} \\
(\mathrm{g} / \mathrm{kg} \mathrm{DM})\end{array}$ & $\begin{array}{l}\text { Moderate permanent } \\
\text { grassland Intensive } \\
\text { permanent grassland } \\
\text { Ley grass } \\
\text { Maize }\end{array}$ & $\begin{array}{l}134.3 \mathrm{a} \\
154.5 \mathrm{~b} \\
158.7 \mathrm{~b} \\
55.1 \mathrm{c}\end{array}$ & $\begin{array}{l}31.0 \\
20.0 \\
30.9 \\
20.5\end{array}$ & $\mathrm{p}<0.001$ \\
\hline $\begin{array}{l}\text { Plant species richness } \\
\text { (n) }\end{array}$ & $\begin{array}{l}\text { Moderate permanent } \\
\text { grassland Intensive } \\
\text { permanent grassland } \\
\text { Ley grass } \\
\text { Maize* }\end{array}$ & $\begin{array}{l}14.9 \mathrm{a} \\
14.7 \mathrm{a} \\
10.5 \mathrm{~b} \\
13.4\end{array}$ & $\begin{array}{l}3.0 \\
1.9 \\
2.4 \\
1.7\end{array}$ & $\mathrm{p}<0.001$ \\
\hline $\begin{array}{l}\text { Nitrogen use efficiency } \\
(\%)\end{array}$ & $\begin{array}{l}\text { Moderate permanent } \\
\text { grassland Intensive } \\
\text { permanent grassland } \\
\text { Ley grass } \\
\text { Maize }\end{array}$ & $\begin{array}{r}121 \mathrm{a} \\
54 \mathrm{~b} \\
42 \mathrm{c} \\
77 \mathrm{~d}\end{array}$ & $\begin{array}{l}54 \\
15 \\
18 \\
37\end{array}$ & $\mathrm{p}<0.001$ \\
\hline $\begin{array}{l}\text { Soil mineral N } \\
(\mathrm{kgN} / \mathrm{ha})\end{array}$ & $\begin{array}{l}\text { Moderate permanent } \\
\text { grassland Intensive } \\
\text { permanent grassland } \\
\text { Ley grass } \\
\text { Maize }\end{array}$ & $\begin{array}{l}14.5 \mathrm{a} \\
20.7 \mathrm{ab} \\
24.3 \mathrm{bc} \\
42.0 \mathrm{c}\end{array}$ & $\begin{array}{l}8.5 \\
22.2 \\
17.8 \\
42.9\end{array}$ & $\mathrm{p}<0.001$ \\
\hline
\end{tabular}




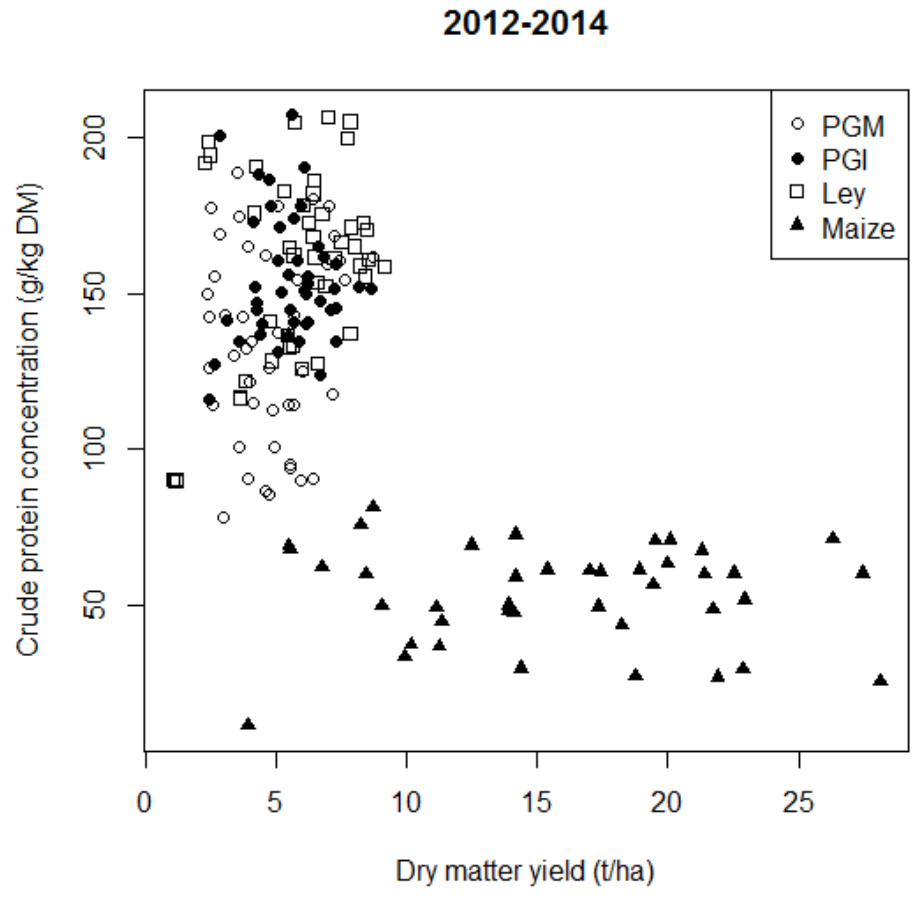

Fig. 4.1: Relation of mean crude protein concentration and dry matter yields of all treatments in 2012-2014. PGM = moderate permanent grassland, PGI = intensive permanent grassland, Ley $=$ Ley grass, Maize $=$ Cultivation of maize .

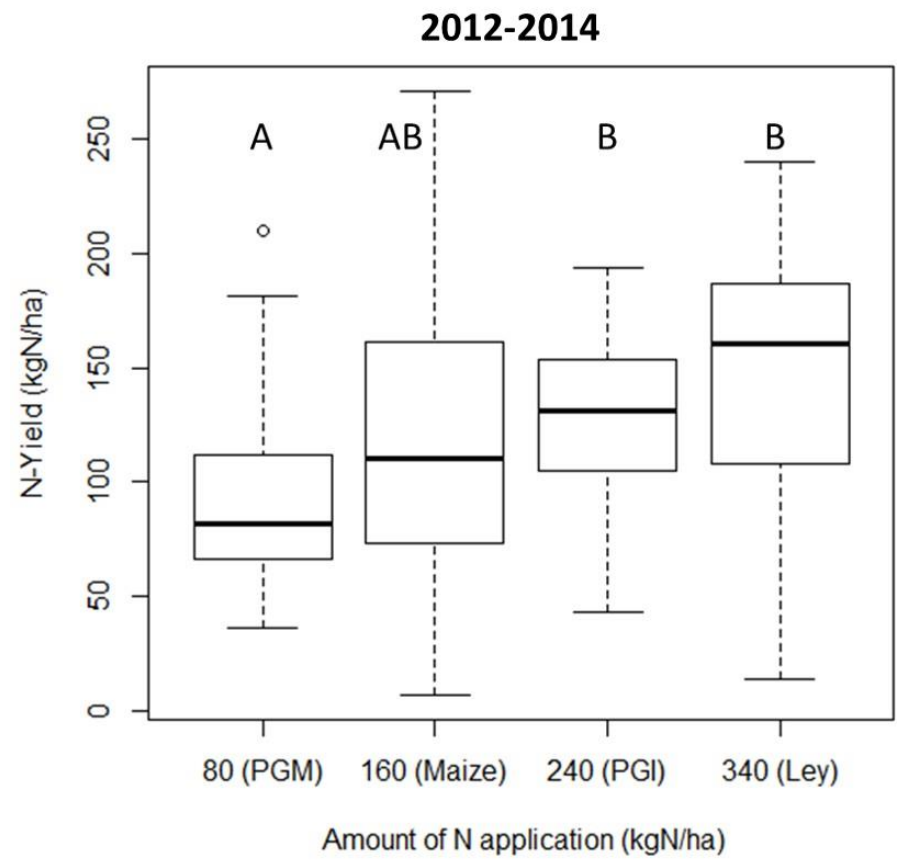

Fig. 4.2: $\mathrm{N}$ yield in relation to the amount of annual $\mathrm{N}$ application on all treatments in 2012-2014. PGM = moderate permanent grassland, PGI = intensive permanent grassland Ley $=$ Ley grass, Maize $=$ Cultivation of maize. Letters A and B indicate significant differences $(p<0.01)$ among treatments. 


\subsection{Conclusion}

A moderate intensification of formerly extensive grassland by slightly increasing the $\mathrm{N}$ input and increasing the cutting frequency with the aim of more stable yields and good forage quality does not necessarily have to result in a loss of species number or increased risk of $\mathrm{N}$ loss and can be an option on unfavorable soils.

We conclude that an adapted intensive management of permanent grassland can avoid a loss of ecosystem services (Conijn et al. 2002) and simultaneously deliver forage of adequate quality that can, in contrast to extensive grassland forage (Spatz, 1994; Stoll et al., 2001), be used in profitable cattle production systems.

\section{6 Acknowledgments}

This project (Nachhaltiges Landmanagement im Norddeutschen Tiefland, FKZ 033L029) was supported by the German Federal Ministry of Education and Research (BMBF). We would like to take this opportunity to thank Uwe Vehlow, Barbara Hohlmann and colleagues from the University of Göttingen for the analysis of forage and soil samples.

\subsection{Literature}

Abassi, M.K., Kazmi, M., and ul Hussan, F. (2007) Nitrogen Use Efficiency and Herbage Production of an Established Grass Sward in Relation to Moisture and Nitrogen Fertilization. Journal of Plant Nutrition 28, 1693-1708.

Adams, W.A., and Jan, M.T. (2006). Utilization of nitrogen accumulated by a clover containing ley following cultivation. Soil Use and Management 15, 247-253.

Allan, E., Bossdorf, O., Dormann, C.F., Prati, D., Gossner, M.M., Tscharntke, T., Blüthgen, N., Bellach, M., Birkhofer, K., Boch, S., et al. (2014) Interannual variation in land-use intensity enhances grassland multidiversity. Proceedings of the National Academy of Sciences (PNAS) 111, 308-313.

Allan, E., Manning, P., Alt, F., Binkenstein, J., Blaser, S., Blüthgen, N., Böhm, S., Grassein, F., Hölzel, N., Klaus, V.H., et al. (2015) Land use intensification alters ecosystem multifunctionality via loss of biodiversity and changes to functional composition. Ecology Letters 18, 834-843.

Buxton, D.R. and Casler, M.D. (1993) Environmental and genetic effects on cell-wall composition and digestibility. In: Jung H.G., Buxton D.R., Hatfield R. D. and Ralph J. (eds). Forage cell wall structure and digestibility, pp. 685-714. Madison, WI: ASA, CSSA \& SSSA. 
Buxton, D.R. and Fales, S.L. (1994) Plant environment and quality. In: Fahay G.C. Jr., Collins M., Mertens, D.R. and Moser, L.E. (eds). Forage quality, evaluation and utilization, pp. 155-199. Lincoln, NE: ASA, CSSA \& SSSA.

Brentrup, F. and Palliere, C. (2010) Nitrogen use efficiency as an agro - environmental indicator. OECD workshop: Agri - environmental indicators: lessons learned and future directions, 23 - 26 March 2010, Leysin, Switzerland.

Caldeira, M.C., Ryel, R.J. and Lawton, J.H. and Pereira, J.S. (2001) Mechanisms of positive biodiversity-production relation- ships: insights provided by $\mathrm{d} 13 \mathrm{C}$ analysis in experimental Mediterranean grassland plots. Ecology Letters 4, 439-443.

Conijn, J.G., Velthof G.L and Taube F. (2002) Grassland resowing and grass-arable crop rotations. International workshop on agricultural and environmental issues. EGF Working Group on grassland resowing and grass-arable rotations, Report No. 1.

Deak, A., Hall, M.H. and Sanderson, M.A. (2009) Grazing schedule effect on forage production and nutritive value of diverse forage mixtures. Agronomy Journal 101, 408414.

Harrison, K.A., Bol, R. and Bardgett, R.D. (2007) Preferences for different nitrogen forms by coexisting plant species and soil microbes. Ecology 88, 989-999.

Hatch, D.J., Hopkins, A. and Velthof, G.L. (2003) Nitrogen and phosphorus cycling in grass-to-grass resowing and grass-arable rotations. In: EGF Working Group 'Grassland Resowing and Grass-arable Rotations' Report 2, 5-23.

Käding, H., Kaiser, T., and Werner, A. (2005) Model for calculating grassland yields and forage quality in North-East Germany on the basis of site and management characteristics. Archives of Agronomy and Soil Science 51, 417-431.

Kaiser, T., Käding, H., Kiesel, J., Müller, L., Hierold, W., and Behrendt, A. (2005) The derivation of grassland vegetation types on the basis of site and land use characteristics. Archives of Agronomy and Soil Science 51, 405-416.

Kayser, M., Benke, M., Isselstein, J. (2011) Little fertilizer response but high N loss risk of maize on a productive organic-sandy soil. Agronomy for Sustainable Development 31, 709 .

Kayser, M., Breitsameter, L., Benke, M., Isselstein, J. (2015) Nitrate leaching is not controlled by the slurry application technique in productive grassland on organic-sandy soil. Agronomy for Sustainable Development 35, 213-223.

Korevaar, H. and Geerts, R. (2015) Long-term effects of nutrients on productivity and species-richness of grasslands: the Ossekampen Grassland Experiment. Aspects of Applied Biology 128, 253-256.

Müller, H. (1953) Wiesentypen und Futterertrag. Grünland 2, 41 - 42. 
Mulder, C.P.H., Jumpponen, A., Högberg and Huss-Danell, P. K. (2002) How plant diversity and legumes affect nitrogen dynamics in experimental grassland communities. Oecologia 133, 412-421.

Neuwirth, C., and Hofer, B. (2013) Spatial sensitivity of grassland yields to weather variations in Austria and its implications for the future. Applied Geography 45, 332-341.

Niklaus, P., Wardle, D. and Tate, K. (2006) Effects of plant species diversity and composition on nitrogen cycling and the trace gas balance of soils. Plant and Soil 282, 83-98.

Niu, K., Choler, P., de Bello, F., Mirotchnick, N., Du, G., and Sun, S. (2014) Fertilization decreases species diversity but increases functional diversity: A three-year experiment in a Tibetan alpine meadow. Agriculture, Ecosystem and Environment 182, $106-112$.

Oenema, J., Hilhorst, G.J., and Ittersum, M.K. (2015) Improving grassland management on commercial pilot dairy farms: the role of intensive coaching. Grassland Science in Europe 20, 466-468.

Pammer, G., and Ranninger, R. (1928) Der rationelle Getreidebau. Vienna: Springer Vienna.

Pötsch, E.M., Klopf, K., Graiss, W.,Resch, R. and Krautzer, B. (2013) Impact of different fertilization intensity on nutrient leaching in ley-based farming systems. Grassland Science in Europe 18, 111-113.

Reheul, D., Devligher, A., Bommelé, L.,Carlier, L. (2007) The comparison between temporary and permanent grassland. Grassland Science in Europe 12, 1-13.

Silvertown, J., Poulton, P., Johnston, E., Edwards, G., Heard, M. and Biss, P.M. (2006) The park grass experiment 1856-2006: its contribution to ecology. Journal of Ecology 94, 801-814.

Soegaard, K., Gierus, M., Hopkins, A. and Bommelé, L. (2007) Effects of grassland renovation on crop and animal performance. In: Grassland resowing and grass-arable crop rotations. Third and fourth workshop of the EGF working group. Report 148. Wageningen Plant Research International. 95 - 105.

Shepherd, M. A., Hatch, D. J., Jarvis, S. C. and Bhogal, A. (2001) Nitrage leaching from reseeded pasture. Soil Use and Management 17, 97-105.

Shi, Y., Ma, Y., Ma, W., Liang, C., Zhao, X., Fang, J., He, J. (2013) Large scale patterns of forage yield and quality across Chinese grasslands. Chinese Science Bulletin 58, 1187-1199.

Spatz, G. (1994) Freiflächenpflege. Ulmer Verlag. Stuttgart.

Springob, G. (2004) C and N losses in sandy soils of NW Germany after conversion of grassland. In: Lüscher, A., Jeangros, B.,Kessler, W., Huguenin, O., Kobsiger, M., 
Millar, N., and Suter, D. (eds). Land Use Systems in Grassland Dominated Regions. Grassland Science in Europe 9, 529-531.

Stoll, W., Arrigo, Y., Chassot, A., Daccord, R., Kessler, J. and Wyss, U. (2001) Bedeutung Artenreicher Wiesen als Futter. Schriftenreihe der FAL 39, 108-114.

Taube, F. and Conijn, J. (2007) Grassland renovation in Northwest Europe: current practices and main agronomic and environmental questions. In: Grassland resowing and grass-arable crop rotations. Third and fourth workshop of the EGF working group. Report 148. Wageningen Plant Research International. 35- 38.

Thébault, A., Mariotte, P., Lortie, C.J., and MacDougall, A.S. (2014) Land management trumps the effects of climate change and elevated $\mathrm{CO}_{2}$ on grassland functioning. Journal of Ecology 102, 896-904.

Thomas C., Reeve A. \& Fisher G.E.J. (1991) Milk from Grass, 2nd Edition. British Grassland Society.

Tilman, D. (2001) Forecasting Agriculturally Driven Global Environmental Change. Science 292, 281-284.

van Peer L, Nijs, I., Reheul, D. and de Cauwer, B. (2004) Species richness and susceptibility to heat and drought extremes in synthesized grassland ecosystems: compositional vs physiological effects. Functional Ecology 18, 769-778.

Wachendorf, M., Buchter, M., Volkers, K.C., Bobe, J., Rave, G., Loges, R., and Taube, F. (2006) Performance and environmental effects of forage production on sandy soils. $\mathrm{V}$. Impact of grass understory, slurry application and mineral $\mathrm{N}$ fertilizer on nitrate leaching under maize for silage. Grass Forage Science 61, 243-252.

Wachendorf, M. and Taube, F. (2002) Management impacts on nitrogen fluxes and nitrogen losses in grassland systems - Results from an integrated project. Grassland Science in Europe 7, 746-747.

Zechmeister, H.G., Schmitzberger, I., Steurer, B., Peterseil, J., Wrbka, T. (2003) The influence of land-use practices and economics on plant species richness in meadows. Biological Conservation 114, 165-177. 


\title{
CHAPTER 5
}

\author{
Synthesis
}




\section{Synthesis}

Grassland management for forage production is a complex matter as grasslands are very diverse with a range of different management intensities that vary from very extensive to very intensive. The livestock and related forage production system determines the management intensity of grasslands. In Germany, the prevalent forage production differs on a regional scale as well. On livestock producing farms grassland production is often combined with the cultivation of leys and silage maize. The on-going intensification of livestock and related forage production systems leads to more and stronger trade-offs between productivity and ecosystem service functions. An increased cultivation of high energy crops on arable land at the expense of permanent grasslands means that important ecosystem services related to permanent grassland like biodiversity, nutrient retention, water purification and also $\mathrm{C}$ sequestration are reduced and the sustainability of the forage production systems decreases.

As discussed in CHAPTER 1, for a successful integration of sustainable production systems into the agricultural praxis the farmers needs to be actively involved. Regional agri-environment measures that are adapted to regional conservation goals can help to preserve sustainable grassland farming in northern Germany. Most farmers do not have a general negative attitude towards nature conservation. However, the number of famers that actually do use AEM is comparably small. Different farmers have different reasons for not taking part in these measures. Farmers should be addressed individually by advisory services concerning AEM. A better communication among politicians, farmers and conservationists is a prerequisite for a better implementation of AEM into the agricultural praxis in Germany. Farmers play a crucial role in nature conservation and there is a need to place "farmland biodiversity in the hands and minds of farmers".

Due to the multifunctionality of permanent grassland, pasture-based systems in livestock production are regarded as more friendly for the environment, as promoting animalwelfare, and are thought to yield healthier products compared to non-grazing systems. To verify these sustainable feeding regimes simple and robust indicators are very useful. In CHAPTER 2 the ${ }^{13} \mathrm{C}$ isotopic signatures in cattle tail switch hair was used to retrospectively validate cattle production systems that are supposed to be based on forage from pasture and not maize. This method can be a valuable tool to verify a reported feeding system that helps to preserve ecosystem services. 
Sustainable forage production on permanent grassland includes both, the provisioning of ecological functions but also the preservation of the production function. A lot of ecosystem services that are provided by permanent grasslands are based on an adequate management. An adequate management that delivers forage of adequate quality and simultaneously preserves other ecosystem services depends very much on site conditions. CHAPTER 3 describes that under certain environmental conditions, an adapted intensification of formerly more extensively managed grassland can be a good compromise to achieve economic and ecological goals. 


\title{
CHAPTER 6
}

\author{
Summary
}




\subsection{Summary}

Grassland is seen to fulfil a range of functions: Grasslands deliver biomass for livestock and energy production and provide several ecosystem services like biodiversity and wildlife protection, carbon sequestration, water purification, nutrient retention and also social benefits like recreation. This multifunctionality, however, strongly depends on the intensity of management and on environmental conditions. Grassland farming plays an important role among the agricultural production systems in Germany and grasslands are mainly used for cattle production. In northern Germany, the proportion of grassland of the total agricultural land ranges from 20 to over $30 \%$. There is an on-going trend towards an intensification of land-use and increasing milk yields which require higher energy contents in forage. Grassland farmers have to follow this trend if their enterprise is to remain profitable. This results in an intensification of grassland management - usually an increased $\mathrm{N}$ input and more cuts - with the extension of the cultivation of ley grass or the cultivation of the high energy crop maize for cattle fodder. As it is mainly extensively or moderately managed grassland that provides many ecosystems services, the intensification of grassland management can weaken its multifunctionality.

The first aim of this dissertation was to analyzed farmer's attitude and behavior concerning voluntary Agri-environment measures (AEM). These measures tend to promote a more extensive grassland management by providing governmental support payments to farmers. A standardized questionnaire was developed to be answered faceto-face by 82 grassland farmers on a west to east gradient in northern Germany. The selection of farms was based on census data to achieve a representative picture of the area. Questions were asked concerning personal data, farm management and business management as well as on general agricultural and nature protection issues. The results indicate that the majority of grassland farmers is generally interested in nature conservation and believes it to be of concern for every farmer. In contrast, only a minority of the respondents is using the existing AEM to the full extend on their own farm. By applying the concept of farming styles, we classified farmers into four groups, namely Traditionalist, Idealist, Modernist, and Yield Optimizer. These farming styles groups differ in farm and management parameters, general attitudes towards agricultural issues, farming objectives and economic success. We found that in our survey the farming styles groups differ in their attitude towards nature conservation. However, they do not differ in the adoption of AEM and have different reasons for not taking part. We state that for a better implementation of AEM into agricultural practice a better communication, which 
is adapted to the different ways that farmers manage their farm and think and feel, is needed. Consequently, AEM need to be revised as well.

The second aim was to find a simple method that can be used in practice to retrospectively check on mean maize contents in diet of different cattle production systems over a longer period without frequently and costly surveys on the farms. Sections from cattle hair serve as an isotopic archive - they contain information on diet from different time periods. We tested the reliability of ${ }^{13} \mathrm{C}$ signatures $\left(\delta^{13} \mathrm{C}\right)$ in cattle tail switch hair to retrospectively trace back the annual mean dietary proportion of maize of different production systems without having to sample and analyze the feed. Furthermore, we investigated if differences in dietary proportion of maize during summer and winter feeding can be detected by sampling hair only once a year. We sampled hair and obtained information on management and annual mean composition of diets on 23 cattle farms in northern Germany. Farms differed in dietary proportions of maize, grass and other concentrates as well as in grazing regime (year-round grazing, summer grazing, no grazing). We found that the mean $\delta^{13} \mathrm{C}$ of two hair sections that contain the isotopic information of summer and winter feeding is a robust indicator for the annual mean proportion of maize in cattle diet on a farm. We could also demonstrate short term changes in the diet (when maize was added for some time) by comparing summer and winter $\delta^{13} \mathrm{C}$. Farms whose dietary proportion of maize deviated from the average dietary proportion of maize of the respective grazing regime (in summer or winter feeding) could be detected via the $\delta^{13} \mathrm{C}$ of a single cattle hair. We conclude that the method can be used in different cattle production systems to check on dietary proportions of maize for a period of one year before sampling of hair.

The third aim was to investigate the potentials and risks of land-use intensification on former extensively managed permanent grassland sites on sandy soils concerning productivity and other ecosystem services.

We set up a three-year field experiment with four management intensity levels representing four typical forage production systems (moderate permanent grassland, intensive permanent grassland, ley grass, maize) on five sites on a climatic gradient (temperature and precipitation) in northern Germany. We found that ley grass had no higher $\mathrm{N}$ yields and crude protein concentrations than intensive permanent grassland. Intensive permanent grassland had higher $\mathrm{N}$ yields than moderate permanent grassland while the number of plant species was not lower. Of all treatments, intensive permanent grassland was least influenced by site and year effects on yield, forage quality and species 
number. The dry matter yields of all grassland treatments were small, but forage had good net energy contents and crude protein concentrations. Dry matter yields of maize were in a range of those of the farming practice in the respective regions, but nutritional quality was poor. Maize showed a higher risk of nitrogen leaching compared to the grassland treatments. We conclude that to avoid a loss of ecosystem services and to have a forage production system that delivers yields of adequate quality, a moderate or intensive management of permanent grassland can be a good option on sandy soils.

\subsection{Zusammenfassung}

Grünland erfüllt eine Reihe von wichtigen Funktionen: Es liefert Biomasse für die Tierund Futtermittelproduktion und stellt gleichzeitig viele Ökosystemfunktionen, wie die Erhaltung der Artenvielfalt, Kohlenstoffspeicherung, Wasserreinigung, Nährstoffrückhaltung und einen hohen Erholungswert für die Gesellschaft, zur Verfügung. Diese Multifunktionalität hängt allerdings stark von der Bewirtschaftungsintensität und von verschiedenen Umweltbedingungen ab. Grünlandbewirtschaftung spielt eine wichtige Rolle innerhalb der landwirtschaftlichen Produktionssysteme in Deutschland, besonders in der Rinderhaltung. In Norddeutschland reicht der Anteil des Grünlandes an der gesamten landwirtschaftlichen Nutzfläche auf Landesebene von 20 bis über $30 \%$.

Die fortschreitende Intensivierung der Landnutzungssysteme mit immer höheren Anforderungen an die Milchleistungen pro Kuh führt zu einem immer höheren Bedarf an Energiegehalt im Tierfutter. Landwirte, die Grünland bewirtschaften, müssen sich diesem Trend anpassen um ihren Betrieb profitabel und wettbewerbsfähig zu erhalten. Diese Entwicklung führt zu einer Intensivierung der gesamten Futterproduktion. Für das Grünlandmanagement bedeutet dies höhere Stickstoffdüngergaben und eine erhöhte Nutzungsfrequenz. Es werden aber auch vermehrt Hochleistungsfuttermittel, insbesondere Mais, angebaut. Dies geschieht häufig auf Kosten von Dauergrünlandflächen. Da besonders extensiv bewirtschaftetes Dauergrünland neben der Produktionsfunktion sehr viele andere Ökosystemfunktionen bereitstellt, führt der Flächenverlust an Dauergrünland zu einer Schwächung der Multifunktionalität der Agrarlandschaft. 
Hinsichtlich dieser Ausgangssituation ging es im ersten Teil dieser Arbeit um die Einstellung und das Verhalten von Landwirten, die Grünland bewirtschaften, bezüglich der Agrarumweltmaßnahmen (AUM). Diese Maßnahmen wurden entwickelt, um eine extensive Bewirtschaftung von Dauergrünland zu fördern. Die Teilnahme an diesen Programmen ist freiwillig. Betriebe, die an AUM teilnehmen, bekommen staatliche Ausgleichszahlungen, wenn sie ihr Dauergrünland extensiv bewirtschaften. Innerhalb der Untersuchungen wurde ein standardisierter Fragebogen entwickelt, der von 82 Betriebsleitern von Grünland-Betrieben auf einem Gradienten von Westen nach Osten in Norddeutschland beantwortet wurde. Die Auswahl der Betriebe erfolge auf Basis von Zensus Daten, um ein repräsentatives Bild der Grünland-Betriebe der Untersuchungsregion zu bekommen. Es wurden Fragen zu persönlichen Daten, Betriebsund Geschäftsmanagement sowie $\mathrm{zu}$ allgemeinen landwirtschaftlichen und naturschutzfachlichen Angelegenheiten gestellt. Die Ergebnisse zeigen, dass die Mehrheit der befragten Betriebsleiter generell am Naturschutz interessiert ist. Die meisten Betriebsleiter vertraten die Ansicht, dass Landwirte die Aufgabe haben, die Natur aktiv zu schützen. Diese positive Einstellung zum Naturschutz korrelierte allerdings nicht mit einer positiven Einstellung zu AUM. Mit Hilfe des „farming style concepts“ wurden alle befragten Betriebsleiter in vier Gruppen eingeteilt (Traditionalisten, Idealisten, Modernisierer und Ertragsoptimierer). Diese Gruppen unterschieden sich hinsichtlich Betriebsparametern wie Betriebsgröße, der generellen Einstellung zu landwirtschaftlichen Belangen und wirtschaftlichem Erfolg. Es konnte gezeigt werden, dass sich diese vier Gruppen auch hinsichtlich ihrer Einstellung zum Naturschutz unterscheiden. Allerdings unterschieden sie sich nicht hinsichtlich der Nutzung von AUM und nannten zugleich unterschiedliche Gründe für eine Nichtteilnahme an den Maßnahmen. Die „farming styles“ beschreiben Landwirte auf Grund einer Kombination von Betriebsparametern und der Art wie diese Landwirte denken und fühlen. Für Beratungsstellen, die AUM in die landwirtschaftliche Praxis integrieren möchten, könnte eine Kommunikation, die an die unterschiedlichen „farming styles“ angepasst ist, von Vorteil sein. Die existierenden AUM sollten hinsichtlich der von den Betriebsleitern genannten Gründe für eine Nichtteilnahme überarbeitet werden.

Der zweite Teil dieser Arbeit befasst sich mit der Überprüfung der Praxistauglichkeit einer Methode zur Untersuchung des Maisanteils im Futter von unterschiedlichen Rinderhaltungssystemen. Die ${ }^{13} \mathrm{C}$-Isotopensignatur in den Rinderschwanzhaaren war Gegenstand dieser Untersuchungen. Rinderhaare fungieren als Archiv für 
Isotopensignaturen und erhalten somit Informationen über die Zusammensetzung des aufgenommen Futters in der Vergangenheit. In dieser Untersuchung wurde zunächst die Verlässlichkeit der ${ }^{13} \mathrm{C}$-Isotopensignatur in den Rinderschwanzhaaren für die Überprüfung des Maisanteils im Futter analysiert. Weiterhin wurde untersucht, ob der Maisanteil im Futter über einen längeren Zeitraum auf Basis eines einzelnen Haares zurückverfolgt werden kann, ohne kostspielige und zeitaufwendige Umfragen und Untersuchungen auf den Betrieben durchführen zu müssen. Es wurde untersucht, ob durch die Analyse von unterschiedlichen Abschnitte von Rinderschwanzhaare Unterschiede im Maisanteil im Futter während der Sommer- und der Winterfütterung festgestellt werden können. Auf 23 Rinderbetrieben in Norddeutschland wurden Rinderschwanzhaare und Informationen zum Management und der Futterzusammensetzung gesammelt. Die Betriebe unterschieden sich hinsichtlich des durchschnittlichen jährlichen Anteils von Mais, Gras und anderem Kraftfutter in der Ration und in der Haltungsform der Rinder (Ganzjahresweide, Weidehaltung im Sommer, keine Weidehaltung). Die Ergebnisse zeigen, dass die gemittelten ${ }^{13} \mathrm{C}$-Isotopensignaturen von zwei Haar-Abschnitten, welche isotopische Informationen über die Sommer und Winterfütterung enthalten, den durchschnittlichen jährlichen Maisanteil im Futter auf einem Betrieb verlässlich widerspiegeln. Kurzzeitige Änderungen in der Zusammensetzung der Ration (wenn über einen kurzen Zeitraum Mais gefüttert wurde) konnten ebenfallt aufgedeckt werden. Betriebe deren Maisanteil im Futter stark vom durchschnittlichen Maisanteil im Futter des jeweiligen Haltungssystems abwich, konnten ebenfalls mittels ${ }^{13} \mathrm{C}$-Isotopensignaturen in einem einzelnen Haar nachgewiesen werden. Demnach kann diese Methode in unterschiedlichen Rinderhaltungssystemen zur Überprüfung von Maisanteilen im Futter über einen Zeitraum von einem Jahr vor der Probenahme der Haare eingesetzt werden.

Der dritte Teil dieser Arbeit befasst sich mit der Untersuchung der Potentiale und Risiken einer Landnutzungsintensivierung von ehemals extensiv genutzten Dauergrünlandflächen auf sandigen Böden in Norddeutschland. In einer 3-Jahres-Studie wurden vier typische Futtermittelproduktionssysteme mit steigender Intensität (moderat bewirtschaftetes Dauergrünland, intensiv bewirtschaftetes Dauergrünland, Ackergras, Mais) auf fünf Untersuchungsstandorten auf einem Klimagradienten (Temperatur und Niederschlag) untersucht. In dieser Untersuchung konnten keine höhen Stickstofferträge und Rohproteingehalte im Ackergras im Vergleich zum intensiv bewirtschafteten Dauergrünland nachgewiesen werden. Das intensiv bewirtschaftete Dauergrünland zeigte 
allerdings im Vergleich zum moderat bewirtschafteten Dauergrünland höhere Stickstofferträge, Rohproteingehalte und Energiedichten im Aufwuchs. Die Anzahl der Pflanzenarten wurde allerdings durch diese Intensivierung nicht verringert. Im Vergleich zu den anderen drei Intensitätsstufen der Futtermittelproduktion wurde beim intensiv bewirtschafteten Dauergrünland am wenigsten Variabilität bei allen aufgenommenen Parametern zwischen den fünf Standorten und den drei Untersuchungsjahren festgestellt. Die Trockenmasseerträge der drei Grünland Intensitäts-Stufen waren gering aber von guter Qualität hinsichtlich Energie- und Rohproteingehalt. Die Trockenmasseerträge des Maises lagen im zu erwartenden Bereich für die Untersuchungsregion, waren aber von eher schlechter Qualität. Wie zu erwarten zeigte sich beim Mais ein höheres Risiko für eine Stickstoffauswaschung im Herbst im Vergleich zum Dauergrünland und zum Ackergras. Dies bedeutet, dass ein moderat bis intensiv bewirtschaftetes Dauergrünland eine akzeptable Option der Futtermittelproduktion auf ungünstigen Standorten darstellt. Der Verlust von wichtigen Ökosystemleistungen wird im Vergleich zum Ackergras und zum Mais vermindert und gleichzeitig kann eine angemessene Futterqualität erzielt werden. 



\section{CHAPTER 7}

Appendix 


\subsection{Index of Figures}

Fig.1.1: North German plain with the four NaLaMa-nT model regions

Diepholz, Uelzen, Fläming and Oder-Spree (right) and the geographical location in Germany.

Fig. 2.1: The North German Plain (NGP) within North European Plain (NEP) (left); and NGP with the four regions of this study (from west to east: Diepholz, Uelzen, Fläming, Oder-Spree) (right).

Fig. 2.2: Agreement of interviewed farmers to statements s26-s30 on nature conservation. Five-point Likert scale: $1=$ totally disagree, $5=$ totally agree.

Fig. 2.3: Agreement of interviewed farmers to statements s15-s20 on agrienvironment measures (AEM). Five-point Likert scale: $1=$ totally disagree, 5 $=$ totally agree.

Fig. 3.1: Scheme of cattle hair plucked on March 15, 2014 showing hair sections that were analyzed for the winter (light grey) and summer period (dark grey).

Fig. 3.2: Relationship between the annual mean dietary proportion of maize and the annual mean ${ }^{13} \mathrm{C}$ signature $\left({ }^{13} \mathrm{C}_{\text {Year }}\right)$ in cattle hair. Each point refers to a farm. The solid and dotted lines refer to regression line and $95 \%$ confidence interval respectively.

Fig. 3.3: Relationship of predicted and observed $\delta^{13} \mathrm{C}_{\text {Year }}$ with regression line and error bars for each farm.

Fig. 3.4: $\delta^{13} \mathrm{C}$ values of cattle hair sections analyzed seperately for summer and winter periods of the three grazing regimes $\left(\delta^{13} \mathrm{C}_{\text {Season }}\right)$. Annual dietary proportion (\%) of maize, grass and concentrates are indicated in the three boxes above each grazing regime. Circles indicate ourliers in the $\delta^{13} \mathrm{C}_{\text {Season }}$ value distributions within each season of each grazing regime.

Fig. 4.1: Relation of mean crude protein concentration and dry matter yields of all treatments in 2012-2014. PGM = moderate permanent grassland, PGI = intensive permanent grassland, Ley $=$ Ley grass, Maize $=$ Cultivation of maize.

Fig. 4.2: $\mathrm{N}$ yield in relation to the amount of annual $\mathrm{N}$ application on all treatments in 2012-2014. PGM = moderate permanent grassland, PGI = intensive permanent grassland Ley $=$ Ley grass, Maize $=$ Cultivation of maize . Letters A and B indicate significant differences $(\mathrm{p}<0.01)$ among treatments. 


\subsection{Index of Tables}

Tab. 1.1: Area of agricultural land and grassland in Germany (Source:

German Federal Statistical Office (Destatis), Subject-matter series 3, 2014).

Tab. 2.1: Some basic information about the model regions.

Tab. 2.2: Farm size, management and predominant grassland use of the 82 farms in the survey for the four model regions (regional means). LU/ha $=$ Livestock units per hectare, $\mathrm{N}=$ Nitrogen (from organic and artificial fertilizer).

Tab. 2.3: Degree of agreement to statement s15: "I try to use AEM as far as possible" of farmers differing in some personal or farm parameters.

Agreement on a Five-point Likert scale $(1=$ totally disagree, $5=$ totally agree).

Tab. 2.4: Differences between farmers that are using AEM and farmers that are not using AEM in degree of agreement to statements s15 and s27 (Degree of agreement on a Five-point Likert scale; $1=$ totally disagree, $5=$ totally agree) and in basic personal and farm data.

Tab. 2.5: Degree of agreement of farming styles to statements s27 and s15. Agreement on a Five-point Likert scale $(1=$ totally disagree, $5=$ totally agree) and percentage of farmers that actually use AEM.

Tab. 2.6: Reasons for non-participation in AEM mentioned by farmers during open conversations subsequent to our interview with the standardized questionnaire.

Tab. 3.1: Details of the production systems of cattle farms in the survey on a gradient from west to east. LU = livestock unit, $500 \mathrm{~kg}$ of body weight; Lon = Longitude.

Tab. 3.2: Recorded variables, source and range; DWD = Deutscher Wetter Dienst, German Weather Service.

Tab. 3.3: Correlation coefficients between $\delta^{13} \mathrm{C}_{\text {Year values of each farm and }}$ selected parameters of cattle production systems and location of the farms.

Tab. 4.1: Long-term temperature and precipitation dates on observation sites (arranged from west to east) among 1991-2010 and soil mean values (0-30 $\mathrm{cm}$ ) of Magnesium (Mg), Potassium (K), Phosphorus (P) (mg/100g) and $\mathrm{pH}-$ values of each site before staring the experiment.

Tab. 4.2: Experimental design.

Tab. 4.3: Results of ANOVA evaluating effects of Treatment, Site and Year on Yield, forage quality and other ecosystem service parameters. $* * *=\mathrm{p}<0.001 ; * *=\mathrm{p}<0.01$. 
Tab. 4.4: Differences in yield, forage quality and other ecosystem service parameters of treatments among years. Letters indicating significant differences among years (colums).

Tab. 4.5: Climatic parameters of all sites in all observation years. AMT = annual mean temperature, veg $\mathrm{T}=$ temperature during vegetation period.

Tab. 4.6: Differences in yield, forage quality and ecosystem service 64 parameters among treatments. $\mathrm{Sd}=$ Standard deviation. Letters indicating significant differences among treatments (rows).

* treatment was not included statistical analysis. 


\section{Acknowledgements}

Here I am, sitting at my desk and thinking about the meaning and the importance of the acknowledgements in a dissertation. I guess, I always think too much about the meaning and the importance of everything. All too often recently, the subject of my pondering has been life - as you image, piece of cake. So now, acknowledgements: When I want to thank people who have accompanied me during the last four years of my $\mathrm{PhD}$ thesis and during my study and during my life, people who helped me come so far - where do I start? Where do I stop? This decision is a bit like trying to figure out whom you want to invite to a party with a limited amount of beer or cake or space. However, being invited to a party is probably much nicer than being mentioned in the acknowledgements of a dissertation that will assumedly be only read by a small number of people. So maybe it is not important after all if I do or do not compose any acknowledgements. Perhaps I will be better off with revising the references again or going to the kitchen to cook something tasty (actually I am quite hungry). Well, of course there are three people who have to read this dissertation. And now when I think about them, I really get the feeling that it would not only be nice to thank them but that I really want to say thank you.

I thank Prof. Johannes Isselstein who gave me the opportunity to work on the NaLaMa-nT project and on this thesis and who always gave me excellent advice when needed.

Thanks to Prof. Nicole Wrage-Mönnig for great advice concerning the whole isotopic analysis-thing and for an open ear to discuss questions and ideas.

My special thanks go to Dr. Manfred Kayser for all the help, time and patience during the NaLaManT project and for teaching me so much; above all - writing science! It was inspiring to "grow up" under your advice - thank you very much indeed!

This actually feels kind of really nice. Now I come to think of it, there are some more people I would like to thank. Maybe they have the time and leisure to take a glimpse at my thesis or at least at these lines, which I dedicate to them.

I want to thank

Dr. Gesche Blume-Werry for staying so close although living so far away.

My beloved brother in spirit, Anna Brinkmann, for laughing, singing, climbing, philosophizing, crying and dancing with me.

The best flatmate on earth, Felix Wolking (who never got tired of arguing life, the universe and everything), for caring.

Hendrik Eckhardt - one of the most decent people I've ever met - for being a true friend!

And finally ("Never forget where you're coming from" - nicely phrased by a popular boy band from the '90s) I want to thank my parents Dorothea and Rüdiger Hammes who taught and gave me everything I needed -and more- to get by and make it in this weird world.

I guess acknowledgements are not so pointless after all. Even if only to remind you to appreciate support, reliability and friendship. This can never do any harm. Cheers! 


\section{E r k l är u n ge n}

1. Hiermit erkläre ich, dass diese Arbeit weder in gleicher noch in ähnlicher Form bereits anderen Prüfungsbehörden vorgelegen hat.

Weiter erkläre ich, dass ich mich an keiner anderen Hochschule um einen

Doktorgrad beworben habe.

Göttingen, den

(Unterschrift)

2. Hiermit erkläre ich eidesstattlich, dass diese Dissertation selbständig und ohne unerlaubte Hilfe angefertigt wurde.

Göttingen, den

(Unterschrift) 


\section{Verena Michaela Hammes}

\section{Personal details}

Date of birth 12.02.1986

Place of birth

Damme, Germany

Nationality

German

\section{Education}

Jan. 2013 - Dez. 2016

Oct. 2009 - Nov. 2011

Oct. 2006 - Aug. 2009

PhD Program for Agricultural Science

University of Goettingen

Master of Science „Biology”

University of Osnabrueck

Bachelor of Science „Landscape Ecology“,

University of Muenster

\section{Work experience}

Jan. 2013 - Dez. 2015

Project: "Sustainable land management in the North German Plain“ (NaLaMa-nT) Project leader of subproject L4: Grassland

Mai 2012 - Dez. 2012

Jan - Apr. 2012

Free-lancing worker for an environmental education center, Osnabrueck, Germany

Voluntary work on organic farms,

New Zealand

Aug. 2011

Student assistant and field assistant, University of Osnabrueck, Germany

Sep. 2008 - Sep.2009 Student assistant, University of Muenster, Germany

Jun. - Aug. 2008 Internship at the Musée national d'histoire naturelle - student assistant in a scientific research project, Luxembourg 